Prepared in cooperation with the Flood Control District of Maricopa County

\title{
Data from Channel-Change Monitoring at Selected Sites in Maricopa County, Arizona, 1997-2002
}

Open-File Report 2004-1230

U.S. Department of the Interior

U.S. Geological Survey 


\section{Data from Channel-Change Monitoring at Selected Sites in Maricopa County, Arizona, 1997-2002}

By Christie M. O'Day

Open-File Report 2004-1230 


\title{
U.S. Department of the Interior Gale A. Norton, Secretary
}

\author{
U.S. Geological Survey \\ Charles G. Groat, Director
}

\section{U.S. Geological Survey, Reston, Virginia: 2004}

For sale by U.S. Geological Survey, Information Services

Box 25286, Denver Federal Center

Denver, CO 80225-0286

For more information about the USGS and its products:

Telephone: 1-888-ASK-USGS

World Wide Web: http://www.usgs.gov/

Any use of trade, product, or firm names in this publication is for descriptive purposes only and does not imply endorsement by the U.S. Government.

Although this report is in the public domain, permission must be secured from the individual copyright owners to reproduce any copyrighted materials contained within this report.

Suggested citation:

O'Day, C.M., 2004, Data from channel-change monitoring at selected sites in Maricopa County, Arizona, 1997-2002: U.S.

Geological Survey Open-File Report 2004-1230, 52 p. 


\section{Contents}

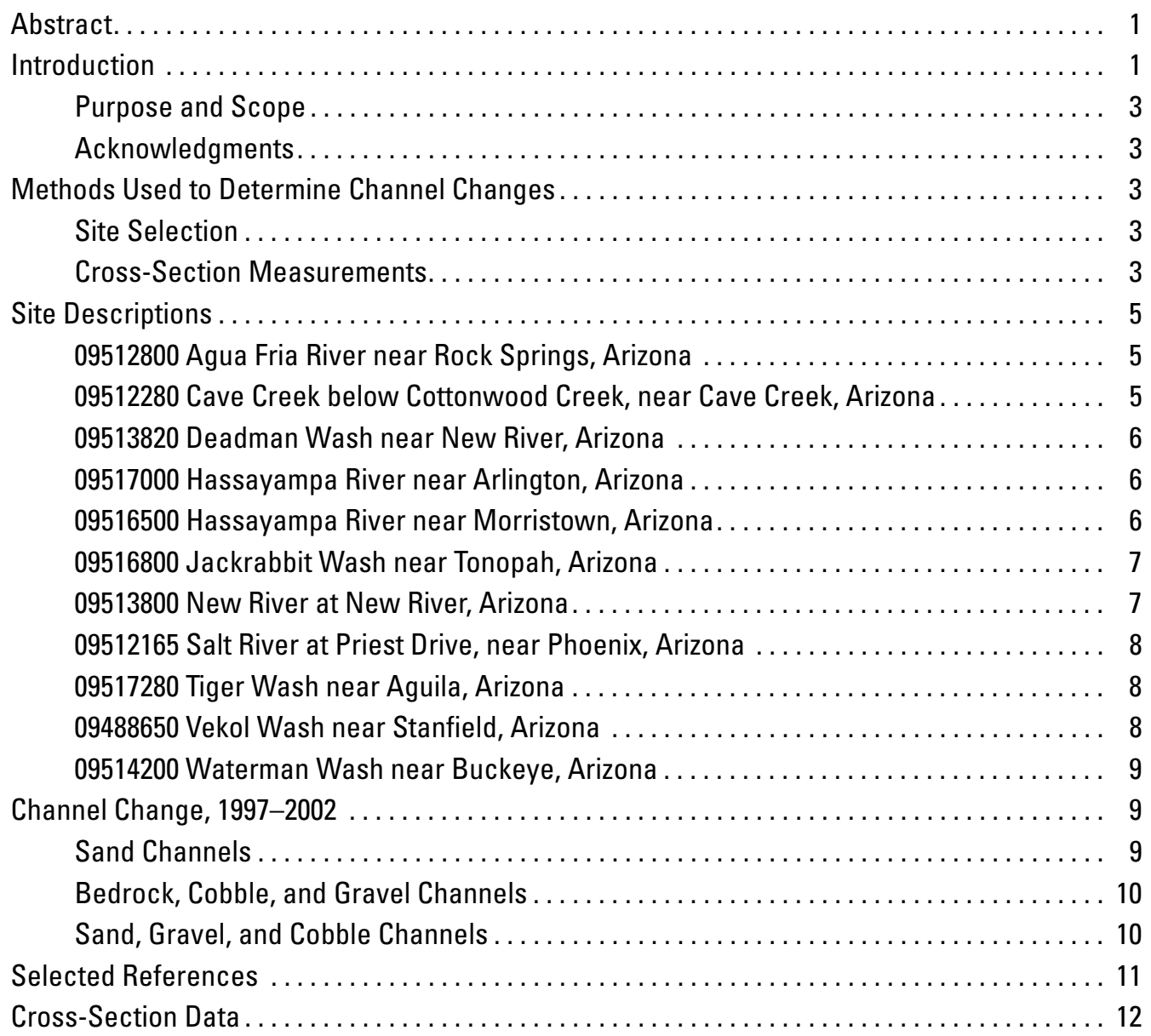




\section{Figures}

Figure 1. Map showing locations of study area and streamflow-gaging stations associated with channel-change monitoring sites, Maricopa County, Arizona ... 2

Figure 2. Channel-change cross sections from surveys at Agua Fria River near

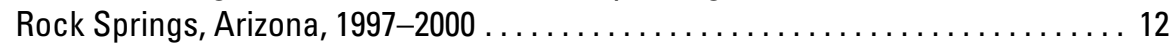

Figure 3. Channel-change cross sections from surveys at Cave Creek below

Cottonwood Creek, near Cave Creek, Arizona, 1997-99 ................... 16

Figure 4. Channel-change cross sections from surveys at Deadman Wash near

New River, Arizona, 1997-2000. ............................ 18

Figure 5. Channel-change cross sections from surveys at Hassayampa River near Arlington, Arizona, 1997-2000 ........................... 21

Figure 6. Channel-change cross sections from surveys at Hassayampa River near Morristown, Arizona, 1997-2001 ............................. 31

Figure 7. Channel-change cross sections from indirect-measurement surveys at Jackrabbit Wash near Tonopah, Arizona, 2000-2002 . ................ 34

Figure 8. Channel-change cross sections from surveys at New River at

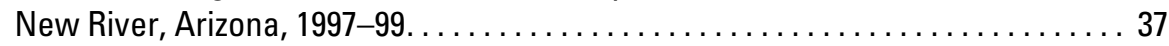

Figure 9. Channel-change cross sections from surveys at Salt River at

Priest Drive, near Phoenix, Arizona, 1997-99...................... 40

Figure 10. Channel-change cross sections from surveys at Tiger Wash

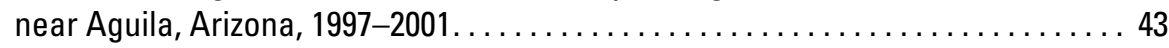

Figure 11. Channel-change cross sections from surveys at Vekol Wash near

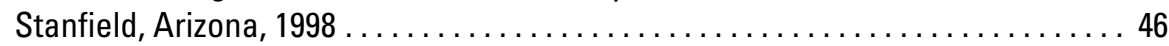

Figure 12. Channel-change cross sections from surveys at Waterman Wash near Buckeye, Arizona, 1997-2000 .............................. 49 


\section{Tables}

Table 1. Status summary for channel-change sites $\ldots \ldots \ldots \ldots \ldots \ldots \ldots \ldots \ldots$

Table 2. Data from surveys at Agua Fria River near Rock Springs, Arizona,

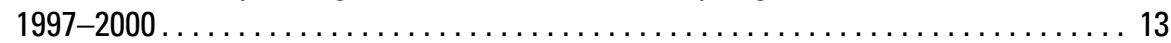

Table 3. Data from surveys at Cave Creek below Cottonwood Creek, near Cave Creek, Arizona, 1997-99............................. 16

Table 4. Data from surveys at Deadman Wash near New River, Arizona, 1997-2000 . . . . 19

Table 5. Data from surveys at Hassayampa River near Arlington, Arizona, 1997-2000 . . . . 23

Table 6. Data from surveys at Hassayampa River near Morristown, Arizona, 1997-2001 .. 32

Table 7. Data from indirect-measurement surveys at Jackrabbit Wash near Tonopah, Arizona, 2000-2002 ............................... 35

Table 8. Data from surveys at New River at New River, Arizona, 1997-99 . . . . . . . . . 38

Table 9. Data from surveys at Salt River at Priest Drive, near Phoenix,

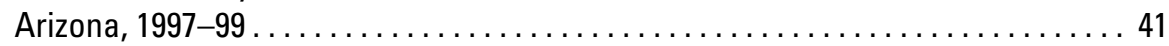

Table 10. Data from surveys at Tiger Wash near Aguila, Arizona, 1997-2001. . . . . . . . 44

Table 11. Data from surveys at Vekol Wash near Stanfield, Arizona, $1998 \ldots \ldots \ldots \ldots \ldots . .47$

Table 12. Data from surveys at Waterman Wash near Buckeye, Arizona, 1997-2000 . . . . . 50 


\section{Conversion Factors and Datums}

Conversion Factors

\begin{tabular}{rll}
\hline \multicolumn{1}{r}{ Multiply } & By & \multicolumn{1}{c}{ To obtain } \\
\hline foot (ft) & 0.3048 & meter \\
inch (in.) & 2.54 & centimeter \\
mile (mi) & 1.609 & kilometer \\
square mile $\left(\mathrm{mi}^{2}\right)$ & 2.590 & square kilometer \\
foot per second $(\mathrm{ft} / \mathrm{s})$ & 0.3048 & meter per second \\
cubic foot per second $\left(\mathrm{ft}^{3} / \mathrm{s}\right)$ & 0.02832 & cubic meter per second \\
\hline
\end{tabular}

Datums

Vertical coordinate information is referenced to the National Geodetic Vertical Datum of 1929 (NGVD of 1929) - a geodetic datum derived from a general adjustment of the first-order level nets of the United States and Canada, formerly called Sea Level Datum of 1929; horizontal coordinate information is referenced to the North American Datum of 1927 (NAD 27). 


\title{
Data from Channel-Change Monitoring at Selected Sites in Maricopa County, Arizona, 1997-2002
}

\author{
By Christie M. O'Day
}

\section{Abstract}

Stream channels in arid regions are subject to a wide range of hydrologic, hydraulic, and sedimentary conditions. These channels often are dry or have little streamflow most of the time, and the few flows that do occur can cause substantial changes to the channel and flood plain. Because floods in arid regions are often flashy, and many gaging stations are in remote areas, hydrographers must rely on indirect measurements of streamflow. Channel change is important because one major assumption necessary for indirect measurements of discharge is that the channel conditions after the flood represent the conditions during the peak discharge.

The U.S. Geological Survey, in cooperation with the Flood Control District of Maricopa County, is monitoring selected perennial and ephemeral streams within Maricopa County, Arizona, to track the amount and variability of channel change. This report contains basic data from surveys of monumented cross sections conducted from 1997 through 2002. The amount of change varied widely from channel to channel, and the largest geomorphic change occurred in conjunction with peak flows above the 10 -year recurrence interval.

\section{Introduction}

Stream channels in arid regions are subject to a wide range of hydrologic, hydraulic, and sedimentary conditions. These channels often are dry or have little or no streamflow but large magnitude flows can mobilize channel sediment and cause substantial changes to the channel and flood plain (Burkham, 1970; Graf, 1988).

Determining channel conditions in these regions during floods is difficult because of the dynamic nature of desert stream channels. Floods are often flashy, and many streamflow-gaging stations are in remote areas; therefore, hydrographers must rely on indirect measurements of discharge. One assumption necessary for indirect measurements of discharge is that the channel conditions after the flood represent the conditions during the peak discharge (Benson and Dalrymple, 1967). The errors associated with this assumption can be significant and limit the accuracy of indirect measurements of discharge (Jarrett, 1986).

Leopold and others (1964) state that in ephemeral washes and even large rivers in the semiarid West, channel scour increases as stage increases and can occur along the width of the channel. As the flood waters recede, however, sediment fills the scoured areas. Consequently, channel change is a source of error for indirect measurements of discharge. The relation between maximum scour depth and maximum discharge is not certain, and perceptions of scour may not equate to actual scour. Channel change depends on factors such as the chronology of flooding, the location of expansions and contractions in the channel, and the mobility of bed material (Jarrett, 1986).

In 1996, the U.S. Geological Survey (USGS), in cooperation with the Flood Control District of Maricopa County (FCDMC), established a network of sites on perennial and ephemeral streams in Maricopa County for long-term monitoring of channel change. Data from the monitoring program can be used to determine geomorphic changes, identify processes that could aid in developing predictive methodology, and determine rates of channel aggradation and degradation. Channel changes documented here are measured by repeated cross-section surveys with some repeat photography (not published in this report). An examination of channel changes helps to evaluate the accuracy of peakdischarge values from (1) indirect measurements of discharge and (2) rating curves based on indirect measurements of discharge and step-backwater models that assume a fixed channel geometry.

In the pilot part of this study, Capesius and Lehman (2002) reported on channel change for 10 sites on 7 perennial and ephemeral streams using historical cross-section data and data collected during 1996-97. The data-collection network has been revised for longer term monitoring and data analysis, and now consists of 11 sites on 10 streams (fig. 1). 


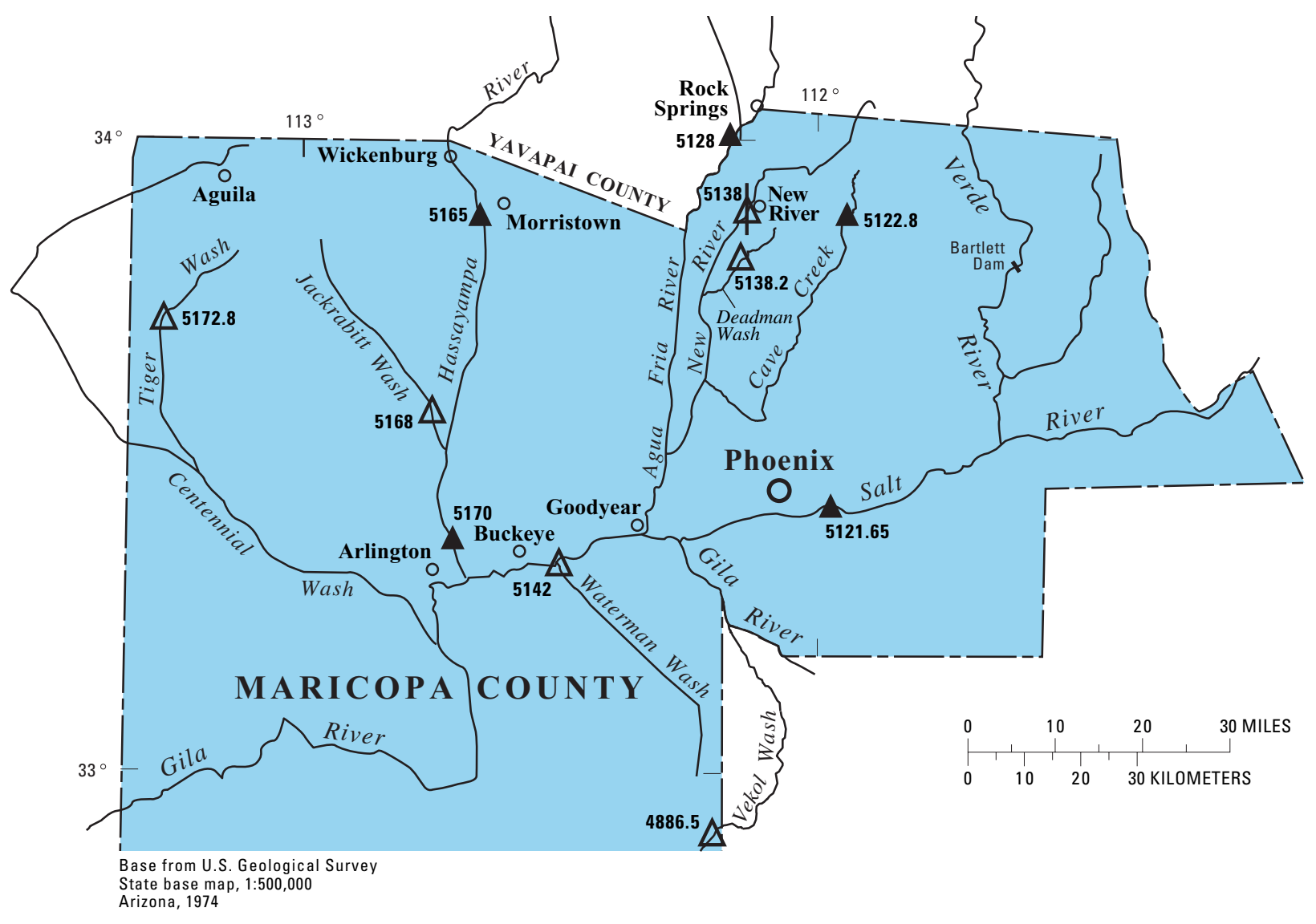

\section{EXPLANATION}

5170 CONTINUOUS StREAMFLOW-gaging STATION AND ABBREVIATED NUMBER Complete station number is 09517000

\section{STATION \\ NUMBER STATION NAME}

09512165 Salt River at Priest Drive near Phoenix, Arizona

09512280 Cave Creek below Cottonwood Creek, near Cave Creek, Arizona

$09512800 \quad$ Agua Fria River near Rock Springs, Arizona

$09516500 \quad$ Hassayampa River near Morristown, Arizona

5172.8

$09517000 \quad$ Hassayampa River near Arlington, Arizona

$\triangle$ CREST-StAge gaging StATION AND ABbREVIATED NUMBER Complete station number is 09517280

\section{STATION
NUMBER STATION NAME}

09488650 Vekol Wash near Stanfield, Arizona

09513820 Deadman Wash near New River, Arizona

$09514200 \quad$ Waterman Wash near Buckeye, Arizona

$09516800 \quad$ Jackrabbit Wash near Tonopah, Arizona

09517280 Tiger Wash near Aguila, Arizona

${ }^{5138} 4$ DiscontinUed U.S. GEOLOGICAL SURVEY Gaging STATION AND

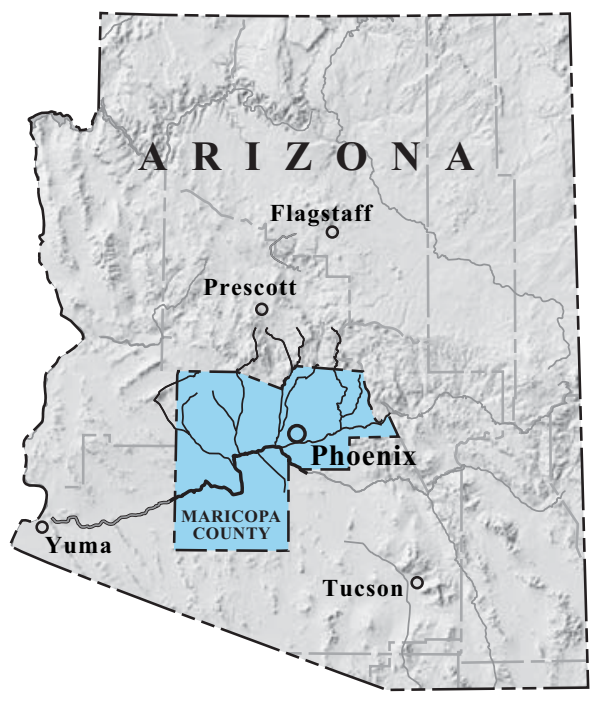

ABBREVIATED NUMBER - Complete station number is 09513800

STATION

NUMBER

STATION NAME

$09513800 \quad$ New River at New River, Arizona

Figure 1. Locations of study area and streamflow-gaging stations associated with channel-change monitoring sites, Maricopa County, Arizona. 


\section{Purpose and Scope}

This report presents data collected during repeat crosssection surveys and indirect measurements of discharge at the 11 sites from 1997 through 2002. Data were collected at sites for which long-term hydrologic records were available. Five sites are at USGS crest-stage gaging stations-Deadman Wash near New River, Jackrabbit Wash near Tonopah, Tiger Wash near Aguila, Vekol Wash near Stanfield, and Waterman Wash near Buckeye. Five sites are at continuous USGS streamflow-gaging stations-Agua Fria River near Rock Springs, Cave Creek below Cottonwood Creek, Hassayampa River near Arlington, Hassayampa River near Morristown, and Salt River at Priest Drive. The final site is at the location of a discontinued USGS gaging station-New River at New River.

\section{Acknowledgments}

Cindy Hayek, Barbara Wilson, Arthur Rees, and Frank Johnson, USGS, all assisted with field work. Dave Gardner, FCDMC, also gave much field assistance in resurveying as well as input on the report. Steve Wiele, USGS, provided helpful suggestions and focus. Wes Heaton, USGS, gave support and advice on surveying. John Parker, USGS, provided fieldnotes, guidance, and field assistance in recovering cross-section endpoints upstream of the gaging station at Hassayampa River near Arlington.

\section{Methods Used to Determine Channel Changes}

\section{Site Selection}

As part of the revisions to the monitoring network, 11 sites on 10 perennial and ephemeral rivers and washes within Maricopa County, Arizona, were selected for long-term monitoring of channel change. Criteria for site selection included known changes to channel geometry or characteristics, streamflow records that exceeded 20 years, several

measurements of high discharge during the same flood, mobile channels, and previously monitored cross sections. One of the 11 sites, Salt River at Priest Drive, was discontinued in 2000 after the FCDMC began grading the river channel in order to mitigate vegetation growth.

\section{Cross-Section Measurements}

Surveying method and frequency.-After site selection, existing historical cross-section data were examined, including those from current-meter and indirect measurements of discharge. Monumented cross sections at Hassayampa River near Arlington (Parker, 1995) also were resurveyed. All cross sections are resurveyed after every flow that exceeds the 2-year recurrence interval as determined by Pope and others (1998) or calculated using the USGS statistical program, PEAKFQ (Kirby, 1981). Flow data and flood intervals for all selected sites are summarized in table 1.

During dry cycles, such as the one in effect for the past 3 years (2000-2002) cross sections are resurveyed approximately every 3 to 5 years. All surveys were done by a two-person crew using a Ziess level or Nikon total station and standard USGS surveying techniques, with the exception of the 2000 and 2002 Jackrabbit Wash surveys that were done as indirect measurements of discharge.

Cross sections measured for this study. - Data from crosssection surveys during 1997-2002 are presented in tables 2-12 (at back of report). There were no resurveys for most of 2002 because of drought conditions that dominated the region until September 2002. The initial survey conducted at Jackrabbit Wash in 1997 has not been included because all but three endpoints were lost in the peak-of-record flow in 2000. Survey data were plotted to illustrate cross-section changes through time in figures 2-12 (at back of report). Graphical representations of cross sections in this report are oriented so that the view is downstream and the left bank appears on the left side of the graph. Two elevations were recorded for some endpoints. These represent the base (ground level) and the top of the rebar or other endpoint marker. Numbering of some of the cross sections is based on the pilot study by Capesius and Lehman (2002) and the cross-section sequence does not always start at " $1 . "$

The given elevation used to determine the geometry of a cross section is called the relative elevation in this study. At each site, a local elevation datum is used to compare channel change in nearby cross sections. This elevation is either gage datum or zero for all sites, except for Hassayampa River near Arlington, for which the elevation from the 1992 survey (Parker, 1995) was used. This methodology focuses on the relative changes in the cross sections through time. Cross-section measurement dates are given for each site. The change in cross-sectional area was computed using the original measured cross section (usually from 1997 or 1998) as the base. A positive change in crosssectional area represents an increase in cross-sectional area, and therefore scour, and a negative change represents a decrease in cross-sectional area, and therefore fill. 


\section{Data from Channel-Change Monitoring at Selected Sites in Maricopa County, Arizona, 1997-2002}

Table 1. Status summary for channel-change sites

[Values for 2- and 10-year recurrence interval floods are from Pope and others (1998), except for stations 09512280 and 09488650, which are from Blakemore Thomas (hydrologist, U.S. Geological Survey, written commun., 2004). $\mathrm{ft}^{3} / \mathrm{s}$, cubic feet per second; <, less than; NA, not available]

\begin{tabular}{|c|c|c|c|c|c|c|c|c|c|}
\hline Site name and No. & $\begin{array}{l}\text { Number } \\
\text { of cross } \\
\text { sections }\end{array}$ & \multicolumn{5}{|c|}{ Peak discharge by water year $\left(\mathrm{ft}^{3} / \mathrm{s}\right)$} & \multicolumn{2}{|c|}{$\begin{array}{l}\text { Discharge of } \\
\text { recurrence interval } \\
\text { flood }\left(\mathrm{ft}^{3} / \mathrm{s}\right)\end{array}$} & Date of last survey \\
\hline $\begin{array}{l}\text { Agua Fria River near Rock Springs, } \\
09512800^{1}\end{array}$ & 4 & 10,400 & 4,830 & 8,230 & 5640 & 7,420 & 7,000 & 44,300 & Sept. 11, 2000 \\
\hline Deadman Wash near New River, 09513820 & 6 & 489 & 467 & 769 & 714 & 511 & 348 & 1,590 & Dec. 19,2000 \\
\hline $\begin{array}{l}\text { Hassayampa River near Arlington, } \\
09517000^{1}\end{array}$ & 11 & 396 & 3,310 & 4,480 & 22,200 & 3,930 & 3,010 & 12,000 & $\begin{array}{l}\text { Nov. } 20-21,2000 \\
\text { Nov. } 30,2000\end{array}$ \\
\hline $\begin{array}{l}\text { Hassayampa River near Morristown, } \\
09516500^{1}\end{array}$ & 4 & 594 & 2,710 & 4,700 & 13,400 & 6,040 & 3,030 & 14,300 & Feb. 6, 2001 \\
\hline $\begin{array}{l}\text { Salt River at Priest Drive, near Phoenix, } \\
\quad 09512165^{1}\end{array}$ & 4 & 7,580 & 584 & 567 & $\left({ }^{3}\right)$ & $\left({ }^{3}\right)$ & NA & NA & $\begin{array}{l}\text { Nov. 19, 1999; } \\
\text { Nov. 22, } 1999\end{array}$ \\
\hline Tiger Wash near Aguila, 09517280 & 4 & 683 & 755 & 2,490 & 3,850 & 5,184 & 961 & 3,160 & Apr. 6, 2001 \\
\hline Vekol Wash near Stanfield, 09488650 & 5 & 1,100 & 481 & 294 & 347 & 602 & 780 & 4,400 & Oct. 28,1998 \\
\hline Waterman Wash near Buckeye, 09514200 & 7 & 325 & 916 & no flow & 3,650 & 72 & 1,250 & 3,420 & Dec. $20-21,2000$ \\
\hline
\end{tabular}

${ }^{1}$ Station equipped with continuous stage recorder or located near station equipped with continuous stage recorder.

${ }^{2}$ Discharge information from 09513780, New River near Rock Springs, 10 mi upstream.

${ }^{3}$ Discontinued monitoring site in 2000 .

Indirect measurement of discharge. - Indirect measurements of discharge frequently are made to determine peak discharge and are especially important at sites where direct measurements of discharge are difficult to obtain. Indirect methods use channel characteristics, such as resistance to flow or roughness, channel geometry or cross sections, slope, and water-surface profile as determined by high-water marks, to determine discharge (Dalrymple and Benson, 1967). This report incorporates cross sections surveyed as part of indirect measurements.
Indirect measurements of discharge can be computed using several different methods. Three USGS accepted methods are (1) slope-conveyance computation, (2) slope-area computation, and (3) step-backwater analysis. Of the three, the slope-area method is most frequently used (Dalrymple and Benson, 1967). Two slope-area measurements were done at Jackrabbit Wash near Tonopah in 2000 and 2002. 


\section{Site Descriptions}

Initially, 11 channel-change sites were selected for monitoring in 1997-98. Salt River at Priest Drive was discontinued in 2000 after Maricopa County graded the channelized river bed in order to mitigate vegetation growth. Because channel variations in this section of the Salt River would result directly or indirectly from alterations by humans, the site was no longer included in the study. The following section presents detailed descriptions of each channel-change site. Longitudinal distance between end points is provided for the sites where surveying was done with a Nikon total station.

\section{Agua Fria River near Rock Springs, Arizona}

Reach location-The channel-change monitoring reach extends from $390 \mathrm{ft}$ upstream from the streamflowgaging station, Agua Fria River near Rock Springs, to $670 \mathrm{ft}$ downstream. The gaging station is at latitude $34^{\circ} 00^{\prime} 56^{\prime \prime N}$., longitude $112^{\circ} 10^{\prime} 02^{\prime \prime W}$., in NW1/4 sec. 28 , T. 8 N., R. 2 E., Yavapai County, on right bank $2.5 \mathrm{mi}$ southwest of Rock Springs, 10 mi upstream from Lake Pleasant, and 45 mi north of Phoenix. Black Canyon City 7.5-minute quadrangle. There are two crest-stage gages near the staff gages at the main gaging station. Pin elevations (gage datum) are $9.377 \mathrm{ft}$ and $14.876 \mathrm{ft}$ from levels of June 12, 1997.

Drainage area-1,111 $\mathrm{mi}^{2}$.

Channel description-Although Agua Fria River near Rock Springs has a large drainage area, it usually has a small base flow. Channel alluvium primarily is coarse gravel but ranges in size from boulders to silt. Outcrops of bedrock restrict lateral movement of the stream channel at the gaging station. At cross-section 1, the left bank (approximately $100 \mathrm{ft}$ downstream from the old cableway cross section) is a bedrock cliff, and the right bank is on the inside of a bend in the channel, which is unconsolidated alluvium. At sections 2-4, the right bank is bedrock and consolidated alluvium, and the left bank is a flood terrace.

Most recent survey-September 11, 2000.

Cross-section locations-

Cross-section 1 is $390 \mathrm{ft}$ upstream from gaging station. The left endpoint is a painted yellow dot on a rock outcrop (hard to recover) and the right endpoint is rebar in sand.

Cross-section 2 is at gaging station. The left endpoint is rebar on downstream side of the access road, on hill, and the right endpoint is the lower crest-stage gage pin above orifice line (also can use upper crest-stage gage pin).

Cross-section 3 is $400 \mathrm{ft}$ downstream from gaging station. The left endpoint is rebar on first flood terrace, and the right endpoint is a yellow mark on rock (unrecoverable in 2000).
Cross-section 4 is $670 \mathrm{ft}$ downstream from gaging station. As with cross-section 3, the left endpoint is rebar on flood terrace, and right endpoint is yellow mark on rock (unrecoverable in 2000).

\begin{tabular}{ccccccc}
\hline \multicolumn{4}{c}{ Distance between cross-section endpoints, in feet } \\
\hline \multicolumn{2}{c}{ Cross section along left bank } & & \multicolumn{3}{c}{ Cross section along right bank } \\
\cline { 1 - 2 } \cline { 5 - 7 } $\mathbf{1 - 2}$ & $\mathbf{2 - 3}$ & $\mathbf{3 - 4}$ & & $\mathbf{1 - 2}$ & $\mathbf{2 - 3}$ & $\mathbf{3 - 4}$ \\
\hline 387 & 398 & 267 & & 501 & 314 & 310 \\
\hline
\end{tabular}

\section{Cave Creek below Cottonwood Creek, near Cave Creek, Arizona}

Reach location-The channel-change monitoring reach extends from 150 to $750 \mathrm{ft}$ upstream from the streamflow-gaging station, Cave Creek below Cottonwood Creek, near Cave Creek. The gaging station is at latitude $33^{\circ} 53^{\prime} 14^{\prime \prime N}$., longitude $111^{\circ} 57^{\prime} 12^{\prime \prime W}$., in SE1/4SE1/4SW1/4, sec. 4, T. 6 N., R. 4 E., Maricopa County, on left bank 1,500 ft downstream from Cottonwood Creek and 3.7 mi north of town of Cave Creek. Datum of gaging station is 2,280 ft above NGVD of 1929, from topographic map.

Drainage area- $82.7 \mathrm{mi}^{2}$.

Channel description-The channel is cobble and gravel, and is fairly straight throughout the study reach. The channel contracts from the road crossing just downstream from cross-section 6 through cross-section 3. The gaging station orifice is on a rock outcrop composed of conglomerated boulders and cobbles about $150 \mathrm{ft}$ downstream from cross-section 3. The left bank is approximately $20 \mathrm{ft}$ high and is nearly vertical at the gaging station but decreases in height upstream. The right bank is 5-7 ft high, slopes gently, and is vegetated with palo verde trees, mesquite trees, Johnson grass, and large saguaros. It is subject to overflow during high flows.

Most recent survey-August 10, 1999.

Cross-section locations-Most of the right endpoints are near prominent saguaros. All endpoints are rebar. There are no cross-sections 1 and 2 .

Cross-section 3 is about $150 \mathrm{ft}$ upstream from gaging station.

Cross-section 4 is about $350 \mathrm{ft}$ upstream from gaging station and $200 \mathrm{ft}$ upstream from cross-section 3.

Cross-section 5 is about $550 \mathrm{ft}$ upstream from gaging station and $200 \mathrm{ft}$ upstream from cross-section 4.

Cross-section 6 is about $750 \mathrm{ft}$ upstream from gaging station and $200 \mathrm{ft}$ upstream from cross-section 5 . 


\section{Deadman Wash near New River, Arizona}

Reach location-The channel-change monitoring reach extends from $70 \mathrm{ft}$ upstream from two crest-stage gages to $600 \mathrm{ft}$ downstream. The crest-stage gages are at latitude $33^{\circ} 50^{\prime} 30^{\prime \prime} \mathrm{N}$., longitude $112^{\circ} 08^{\prime} 40^{\prime \prime} \mathrm{W}$., in NW1/4 sec. 27, T. 6 N., R. 2 E., Maricopa County, $300 \mathrm{ft}$ west of Interstate 17 bridge, $4.5 \mathrm{mi}$ south of New River. Datum of gaging station is $1,719.19 \mathrm{ft}$ above NGVD of 1929 .

Drainage area- $11.1 \mathrm{mi}^{2}$.

Channel description-The channel is hour-glass shaped and the narrowest point is near cross-section 3 where the channel is constricted by steep, high banks, less than 50 $\mathrm{ft}$ across. Otherwise the channel banks are gently sloping, 4 to $6 \mathrm{ft}$ high, and covered by brush and trees. The banks are subject to overflow during high flows. The channel bed is composed of cobbles and boulders with some gravel downstream from the road.

Most recent survey-December 19, 2000.

Cross-section locations-All endpoints are rebar. Crosssection 4 was not resurveyed. Cross-section 3 was added in 1998.

Cross-section 1 is $70 \mathrm{ft}$ upstream from the crest-stage gages.

Cross-section 2 is at the crest-stage gages.

Cross-section 3 is about $200 \mathrm{ft}$ downstream from the crest-stage gages.

Cross-section 4 is at road crossing, about $400 \mathrm{ft}$ downstream from the crest-stage gages and is subject to road grading.

Cross-section 5 is $100 \mathrm{ft}$ downstream from road crossing, $500 \mathrm{ft}$ downstream from the crest-stage gages.

Cross-section 6 is $200 \mathrm{ft}$ downstream from road crossing, $600 \mathrm{ft}$ downstream from the crest-stage gages.

\section{Hassayampa River near Arlington, Arizona}

Reach location-The channel-change monitoring reach is about 3,000 ft upstream from the streamflow-gaging station, Hassayampa River near Arlington, and is immediately downstream from the Southern Pacific Railroad bridge. Monumented cross sections installed and surveyed by Parker (1995) are being monitored and resurveyed for the current study. The gaging station, latitude $33^{\circ} 20^{\prime} 50^{\prime \prime} \mathrm{N}$., longitude $112^{\circ} 43^{\prime} 30^{\prime \prime} \mathrm{W}$., is on upstream side of bridge on Old U.S. Highway 80, $0.2 \mathrm{mi}$ east of the Hassayampa Store, $1.8 \mathrm{mi}$ upstream from the mouth, and $2.8 \mathrm{mi}$ northeast of Arlington. Datum of the gage is $824.75 \mathrm{ft}$ above NGVD of 1929 .

Drainage area-1,471 $\mathrm{mi}^{2}$.
Channel description-The river has entrenched into the alluvial valley fill. The main flow path is wide and shallow and is composed primarily of sand, silt, and local deposits of gravel. Within the main channel, there is an unvegetated low-flow channel. The areas above the lowflow channel, which constitute the flood plain, are covered with scattered tamarisk, palo verde, and other bushes and shrubs. The left bank is a man-made levee, and the right bank is the first flood terrace.

Most recent survey-November 20-21 and 30, 2000

Cross-section locations-All cross sections used were established in 1991-92 by Parker (1995). Sections start just downstream from the railroad bridge, beginning with cross-section 1, and are numbered consecutively downstream to cross-section 11. Both endpoints for cross-section 8 were unrecoverable in 2000, so crosssection 8 was dropped from survey. All left-bank endpoints are on man-made levee, and all endpoints are rebar except for cross-section 3 and 5 right-bank endpoints, which are wooden stakes.

\begin{tabular}{ccccccccc}
\hline \multicolumn{1}{c}{ Distance between cross-section endpoints along left bank, in feet } \\
\hline $\mathbf{1 - 2}$ & $\mathbf{2 - 3}$ & $\mathbf{3 - 4}$ & $\mathbf{4 - 5}$ & $\mathbf{5 - 6}$ & $\mathbf{6 - 7}$ & $\mathbf{7 - 9}$ & $\mathbf{9 - 1 0}$ & $\mathbf{1 0 - 1 1}$ \\
\hline 27 & 126 & 233 & 154 & 220 & 198 & 555 & 349 & 177 \\
\hline
\end{tabular}

Distance between cross-section endpoints along right bank, in feet

\begin{tabular}{rrrrrrrrr}
\hline $\mathbf{1 - 2}$ & $\mathbf{2 - 3}$ & $\mathbf{3 - 4}$ & $\mathbf{4 - 5}$ & $\mathbf{5 - 6}$ & $\mathbf{6 - 7}$ & $\mathbf{7 - 9}$ & $\mathbf{9 - 1 0}$ & $\mathbf{1 0 - 1 1}$ \\
\hline 186 & 140 & 280 & 286 & 181 & 272 & 820 & 302 & 132 \\
\hline
\end{tabular}

\section{Hassayampa River near Morristown, Arizona}

Reach location-The channel-change monitoring reach extends from about $780 \mathrm{ft}$ upstream from the streamflowgaging station, Hassayampa River near Morristown, to $330 \mathrm{ft}$ downstream. The gaging station is at latitude $33^{\circ} 53^{\prime} 06^{\prime \prime}$., longitude $112^{\circ} 39^{\prime} 41^{\prime \prime W}$., on the left bank, $600 \mathrm{ft}$ downstream from the mouth of San Domingo Wash, Maricopa County, 3 mi northwest of Morristown and 6 mi southeast of Wickenburg, Arizona. Datum of the gaging station is $1,831.16 \mathrm{ft}$ above NGVD of 1929 .

Drainage area-796 $\mathrm{mi}^{2}$.

Channel description-The gaging station at Hassayampa River near Morristown is attached to a bedrock cliff on the left bank. The bedrock cliffs start at the confluence of San Domingo Wash, between cross-sections 1 and 2, and continue downstream past cross-section 4 . At crosssection 1, the left bank is the highway embankment. The right bank is a railroad embankment blasted into bedrock and consolidated alluvium. The flat, sand channel narrows in the downstream direction toward the gaging station.

Most recent survey-February 6, 2001. 


\section{Cross-section locations-}

Cross-section 1 is upstream from a fence crossing the channel upstream about $150 \mathrm{ft}$ from where the San Domingo Wash enters the Hassayampa. Upper left endpoint is concrete pad of fence post at the top of the embankment, under a large mesquite tree. Upper right endpoint is railway caution sign, set on far side of tracks. Lower or common right endpoint is top of sunken, wooden fence post, $8 \times 8$ in.

Cross-section 2 is $454 \mathrm{ft}$ upstream from cableway (about $50 \mathrm{ft}$ downstream from San Domingo Wash). Left endpoint is bolt on rock, right endpoint is rebar at top of railway embankment.

Cross-section 3 is directly under the cableway. Left endpoint is USGS brass tablet RM-3. Right endpoint was not established, used cable anchor footing.

Cross-section 4 is $327 \mathrm{ft}$ downstream from cableway. Left endpoint is white dot on rock. Right endpoint is top of headwall of culvert.

\section{Jackrabbit Wash near Tonopah, Arizona}

Reach location-Slope-area reach extends from about $400 \mathrm{ft}$ downstream from two crest-stage gages to about $1,500 \mathrm{ft}$ downstream. The crest-stage gages are at latitude $33^{\circ} 39^{\prime} 32^{\prime \prime N}$., longitude $112^{\circ} 49^{\prime} 40^{\prime \prime} \mathrm{W}$., in NE1/4NW1/4 sec. 25, T. 4 N., R. 6 W., Maricopa County, 35 ft downstream from the Wickenburg Road crossing, $5.3 \mathrm{mi}$ southeast of Baine Corners, and 14 mi northeast of Tonopah. Datum of gage is 1,510 ft above NGVD of 1929 from Star Well 7.5-minute quadrangle.

Drainage area-137 $\mathrm{mi}^{2}$.

Channel description - The channel is wide, mostly sand, but also includes gravel and small cobbles. The low-flow channel shifts across this channel bottom. The channel banks are steep, entrenched into semiconsolidated alluvium, and vegetated on both sides. The banks consist of two flood terraces. Cross-section endpoints were originally set on the first terrace and most were washed away in the peak-of-record flow in October 2000.

Most recent survey_-Indirect measurement, October 2002.

Cross-section locations - Original cross sections were approximately $200 \mathrm{ft}$ apart, starting about $100 \mathrm{ft}$ downstream from the crest-stage gages; however, all but three of the endpoints were lost in a peak-of-record flow in October 2000. New cross sections were established during indirect measurement surveys conducted in 2000 and 2002. Both surveys incorporated the remaining original endpoints.

Cross-section 1 is about $400 \mathrm{ft}$ downstream from the crest-stage gages.
Cross-section 2 is about $700 \mathrm{ft}$ downstream from the crest-stage gages.

Cross-section 3 is about 1,000 ft downstream from the crest-stage gages.

Cross-section 4 is about 1,250 $\mathrm{ft}$ downstream from the crest-stage gages.

Cross-section 5 is about 1,500 $\mathrm{ft}$ downstream from the crest-stage gages.

\begin{tabular}{cccc}
\hline \multicolumn{4}{c}{ Distance between cross-section endpoints along left bank, in feet } \\
\hline $\mathbf{1 - 2}$ & $\mathbf{2 - 3}$ & $\mathbf{3 - 4}$ & $\mathbf{4 - 5}$ \\
\hline 310 & 285 & 210 & 325 \\
\hline
\end{tabular}

Distance between cross-section endpoints along right bank, in feet

\begin{tabular}{rrrl}
\hline $\mathbf{1 - 2}$ & $\mathbf{2 - 3}$ & $\mathbf{3 - 4}$ & $\mathbf{4 - 5}$ \\
\hline 340 & 420 & 270 & 130 \\
\hline
\end{tabular}

\section{New River at New River, Arizona}

Reach location-The channel-change monitoring reach extends from about $200 \mathrm{ft}$ upstream from an old cableway to $240 \mathrm{ft}$ downstream. The discontinued streamflowgaging station, New River at New River, was about $500 \mathrm{ft}$ downstream from the end of the cross-section reach. There is currently no active gage at this site. The gaging station was at latitude $33^{\circ} 54^{\prime} 41^{\prime \prime} \mathrm{N}$., longitude $112^{\circ} 08^{\prime} 26^{\prime \prime W}$., in $\mathrm{NW}^{1} 1 / 4 \mathrm{NE}^{1} / 4$, sec. 34, T. 7 N., R. 2 E., near center of downstream side of bridge on east frontage road of Interstate 17, $0.5 \mathrm{mi}$ southwest of the town of New River, and 10 mi south of Rock Springs.

Drainage area- $83.3 \mathrm{mi}^{2}$.

Channel description-Channel is straight for about $300 \mathrm{ft}$ upstream and $150 \mathrm{ft}$ downstream from the abandoned cableway and consists mainly of sand, gravel, and boulders. The left bank is consolidated to semiconsolidated alluvium overgrown by grass and brush, and the right bank is bedrock covered with alluvium and large boulders.

Most recent survey-March 11-12, 1999.

Cross-section locations-All cross sections surveyed in 1997 were unrecoverable in 1999 and were reestablished using original survey data and photographs. There are no crosssections 1 and 2.

Cross-section 3 is about $200 \mathrm{ft}$ upstream from old cableway, endpoints are rebar.

Cross-section 4 is under old cableway, left bank endpoint is on A-frame.

Cross-section 5 is about $240 \mathrm{ft}$ downstream from old cableway along road crossing the river bed, endpoints are rebar. 


\section{Salt River at Priest Drive, near Phoenix, Arizona}

Reach location-The channel-change monitoring reach extended from about $750 \mathrm{ft}$ upstream from the streamflow-gaging station to about $1,750 \mathrm{ft}$ downstream. The gaging station is at latitude $33^{\circ} 26^{\prime} 22^{\prime \prime} \mathrm{N}$., longitude $111^{\circ} 57^{\prime} 37^{\prime \prime W}$., in $\mathrm{NE}^{1 / 4 \mathrm{NE}^{1} / 4}$ sec. 17 , T. 1 N., R. 4 E., Maricopa County, on downstream side of the Priest Drive bridge. Elevation of gage is $1,135 \mathrm{ft}$ above NGVD of 1929 from topographic map. This reach was dropped from the monitoring schedule in 2000.

Drainage area-13,223 $\mathrm{mi}^{2}$.

Channel description-The channel is approximately $1,000 \mathrm{ft}$ wide and consists of bedrock and overlying bars of boulders, cobbles, and sand. It is virtually straight for 1 mi upstream and $1 \mathrm{mi}$ downstream from the gaging station. Both right and left banks are man-made levees, and the whole channel was graded by the FCDMC for vegetation mitigation in 2000. Low flows are braided between exposed bedrock and cobble bars.

Most recent survey-November 19 and 22, 1999.

Cross-section locations-Endpoints are spots of paint on top of channelized banks.

Cross-section 1 is about $750 \mathrm{ft}$ upstream from the gaging station.

Cross-section 2 is in line with gaging station, on the downstream side of the Priest Drive bridge.

Cross-section 3 is about $620 \mathrm{ft}$ downstream from the bridge.

Cross-section 4 is about 1,130 ft downstream from cross-section 3.

\section{Tiger Wash near Aguila, Arizona}

Reach location-The channel-change monitoring reach extends from $350 \mathrm{ft}$ upstream from a series of crest-stage gages to about $450 \mathrm{ft}$ downstream. The crest-stage gages are at latitude $33^{\circ} 44^{\prime} 30^{\prime \prime} \mathrm{N}$., longitude $113^{\circ} 16^{\prime} 43^{\prime \prime} \mathrm{W}$., in SW1/4SW11/4 sec. 26, T. 5 N., R. 10 W., Maricopa County, about 0.2 mi southeast of Eagle Eye Road, 17 mi south of Aguila, and $10 \mathrm{mi}$ north of the junction of Eagle Eye Road and Buckeye-Salome Road. Datum of the gages is $1,870 \mathrm{ft}$ above NGVD of 1929 from Weldon Hill 7.5minute quadrangle.

Drainage area- $-85.2 \mathrm{mi}^{2}$.

Channel description-The stream channel is primarily sand and gravel and includes scattered large boulders.

Vegetation is moderate, with large bushes growing in the channel near the margins. At low to medium stages, flow is confined to the flat, sandy main channel. At higher stages, the overflow channel, which is on the right side of the main channel and is heavily vegetated, becomes effective. The left bank is confined by bedrock outcrops, and the right bank is the flood terrace.

Most recent survey-April 6, 2001.

Cross-section locations-

Cross-section 1 is $350 \mathrm{ft}$ upstream from the crest-stage gage, left endpoint is yellow paint mark on rock outcrop, right endpoint is wooden stake.

Cross-section 2 is at the crest-stage gage, initial survey after 1997 indirect measurement.

Cross-section 3 is $195 \mathrm{ft}$ downstream from the creststage gage, left endpoint is wooden stake, right endpoint is rebar.

Cross-section 4 is $446 \mathrm{ft}$ downstream from the creststage gage. Original left endpoint was yellow " $\mathrm{X}$ " on rock, current left endpoint is wooden stake, right endpoint is wooden stake.

\section{Vekol Wash near Stanfield, Arizona}

Reach location-The channel-change monitoring reach extends from about $400 \mathrm{ft}$ upstream from a crest-stage gage to about $400 \mathrm{ft}$ downstream. The crest-stage gage is at latitude $32^{\circ} 50^{\prime} 30^{\prime \prime} \mathrm{N}$., longitude $112^{\circ} 15^{\prime} 04^{\prime \prime} \mathrm{W}$., in SW $1 / 4$ SW $1 / 4$ sec. 3, T. 7 S., R. 1 E., Maricopa County, on the left bank, $400 \mathrm{ft}$ downstream from the Interstate 8 bridge, 29 mi west of Casa Grande, $28 \mathrm{mi}$ east of Gila Bend, and $18 \mathrm{mi}$ west of Stanfield. The pin elevation (gage datum) is $4.64 \mathrm{ft}$. Elevation of gage is $1,625 \mathrm{ft}$ above NGVD of 1929, from topographic map. The FCDMC operates a stage pressure transducer, rain gage, and data transmitter in a shelter just downstream from the gage.

Drainage area-150 $\mathrm{mi}^{2}$.

Channel description-The channel is straight for about $1,000 \mathrm{ft}$ upstream and 2,000 ft downstream from the gage and is confined to a width of about $200 \mathrm{ft}$ by 10 - $\mathrm{ft}$ high, weakly cemented alluvial banks. The channel banks are covered with dense brush and trees, whereas the sand and gravel channel bed is, for the most part, clear of vegetation.

Most recent survey-October 28, 1998.

Cross-section locations-All endpoints are rebar. There is no cross-section 1.

Cross-section 2 is $190 \mathrm{ft}$ downstream from bridge, about $212 \mathrm{ft}$ upstream from the crest-stage gage.

Cross-section 3 is at the crest-stage gage.

Cross-section 4 is about $260 \mathrm{ft}$ downstream from the crest-stage gage.

Cross-section 5 is about $140 \mathrm{ft}$ downstream from crosssection 4 and about $400 \mathrm{ft}$ downstream from the creststage gage.

Cross-section 6 is about $250 \mathrm{ft}$ downstream from crosssection 5, not recovered in 1998. 


\section{Waterman Wash near Buckeye, Arizona}

Reach location-The channel-change monitoring reach extends $400 \mathrm{ft}$ upstream from a crest-stage gage to $410 \mathrm{ft}$ downstream. The crest-stage gage is at latitude $33^{\circ} 19^{\prime} 49^{\prime \prime N}$., longitude $112^{\circ} 30^{\prime} 33^{\prime \prime W}$., in SW1/4 NE1/4 sec. 24, T. 1 S., R. 3 W., Maricopa County, 2.4 mi upstream from mouth and $5.2 \mathrm{mi}$ southeast of Buckeye Post Office. The gage is on the left bank at edge of flat sand channel directly opposite an old gage site, which was on right bank about $500 \mathrm{ft}$ streamward (west) from several old buildings (pig farm) on right bank. Crosssection 2 spans an adjacent side channel entering Waterman Wash on the right side. This part of the section is referred to as cross-section $2 \mathrm{~A}$.

Drainage area-420 $\mathrm{mi}^{2}$.

Channel description-Waterman Wash is a wide, flat, ephemeral sand channel that flows through Rainbow Valley. The channel at the gaging station is mainly sand with some gravel and is incised into the valley alluvium. Large bushes are present in the channel, and the banks are lined with large trees and brush.

Most recent survey-December 20-21, 2000.

Cross-section locations-All endpoints are rebar.

Cross-section 1 is $400 \mathrm{ft}$ upstream from the crest-stage gage.

Cross-section 2 is $196 \mathrm{ft}$ upstream from the crest-stage gage.

Cross-section 2A is $196 \mathrm{ft}$ upstream from the crest-stage gage in side channel off of right bank.

Cross-section 3 is at the crest-stage gage.

Cross-section 4 is $205 \mathrm{ft}$ downstream from the creststage gage.

Cross-section 5 is $325 \mathrm{ft}$ downstream from the creststage gage.

Cross-section 6 is $410 \mathrm{ft}$ downstream from the creststage gage.

\section{Channel Change, 1997-2002}

The monitoring data for the 11 selected sites indicate that runoff and channel change are highly variable. These washes and streams are dry most of the time but are prone to flash flooding that causes significant scour and fill. Channel change is more likely to occur as discharge increases (Leopold and others, 1964); therefore, the selected sites were monitored for flows exceeding the 2-year recurrence interval (table 1). Current survey data for Jackrabbit Wash and the Hassayampa River near Arlington (Capesius and Lehman, 2002) support the idea that the most significant geomorphic change in predominately sand channels occurs in conjunction with peak flows above the 10-year recurrence interval.
The study channels fall into three categories: sand channels; bedrock, cobble, and gravel channels; and sand, gravel, and cobble channels. Sand channels typically are the most sensitive to scour and fill regimes (Leopold and others, 1964); however, they usually return to equilibrium except after very large flows. Sand channels in the study include Hassayampa River near Arlington, Hassayampa River near Morristown, Jackrabbit Wash, and Waterman Wash. Of these, only Jackrabbit Wash has experienced a peak of record, channel-changing flow. Agua Fria River, Cave Creek, Deadman Wash, New River, and Salt River are all bedrock, cobble, and gravel channels. Measured flows in these channels have all been below the 10-year recurrence interval during the study period. Sand, gravel, and cobble channels include Tiger Wash and Vekol Wash.

\section{Sand Channels}

The Hassayampa River near Arlington below the railroad bridge has a wide, braided, sandy channel bed in which the low-flow channel shifts laterally. The base line for the cross sections is Parker's 1991-92 study (Parker, 1995), and all section resurveys show both fill and scour during the study period. High flows in October 2000 entrenched the low-flow channel near the left bank from the head of the reach though cross-section 7. Sections 9 through 11, however, had increasing amounts of fill in the downstream direction.

The flat sandy channel at Hassayampa River near Morristown is confined by vertical bedrock canyon walls in most of the study reach. San Domingo Wash enters the Hassayampa between cross-section 1 and 2. The most recent resurvey shows a sand bar building along the left margin of the main channel. The bar's relief is greatest at cross-section 2 but the bar extends through cross-section 3.

Jackrabbit Wash near Tonopah is a sand channel with some gravel and cobble that is incised into banks of cohesive to semicohesive alluvium. All but three cross-section endpoints at Jackrabbit Wash were washed out in the record peak flow in October 2000. It has not been possible to correlate cross sections used in the indirect measurement survey (conducted after flow) to the original cross sections. The road upstream from the crest-stage gages, however, was buried in sand after the flow. In addition, channel change is indicated by photos taken before and after the record flow. Comparison between the indirect-measurement surveys done in 2000 and 2002 shows well-defined scour limited to the low-flow channels in cross-section 2 (fig. 7).

Waterman Wash near Buckeye is a flat sand channel about $120 \mathrm{ft}$ wide that has shallow banks of semicohesive alluvium. The peak-of-record flow, $9,400 \mathrm{ft}^{3} / \mathrm{s}$, occurred on August 8, 1997, but during the 5-year monitoring period there has been less than a foot of change throughout most of the reach (fig. 12). 


\section{Bedrock, Cobble, and Gravel Channels}

At Agua Fria River near Rock Springs, there has been little measurable channel change throughout the study reach over the 5-year monitoring period. Scour and fill is not large at cross-section 1, with the most change (about $1.5 \mathrm{ft}$ ) occurring in the low-flow channel close to the right bank (fig. 2). Crosssection 2 is in line with the gaging station and crosses the gaging-station pool. Elevation changes observed on the first flood terrace are most likely a function of the variation in the cross-section path between surveys. Measurements at crosssection 3 show apparent scour and fill but this also could be caused by the variation in the cross-section path. The rightbank endpoint at cross-section 3 was unrecoverable in January 2000 as was the right-bank endpoint at cross-section 4 .

Measured change at cross-section 4 is less than $0.5 \mathrm{ft}$.

The channel of Cave Creek below Cottonwood Creek is primarily cobble and gravel and is fairly straight throughout the study reach. The channel contracts starting from the road crossing just downstream from cross-section 6 all the way through cross-section 3, and all sections show apparent localized scour and fill (fig. 3). Cross-section 6 incurred fill in both the left and right low-flow channels, whereas crosssection 5 received the most scour, especially along the edges of the mid-channel gravel bar. This mid-channel gravel bar is present in all four cross sections, but by cross-section 3 the bar is thin and tapering downstream. The top of the bar also was scoured in cross-section 4 , but at this section there is only one well-defined low-flow channel along the right bank. At crosssection 3, the low-flow channel cuts near the left bank and stays to the left downstream past the gaging station. Scour in cross-section 3 occurs mainly in the low-flow channel.

Deadman Wash near New River had measurable scour in the upper two cross sections: cross-section 1, which is approximately $70 \mathrm{ft}$ upstream from the crest-stage gage, and cross-section 2, which is in line with the gaging station. The channel has expanded several feet to the right between crosssection 1 and cross-section 2, and at cross-section 1 there has been less than $0.5 \mathrm{ft}$ of measurable fill along the left bank (fig. 4). The cross sections downstream from the gaging station (cross-section 3, established in 1998; cross-section 5; and cross-section 6) have changed less than $0.5 \mathrm{ft}$. Cross-section 4 , along the downstream edge of a dirt road that crosses the wash, was measured in 1997 but was excluded in following surveys because the endpoints were unrecoverable and the surface was prone to artificial change due to road grading.
At New River at New River, all cross sections surveyed in 1997 were unrecoverable in 1999 and were reestablished at closest approximation to the original sections. Cross-section 4, along the abandoned cableway, is the closest to its original location. Cross-sections 3 and 4 exhibited little measurable change (fig. 8); the changes in section 5 could be a result of an offset from the original survey. Because there is no active stream gaging at this site, discharge values applied here are from streamflow-gaging station 09513780, New River near Rock Springs, which is about 10 mi upstream.

The channel at Salt River at Priest Drive is bedrock overlain by boulders, cobbles, and sandbars; is about $1,000 \mathrm{ft}$ wide; and is essentially straight for $1 \mathrm{mi}$ upstream and $1 \mathrm{mi}$ downstream from the gaging station. Both right and left banks are man-made levees. Monitoring at this site was discontinued after FCDMC graded the channelized riverbed during the winter of 1999-2000 in order to mitigate vegetation growth. It was concluded that most channel changes in this section of the Salt River would result directly or indirectly from alterations by humans (fig. 9).

\section{Sand, Gravel, and Cobble Channels}

Tiger Wash near Aguila is a flat sandy channel with large boulders near the right channel margin and bedrock on the left. Fill has been the dominant change in cross-sections 1-3 (fig. 10). Cross-section 1 has shown less than $1 \mathrm{ft}$ of change during the monitoring period, and larger changes on the left margin are due to changes in locations of the left endpoint. In cross-section 2, the original low-flow channel near the center of the main channel has continued to fill through time to the current mounded sandbar. Changes to cross-section 3 are similar to those at cross-section 2 but lesser in magnitude. Section 4 has had changes of less than $0.5 \mathrm{ft}$.

Vekol Wash near Stanfield is a flat sand and gravel channel confined by steep banks of semicohesive alluvium. The peak-of-record flow, $7,780 \mathrm{ft}^{3} / \mathrm{s}$, occurred at this site on July 25,1996 . The channel has been dry for most of the monitoring period, and there has been little measurable channel change. About $1 \mathrm{ft}$ of scour has occurred in the lowflow channel (cross-section 2), and about $1 \mathrm{ft}$ of fill has occurred at cross-sections 3 and 4 . At cross-section 5, there also was about $1 \mathrm{ft}$ of fill in the low-flow channel, but about $1 \mathrm{ft}$ of scour in the rest of the section (fig. 11). 


\section{Selected References}

Benson, M.A., and Dalrymple, Tate, 1967, General field and office procedures for indirect-discharge measurements: U.S. Geological Survey Techniques of Water-Resources Investigations, book 3, chap. A1, $30 \mathrm{p}$.

Burkham, D.E., 1970, Precipitation, streamflow, and major floods at selected sites in the Gila River drainage basin above Coolidge Dam, Arizona: U.S. Geological Survey Professional Paper 655-B, 33 p.

Capesius, J.P., and Lehman, T.W., 2002, Determination of channel change for selected streams, Maricopa County, Arizona: U.S. Geological Survey Water-Resources Investigations Report 01-4209, 63 p.

Dalrymple, Tate, and Benson, M.A., 1967, Measurement of peak discharge by the slope-area method: U.S. Geological Survey Techniques of Water-Resources Investigations, book 3, chap. A2, 12 p.

Foley, M.G., 1978, Scour and fill in steep, sand-bed ephemeral streams: Geological Society of America Bulletin, v. 89, no. 4 , p. $559-570$.
Graf, W.L., 1988, Fluvial process in dryland rivers: New York, Springer-Verlag, $346 \mathrm{p}$.

Jarrett, R.D., 1986, Evaluation of the slope-area method of computing peak discharge, in Subitzky, Seymour, ed., Selected Papers in the Hydrologic Sciences 1986: U.S. Geological Survey Water-Supply Paper 2310, p. 13-24.

Kirby, W.H., 1981, Annual flood frequency analysis using U.S. Water Resources Council guidelines (program J407): U.S. Geological Survey Open-File Report 79-1336-I, WATSTORE User's Guide, v. 4, chap. I, sec. C, 56 p.

Leopold, L.B., Wolman, M.G., and Miller, J.P., 1964, Fluvial processes in geomorphology: San Francisco, California, W.H. Freeman and Company, $522 \mathrm{p}$.

Parker, J.T.C., 1995, Channel change and sediment transport in two desert streams in central Arizona, 1991-92: U.S. Geological Survey Water-Resources Investigations Report 95-4059, 42 p.

Pope, G.L., Rigas, P.D., and Smith C.F., 1998, Statistical summaries of streamflow data and characteristics of drainage basins for selected streamflow-gaging stations in Arizona through water year 1996: U.S Geological Survey Water-Resources Investigations Report 98-4225, 907 p. 


\section{Cross-Section Data}

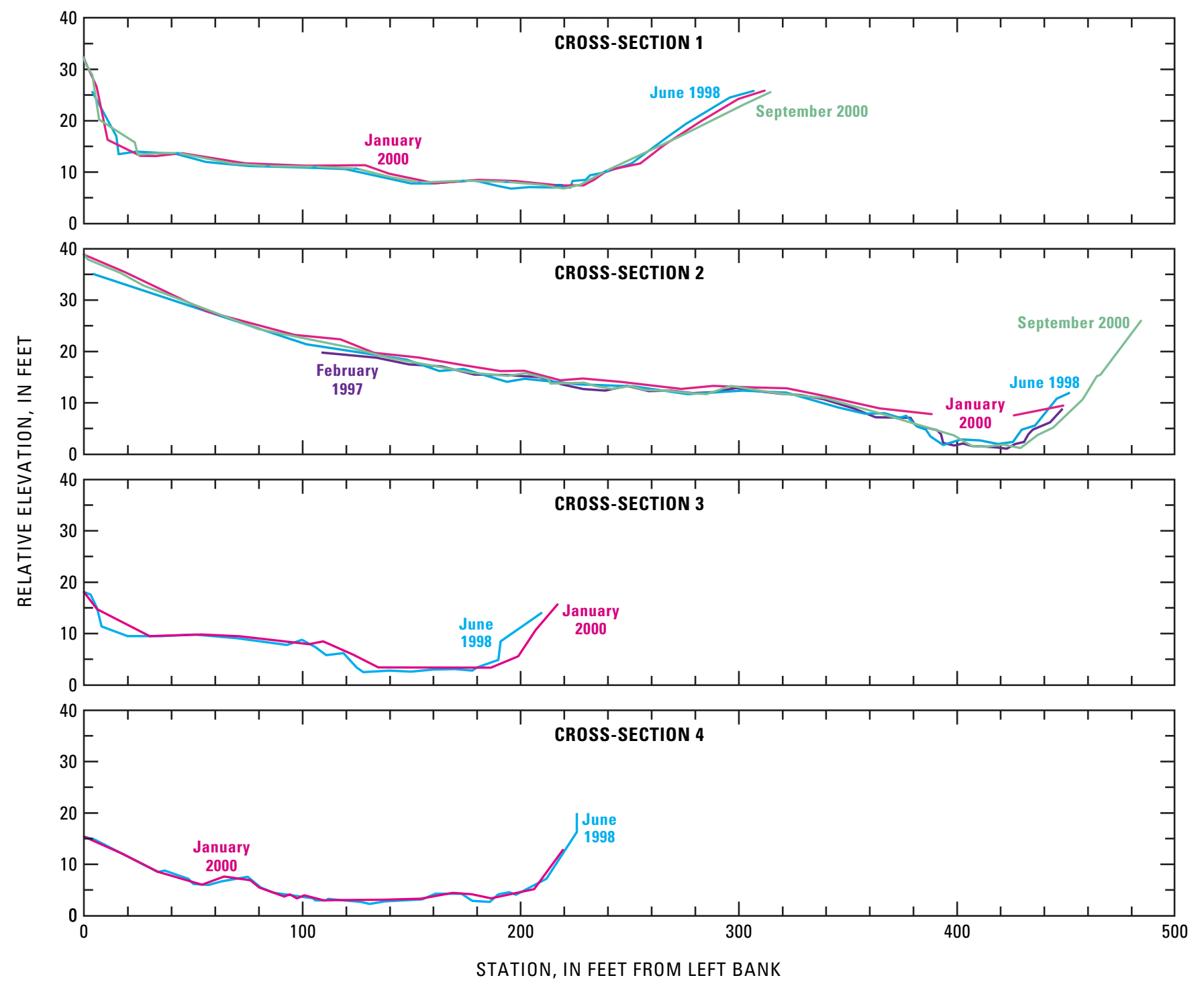

Figure 2. Channel-change cross sections from surveys at Agua Fria River near Rock Springs, Arizona, 1997-2000. 
Table 2. Data from surveys at Agua Fria River near Rock Springs, Arizona, 1997-2000

[Values in feet above local datum (see explanation in text). Station locations are distances from left bank]

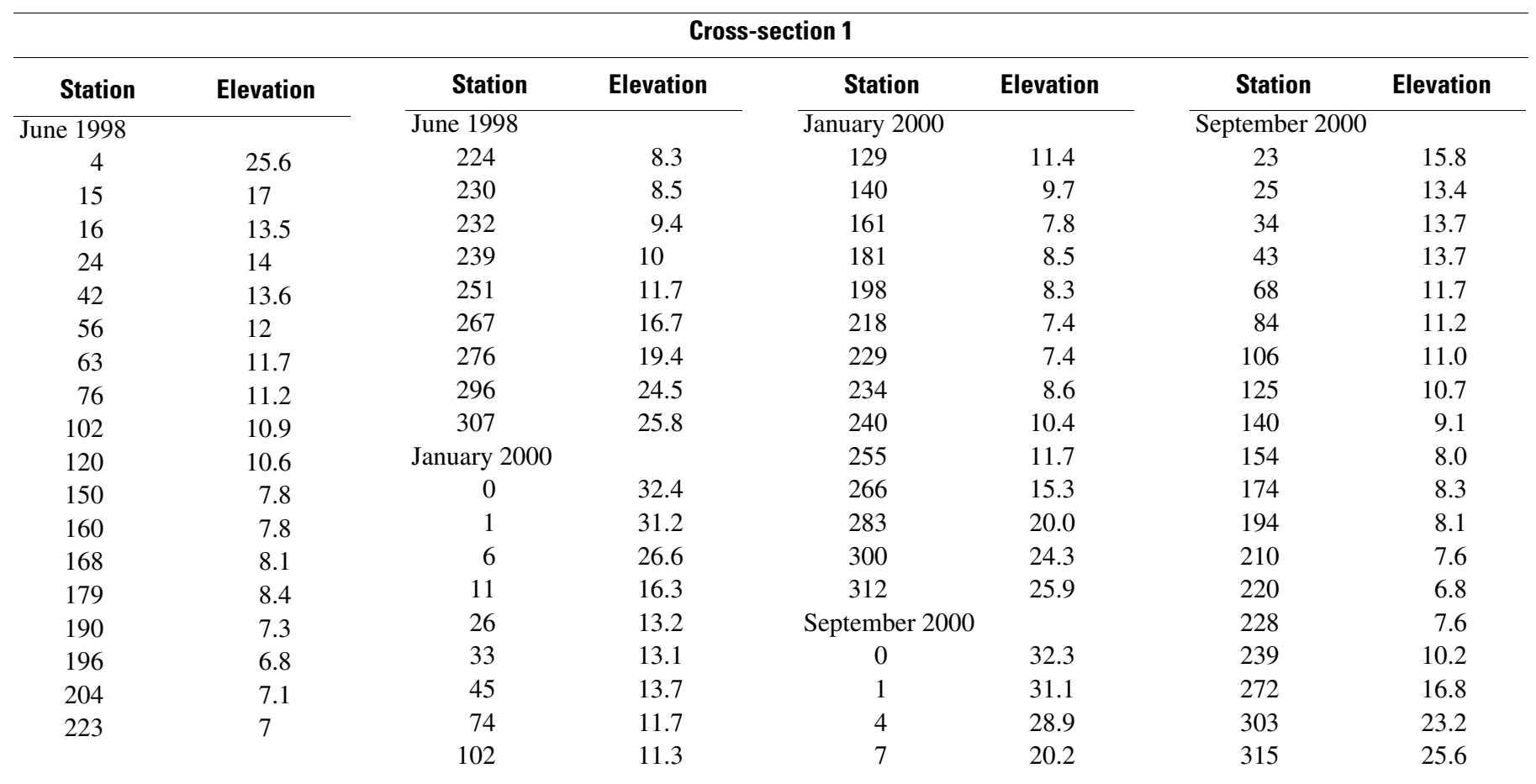




\section{Data from Channel-Change Monitoring at Selected Sites in Maricopa County, Arizona, 1997-2002}

Table 2. Data from surveys at Agua Fria River near Rock Springs, Arizona, 1997-2000—Continued

[Values in feet above local datum (see explanation in text). Station locations are distances from left bank]

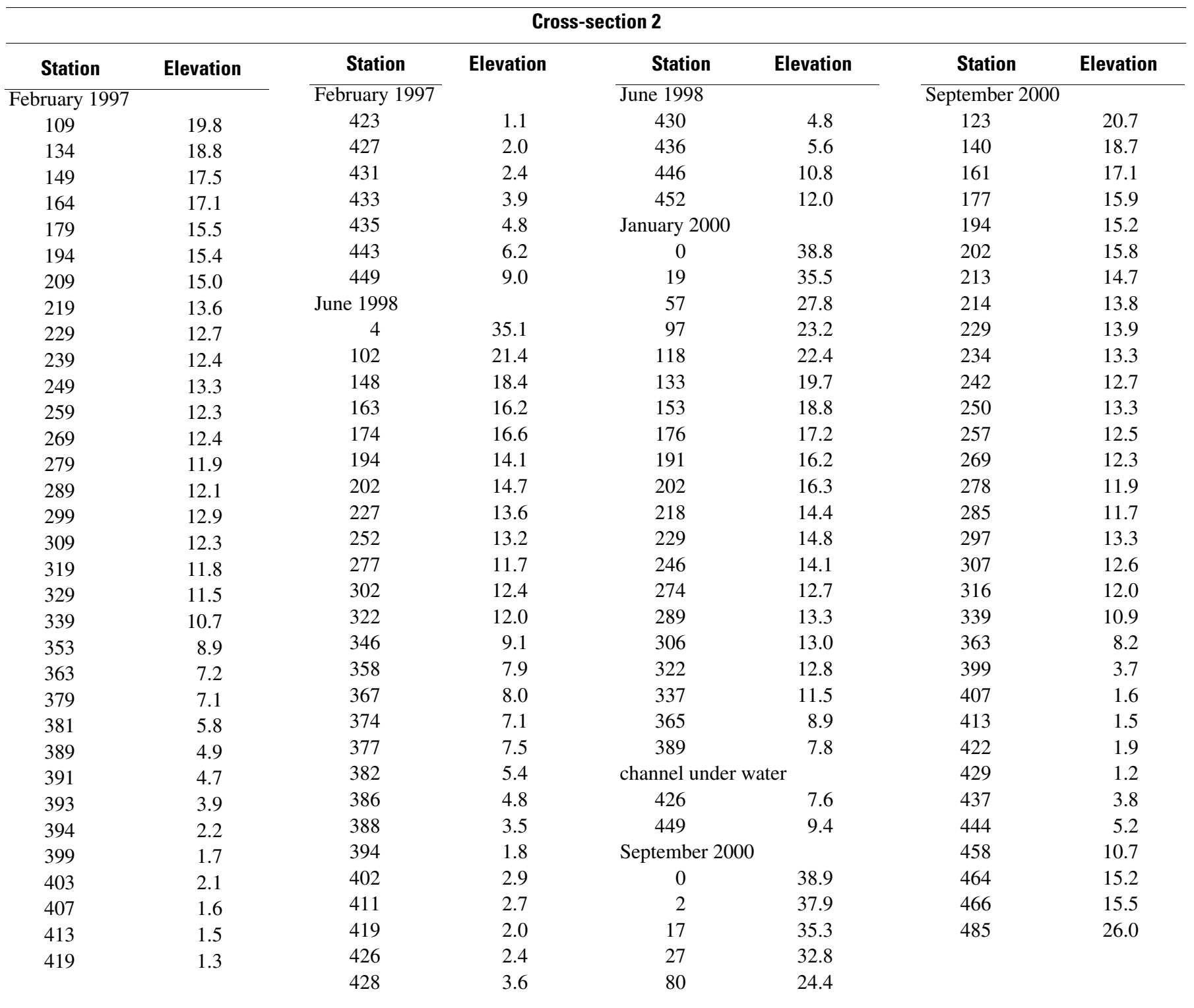


Table 2. Data from surveys at Agua Fria River near Rock Springs, Arizona, 1997-2000_Continued

[Values in feet above local datum (see explanation in text). Station locations are distances from left bank]

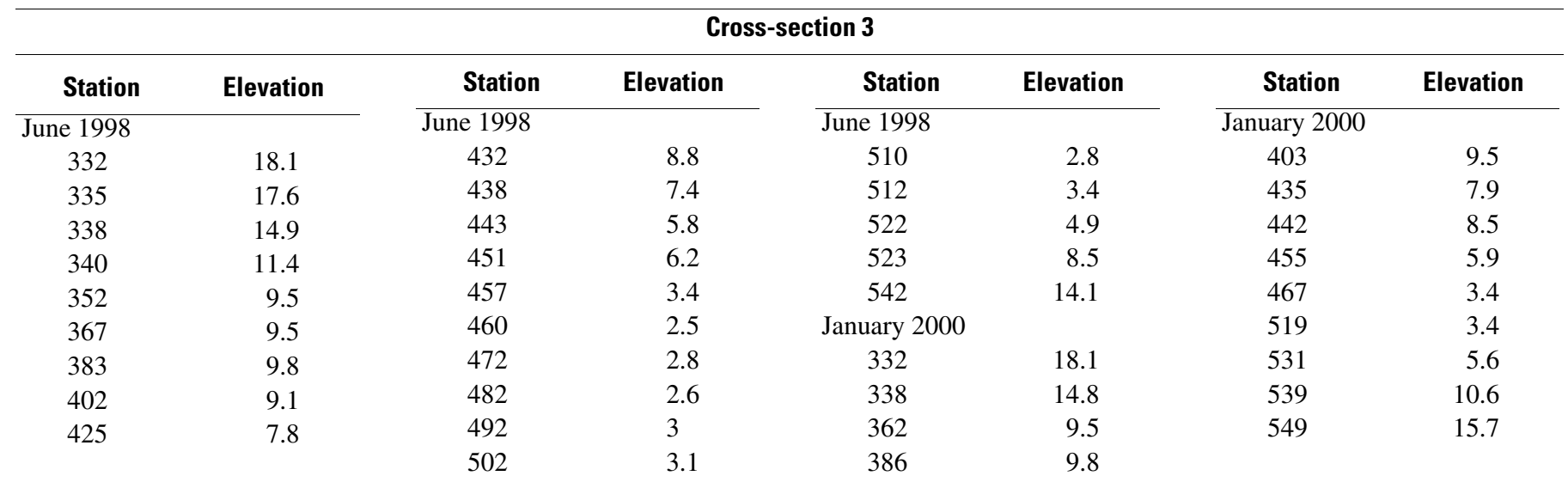

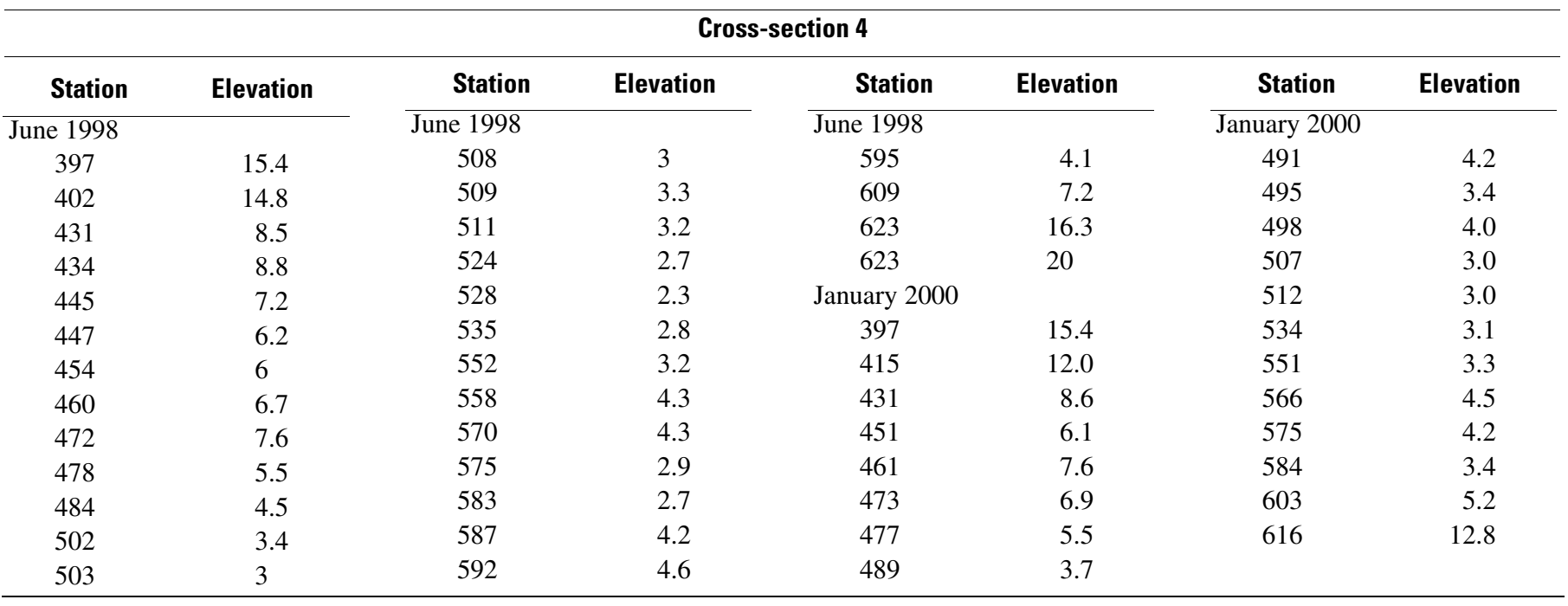




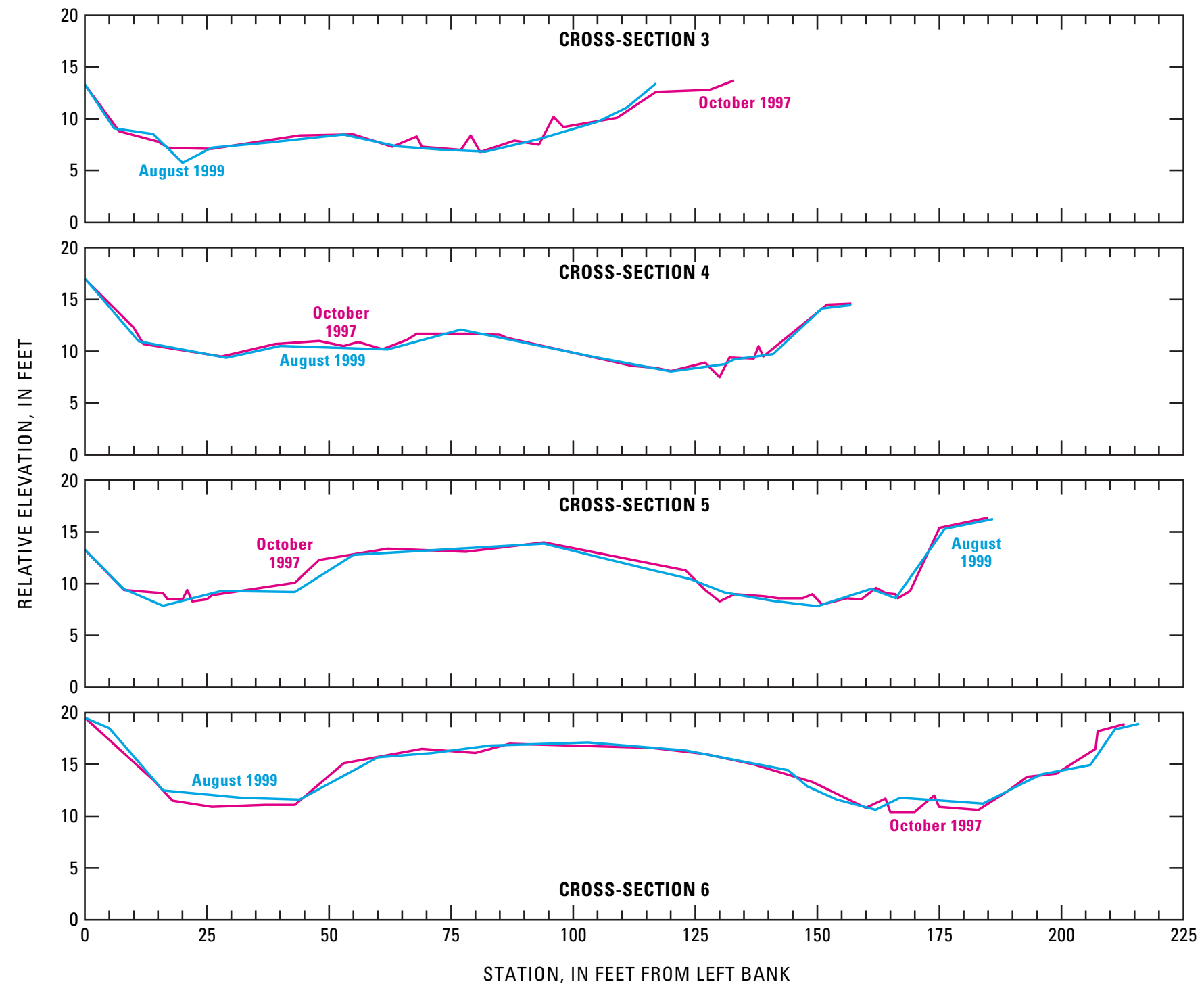

Figure 3. Channel-change cross sections from surveys at Cave Creek below Cottonwood Creek, near Cave Creek, Arizona, $1997-99$.

Table 3. Data from surveys at Cave Creek below Cottonwood Creek, near Cave Creek, Arizona, 1997-99

[Values in feet above local datum (see explanation in text). Station locations are distances from left bank]

\begin{tabular}{|c|c|c|c|c|c|c|c|}
\hline \multicolumn{8}{|c|}{ Cross-section 3} \\
\hline Station & Elevation & Station & Elevation & Station & Elevation & Station & Elevation \\
\hline October 1997 & & October 1997 & & October 1997 & & August 1999 & \\
\hline 0 & 13.3 & 69 & 7.3 & 117 & 12.6 & 38 & 7.7 \\
\hline 7 & 8.8 & 77 & 7 & 128 & 12.8 & 53 & 8.5 \\
\hline 15 & 7.8 & 79 & 8.4 & 133 & 13.7 & 64 & 7.3 \\
\hline 17 & 7.2 & 81 & 6.8 & August 1999 & & 73 & 7.0 \\
\hline 26 & 7.1 & 88 & 7.9 & 0 & 13.3 & 82 & 6.8 \\
\hline 44 & 8.4 & 93 & 7.5 & 6 & 9.1 & 93 & 8.0 \\
\hline 55 & 8.5 & 96 & 10.2 & 14 & 8.5 & 105 & 9.7 \\
\hline 63 & 7.3 & 98 & 9.2 & 20 & 5.8 & 111 & 11.1 \\
\hline 68 & 8.3 & 109 & 10.1 & 26 & 7.2 & 117 & 13.4 \\
\hline
\end{tabular}


Table 3. Data from surveys at Cave Creek below Cottonwood Creek, near Cave Creek, Arizona, 1997-99_Continued

[Values in feet above local datum (see explanation in text). Station locations are distances from left bank]

\begin{tabular}{|c|c|c|c|c|c|c|c|}
\hline \multicolumn{8}{|c|}{ Cross-section 4} \\
\hline Station & Elevation & Station & Elevation & Station & Elevation & Station & Elevation \\
\hline October 1997 & & October 1997 & & October 1997 & & August 1999 & \\
\hline 0 & 17.0 & 68 & 11.7 & 137 & 9.3 & 62 & 10.2 \\
\hline 10 & 12.3 & 78 & 11.7 & 138 & 10.5 & 77 & 12.1 \\
\hline 12 & 10.7 & 85 & 11.6 & 139 & 9.5 & 104 & 9.5 \\
\hline 28 & 9.5 & 86.5 & 11.3 & 152 & 14.5 & 120 & 8.1 \\
\hline 39 & 10.7 & 112 & 8.6 & 157 & 14.6 & 131 & 8.8 \\
\hline 48 & 11.0 & 117 & 8.4 & August 1999 & & 133 & 9.2 \\
\hline 53 & 10.5 & 120 & 8.1 & 0 & 17.0 & 141 & 9.7 \\
\hline 56 & 10.9 & 127 & 8.9 & 11 & 11.0 & 151 & 14.1 \\
\hline 61 & 10.2 & 130 & 7.5 & 29 & 9.4 & 157 & 14.5 \\
\hline 66 & 11.1 & 132 & 9.4 & 40 & 10.5 & & \\
\hline
\end{tabular}

\begin{tabular}{|c|c|c|c|c|c|c|c|}
\hline \multicolumn{8}{|c|}{ Cross-section 5} \\
\hline Station & Elevation & Station & Elevation & Station & Elevation & Station & Elevation \\
\hline October 1997 & & October 1997 & & October 1997 & & August 1999 & \\
\hline 0 & 13.3 & 94 & 14.0 & 162 & 9.6 & 55 & 12.8 \\
\hline 8 & 9.4 & 123 & 11.3 & 164 & 9.1 & 94 & 13.9 \\
\hline 16 & 9.1 & 127 & 9.4 & 166 & 9 & 116 & 11.4 \\
\hline 17 & 8.5 & 130 & 8.3 & 166.5 & 8.6 & 124 & 10.5 \\
\hline 20 & 8.5 & 133 & 9.0 & 169 & 9.3 & 131 & 9.2 \\
\hline 21 & 9.4 & 139 & 8.8 & 175 & 15.4 & 141 & 8.3 \\
\hline 22 & 8.3 & 142 & 8.6 & 185 & 16.4 & 150 & 7.8 \\
\hline 25 & 8.5 & 145 & 8.6 & August 1999 & & 161 & 9.5 \\
\hline 26 & 8.9 & 147 & 8.6 & 0 & 13.3 & 166 & 8.6 \\
\hline 43 & 10.1 & 149 & 9.0 & 8 & 9.5 & 176 & 15.3 \\
\hline 48 & 12.3 & 151 & 8.0 & 16 & 7.9 & 186 & 16.3 \\
\hline 62 & 13.4 & 156 & 8.6 & 28 & 9.3 & & \\
\hline 78 & 13.1 & 159 & 8.5 & 43 & 9.2 & & \\
\hline
\end{tabular}

\begin{tabular}{|c|c|c|c|c|c|c|c|}
\hline \multicolumn{8}{|c|}{ Cross-section 6} \\
\hline Station & Elevation & Station & Elevation & Station & Elevation & Station & Elevation \\
\hline October 1997 & & October 1997 & & October 1997 & & August 1999 & \\
\hline 0 & 19.5 & 137 & 15 & 207.5 & 18.2 & 144 & 14.4 \\
\hline 14 & 13.5 & 149 & 13.3 & 213 & 18.9 & 148 & 12.9 \\
\hline 18 & 11.5 & 160 & 10.8 & August 1999 & & 154 & 11.6 \\
\hline 26 & 10.9 & 164 & 11.7 & 0 & 19.5 & 162 & 10.6 \\
\hline 37 & 11.1 & 165 & 10.4 & 5 & 18.5 & 167 & 11.8 \\
\hline 43 & 11.1 & 170 & 10.4 & 16 & 12.5 & 184 & 11.2 \\
\hline 53 & 15.1 & 174 & 12 & 32 & 11.8 & 192 & 13.1 \\
\hline 69 & 16.5 & 175 & 10.9 & 44 & 11.6 & 196 & 14.0 \\
\hline 80 & 16.1 & 183 & 10.6 & 60 & 15.7 & 206 & 14.9 \\
\hline 87 & 17 & 189 & 12.4 & 71 & 16.1 & 211 & 18.4 \\
\hline 116 & 16.6 & 193 & 13.8 & 83 & 16.8 & 216 & 18.9 \\
\hline \multirow[t]{2}{*}{127} & 16 & 199 & 14.1 & 103 & 17.1 & & \\
\hline & & 207 & 16.5 & 123 & 16.4 & & \\
\hline
\end{tabular}




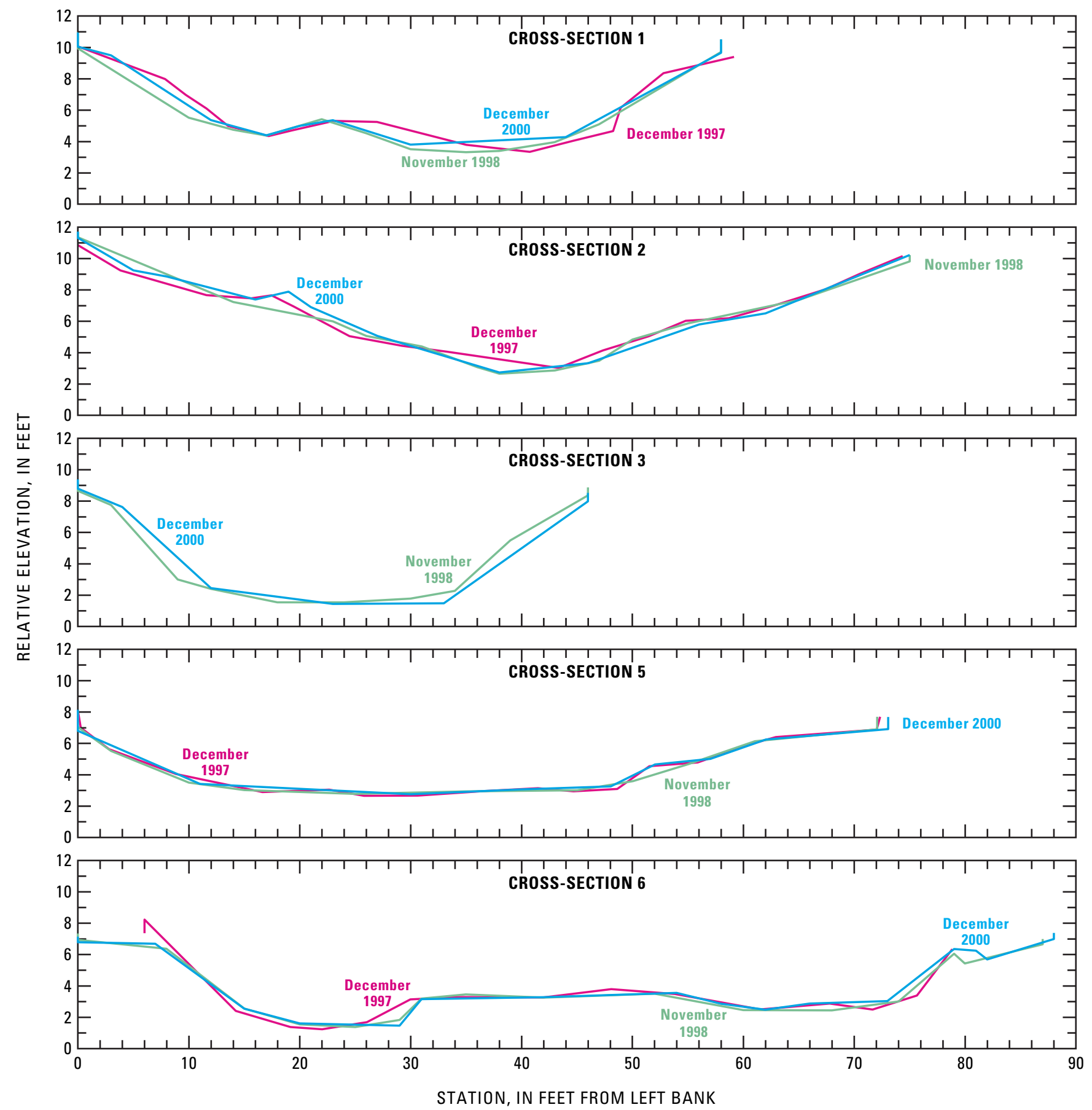

Figure 4. Channel-change cross sections from surveys at Deadman Wash near New River, Arizona, 1997-2000. 
Table 4. Data from surveys at Deadman Wash near New River, Arizona, 1997-2000

[Values in feet above local datum (see explanation in text). Station locations are distances from left bank. Cross-section 3 established in 1998]

\begin{tabular}{|c|c|c|c|c|c|c|c|}
\hline \multicolumn{8}{|c|}{ Cross-section 1} \\
\hline Station & Elevation & Station & Elevation & Station & Elevation & Station & Elevation \\
\hline December 1997 & & December 1997 & & November 1998 & & December 2000 & \\
\hline 0 & 10.1 & 41 & 3.3 & 17 & 4.4 & 0 & 10.9 \\
\hline 8 & 8.0 & 45 & 4.0 & 22 & 5.4 & 0 & 10.0 \\
\hline 10 & 7.0 & 48 & 4.7 & 26 & 4.5 & 3 & 9.5 \\
\hline 12 & 6.1 & 49 & 6.1 & 30 & 3.5 & 12 & 5.4 \\
\hline 14 & 5.0 & 53 & 8.3 & 35 & 3.3 & 17 & 4.4 \\
\hline 17 & 4.3 & 59 & 9.4 & 38 & 3.4 & 20 & 5.0 \\
\hline 19 & 4.7 & November 1998 & & 43 & 4.0 & 23 & 5.3 \\
\hline 23 & 5.3 & 0 & 11.0 & 47 & 5.1 & 30 & 3.8 \\
\hline 27 & 5.2 & 0 & 9.9 & 58 & 9.7 & 44 & 4.3 \\
\hline 31 & 4.5 & 10 & 5.5 & 58 & 10.5 & 58 & 9.6 \\
\hline 35 & 3.8 & 14 & 4.7 & & & 58 & 10.5 \\
\hline
\end{tabular}

\begin{tabular}{|c|c|c|c|c|c|c|c|}
\hline \multicolumn{8}{|c|}{ Cross-section 2} \\
\hline Station & Elevation & Station & Elevation & Station & Elevation & Station & Elevation \\
\hline December 1997 & & December 1997 & & November 1998 & & December 2000 & \\
\hline 0 & 10.8 & 55 & 6.0 & 36 & 3.1 & 5 & 9.2 \\
\hline 4 & 9.2 & 59 & 6.2 & 38 & 2.7 & 8 & 8.9 \\
\hline 12 & 7.7 & 63 & 7.0 & 39 & 2.7 & 16 & 7.4 \\
\hline 16 & 7.5 & 67 & 8.0 & 43 & 2.9 & 19 & 7.9 \\
\hline 17 & 7.6 & 70 & 9.0 & 47 & 3.5 & 21 & 6.9 \\
\hline 19 & 6.9 & 74 & 10.1 & 50 & 4.8 & 27 & 5.1 \\
\hline 24 & 5.0 & November 1998 & & 55 & 5.9 & 38 & 2.7 \\
\hline 29 & 4.4 & 0 & 11.7 & 65 & 7.4 & 46 & 3.3 \\
\hline 33 & 4.1 & 0 & 11.4 & 75 & 9.8 & 56 & 5.8 \\
\hline 43 & 3.0 & 14 & 7.2 & 75 & 10.2 & 62 & 6.5 \\
\hline 47 & 4.1 & 23 & 6.0 & December 2000 & & 75 & 10.2 \\
\hline \multirow[t]{2}{*}{51} & 5.0 & 26 & 5.1 & 0 & 11.7 & & \\
\hline & & 31 & 4.4 & 0 & 11.3 & & \\
\hline \multicolumn{8}{|c|}{ Cross-section 3} \\
\hline Station & Elevation & Station & Elevation & Station & Elevation & Station & Elevation \\
\hline November 1998 & & November 1998 & & December 2000 & & December 2000 & \\
\hline 0 & 9.2 & 24 & 1.5 & 0 & 9.4 & 46 & 8.0 \\
\hline 0 & 8.7 & 30 & 1.8 & 0 & 8.8 & 46 & 8.5 \\
\hline 3 & 7.8 & 34 & 2.3 & 4 & 7.6 & & \\
\hline 9 & 3.0 & 39 & 5.5 & 12 & 2.5 & & \\
\hline 12 & 2.4 & 46 & 8.4 & 23 & 1.4 & & \\
\hline 18 & 1.5 & 46 & 8.9 & 33 & 1.5 & & \\
\hline
\end{tabular}




\section{Data from Channel-Change Monitoring at Selected Sites in Maricopa County, Arizona, 1997-2002}

Table 4. Data from surveys at Deadman Wash near New River, Arizona, 1997-2000_Continued

[Values in feet above local datum (see explanation in text). Station locations are distances from left bank. Cross-section 3 established in 1998]

\begin{tabular}{|c|c|c|c|c|c|c|c|}
\hline \multicolumn{8}{|c|}{ Cross-section 5} \\
\hline Station & Elevation & Station & Elevation & Station & Elevation & Station & Elevation \\
\hline December 1997 & & December 1997 & & November 1998 & & December 2000 & \\
\hline 0 & 8.1 & 49 & 3.1 & 10 & 3.5 & 0 & 8.1 \\
\hline 0 & 7.0 & 51 & 4.5 & 15 & 3.0 & 0 & 6.8 \\
\hline 3 & 5.6 & 56 & 4.8 & 25 & 2.8 & 11 & 3.4 \\
\hline 9 & 4.0 & 60 & 5.9 & 35 & 2.9 & 20 & 3.1 \\
\hline 17 & 2.9 & 63 & 6.4 & 45 & 3.0 & 30 & 2.8 \\
\hline 23 & 3.0 & 72 & 6.9 & 50 & 3.6 & 40 & 3.1 \\
\hline 26 & 2.7 & 72 & 7.7 & 55 & 4.7 & 48 & 3.3 \\
\hline 31 & 2.7 & November 1998 & & 61 & 6.1 & 52 & 4.7 \\
\hline 37 & 3.0 & 0 & 8.1 & 72 & 6.9 & 57 & 5.0 \\
\hline 41 & 3.1 & 0 & 7.0 & 72 & 7.7 & 62 & 6.3 \\
\hline \multirow[t]{2}{*}{45} & 2.9 & 3 & 5.5 & & & 73 & 6.9 \\
\hline & & & & & & 73 & 7.7 \\
\hline \multicolumn{8}{|c|}{ Cross-section 6} \\
\hline Station & Elevation & Station & Elevation & Station & Elevation & Station & Elevation \\
\hline \multicolumn{2}{|l|}{ December 1997} & \multicolumn{2}{|l|}{ December 1997} & \multicolumn{2}{|l|}{ November 1998} & December 2000 & \\
\hline 6 & 8.2 & 72 & 2.5 & 52 & 3.5 & 29 & 1.5 \\
\hline 6 & 7.4 & 76 & 3.4 & 60 & 2.5 & 31 & 3.2 \\
\hline 14 & 2.4 & 79 & 6.3 & 68 & 2.4 & 42 & 3.3 \\
\hline 19 & 1.4 & November 1998 & & 74 & 3.0 & 54 & 3.6 \\
\hline 22 & 1.2 & 0 & 7.4 & 79 & 6.1 & 58 & 2.9 \\
\hline 26 & 1.7 & 0 & 6.9 & 80 & 5.4 & 62 & 2.5 \\
\hline 30 & 3.1 & 8 & 6.4 & 87 & 6.7 & 66 & 2.9 \\
\hline 34 & 3.3 & 15 & 2.6 & 87 & 7.0 & 73 & 3.0 \\
\hline 42 & 3.3 & 20 & 1.6 & December 2000 & & 79 & 6.4 \\
\hline 48 & 3.8 & 25 & 1.4 & 0 & 7.1 & 81 & 6.3 \\
\hline 54 & 3.5 & 29 & 1.8 & 0 & 6.8 & 82 & 5.7 \\
\hline 62 & 2.5 & 31 & 3.2 & 7 & 6.7 & 88 & 7.0 \\
\hline \multirow[t]{2}{*}{68} & 2.9 & 35 & 3.5 & 15 & 2.5 & 88 & 7.4 \\
\hline & & 42 & 3.3 & 20 & 1.6 & & \\
\hline
\end{tabular}



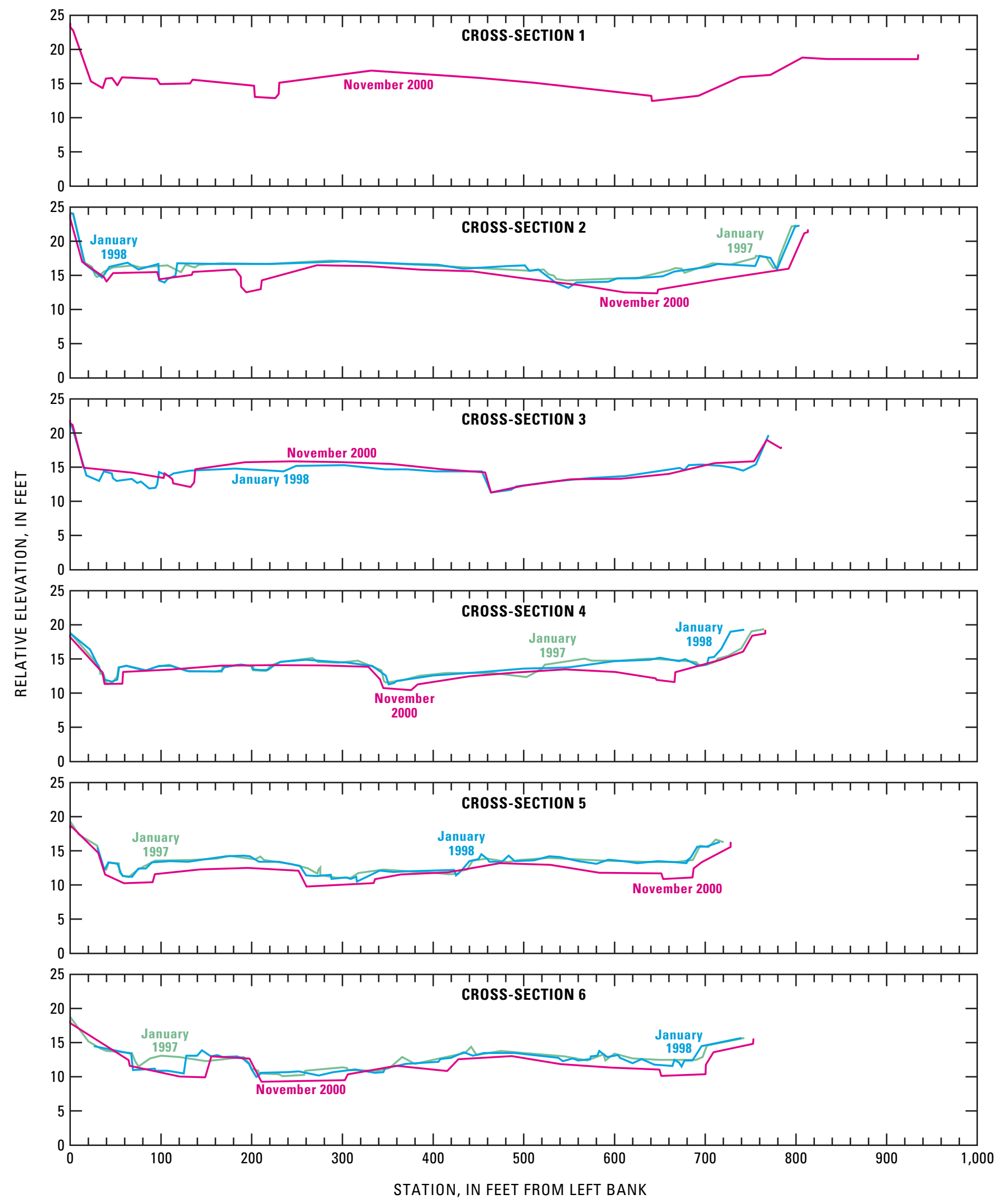

Figure 5. Channel-change cross sections from surveys at Hassayampa River near Arlington, Arizona, 1997-2000. 


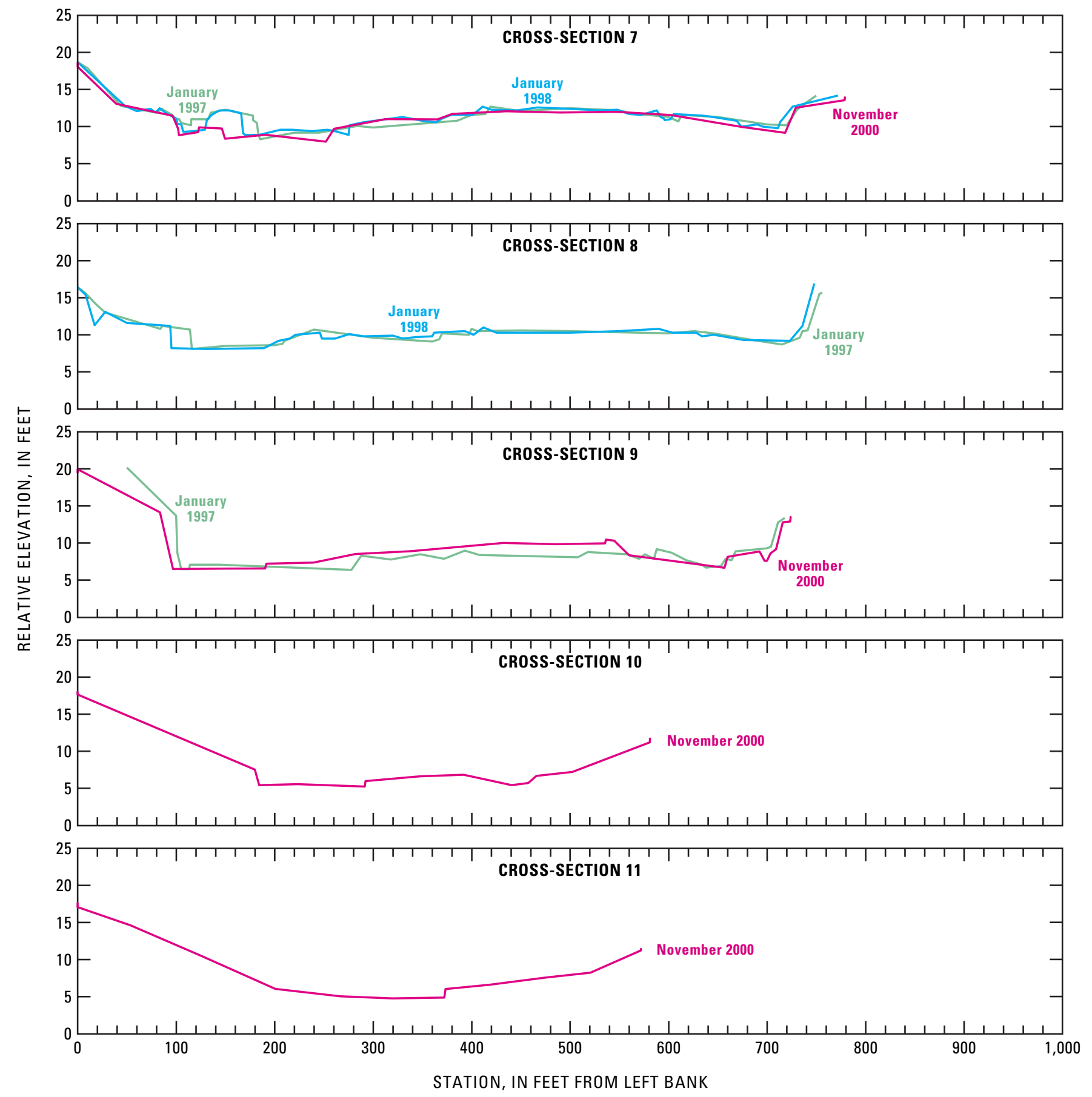

Figure 5.-Continued. 
Table 5. Data from surveys at Hassayampa River near Arlington, Arizona, 1997-2000

[Values in feet above local datum (see explanation in text). Station locations are distances from left bank. Endpoints for cross-section 8 unrecoverable in 2000]

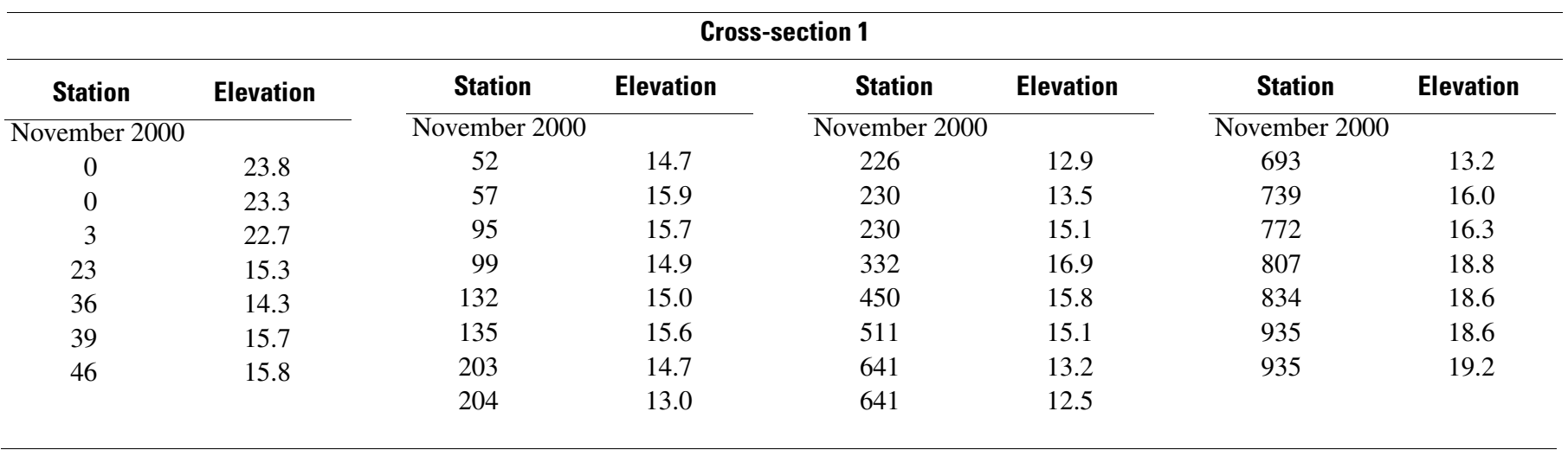

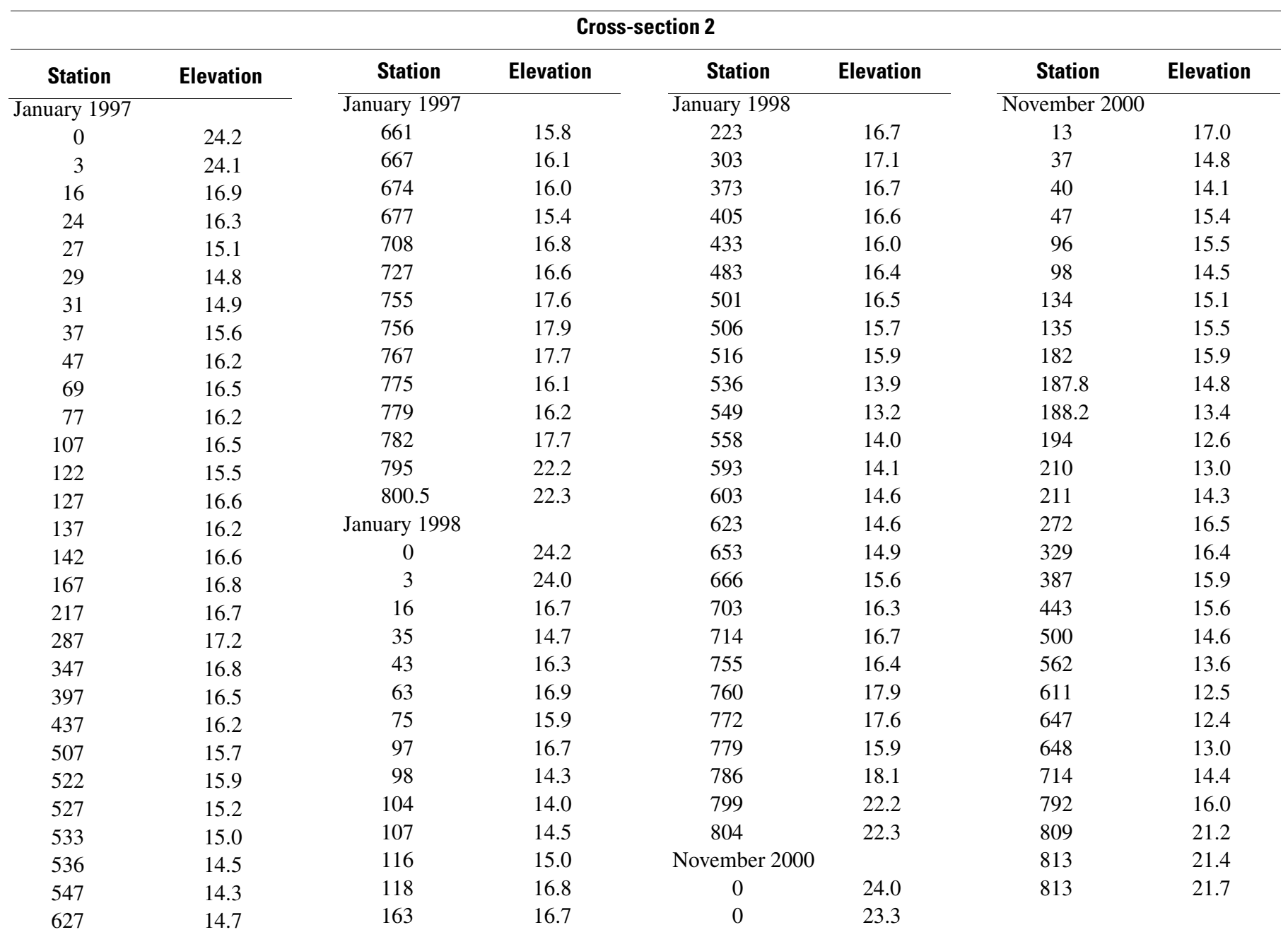




\section{Data from Channel-Change Monitoring at Selected Sites in Maricopa County, Arizona, 1997-2002}

Table 5. Data from surveys at Hassayampa River near Arlington, Arizona, 1997-2000—Continued

[Values in feet above local datum (see explanation in text). Station locations are distances from left bank. Endpoints for cross-section 8 unrecoverable in 2000]

\begin{tabular}{|c|c|c|c|c|c|c|c|}
\hline \multicolumn{8}{|c|}{ Cross-section 3} \\
\hline Station & Elevation & Station & Elevation & Station & Elevation & Station & Elevation \\
\hline January 1998 & & January 1998 & & January 1998 & & November 2000 & \\
\hline 0 & 21.5 & 182 & 14.8 & 696 & 15.4 & 138 & 14.7 \\
\hline 0 & 21.1 & 222 & 14.5 & 718 & 15.2 & 193 & 15.7 \\
\hline 2 & 21.0 & 235 & 14.4 & 732 & 14.9 & 245 & 15.9 \\
\hline 18 & 13.8 & 249 & 15.2 & 742 & 14.5 & 297 & 15.8 \\
\hline 32 & 13.0 & 302 & 15.3 & 756 & 15.4 & 353 & 15.5 \\
\hline 37 & 14.4 & 347 & 14.7 & 770 & 19.7 & 408 & 14.7 \\
\hline 46 & 14.1 & 372 & 14.7 & November 2000 & & 457 & 14.3 \\
\hline 47 & 13.4 & 402 & 14.4 & 0 & 21.8 & 464 & 11.3 \\
\hline 51 & 13.0 & 454 & 14.4 & 0 & 21.5 & 499 & 12.3 \\
\hline 68 & 13.3 & 464 & 11.3 & 3 & 21.2 & 552 & 13.2 \\
\hline 74 & 12.7 & 486 & 11.7 & 15 & 14.9 & 607 & 13.3 \\
\hline 78 & 12.9 & 492 & 12.2 & 70 & 14.2 & 660 & 14.0 \\
\hline 87 & 11.9 & 532 & 12.9 & 103 & 13.4 & 711 & 15.6 \\
\hline 94 & 12.0 & 572 & 13.4 & 104 & 14.1 & 754 & 15.9 \\
\hline 96 & 12.5 & 612 & 13.7 & 113 & 13.3 & 768 & 19.0 \\
\hline 98 & 14.3 & 672 & 14.9 & 114 & 12.6 & 784 & 17.8 \\
\hline 109 & 13.7 & 677 & 14.6 & 133 & 12.1 & 784 & 17.9 \\
\hline 114 & 14.1 & 682 & 15.3 & 137 & 12.8 & & \\
\hline 132 & 14.5 & & & & & & \\
\hline
\end{tabular}


Table 5. Data from surveys at Hassayampa River near Arlington, Arizona, 1997-2000—Continued

[Values in feet above local datum (see explanation in text). Station locations are distances from left bank. Endpoints for cross-section 8 unrecoverable in 2000]

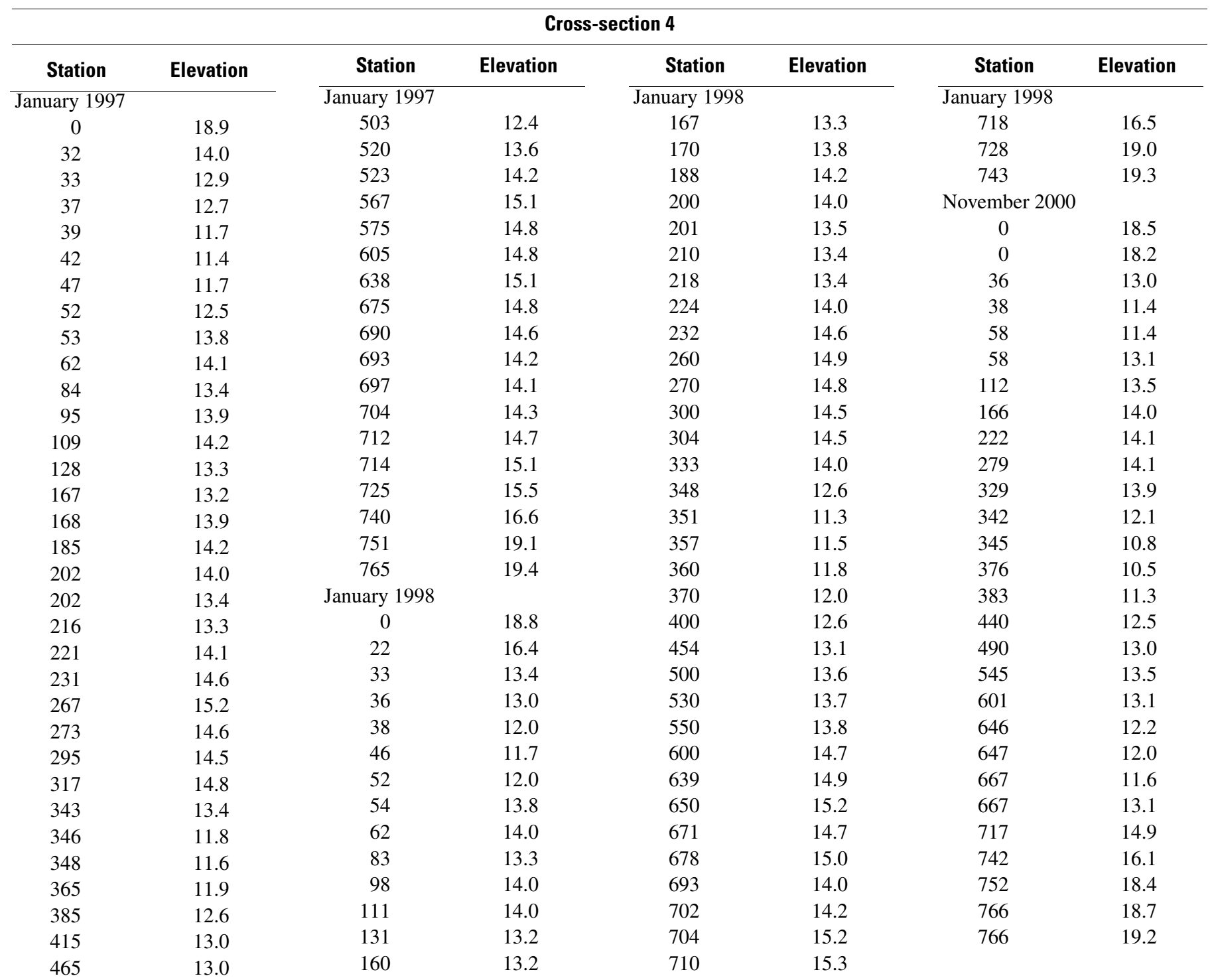




\section{Data from Channel-Change Monitoring at Selected Sites in Maricopa County, Arizona, 1997-2002}

Table 5. Data from surveys at Hassayampa River near Arlington, Arizona, 1997-2000—Continued

[Values in feet above local datum (see explanation in text). Station locations are distances from left bank. Endpoints for cross-section 8 unrecoverable in 2000]

\begin{tabular}{|c|c|c|c|c|c|c|c|}
\hline \multicolumn{8}{|c|}{ Cross-section 5} \\
\hline Station & Elevation & Station & Elevation & Station & Elevation & Station & Elevation \\
\hline January 1997 & & January 1997 & & 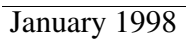 & & January 1998 & \\
\hline 0 & 19.3 & 443.5 & 13.6 & 260 & 11.4 & 679 & 13.2 \\
\hline 9.5 & 17.4 & 459.5 & 13.9 & 272 & 11.3 & 681 & 13.6 \\
\hline 29.5 & 15.8 & 482.5 & 13.4 & 287 & 11.5 & 680 & 13.6 \\
\hline 36.5 & 12.4 & 495.5 & 13.7 & 288 & 10.9 & 684 & 14.0 \\
\hline 39.5 & 12.3 & 527.5 & 14.0 & 304 & 11.1 & 691 & 15.6 \\
\hline 42.5 & 13.3 & 587.5 & 13.6 & 309 & 10.9 & 701 & 15.6 \\
\hline 53.5 & 13.2 & 641.5 & 13.4 & 315 & 11.2 & 716 & 16.3 \\
\hline 54.5 & 11.9 & 667.5 & 13.4 & 316 & 10.5 & November 2000 & \\
\hline 57.5 & 11.4 & 686.5 & 13.7 & 341 & 12.1 & 0 & 18.3 \\
\hline 64.5 & 11.2 & 694.5 & 15.8 & 356 & 11.9 & 0 & 18.7 \\
\hline 74.5 & 12.3 & 703.5 & 15.6 & 370 & 12.0 & 31 & 14.7 \\
\hline 93.5 & 13.6 & 711.5 & 16.7 & 400 & 12.1 & 39 & 11.5 \\
\hline 133.5 & 13.7 & 720.5 & 16.3 & 423 & 12.2 & 59 & 10.3 \\
\hline 161.5 & 13.9 & January 1998 & & 425 & 11.4 & 91 & 10.4 \\
\hline 175.5 & 14.3 & 30 & 15.5 & 428 & 11.7 & 93 & 11.6 \\
\hline 203.5 & 13.8 & 37 & 12.4 & 431 & 12.1 & 143 & 12.3 \\
\hline 209.5 & 14.2 & 38 & 12.3 & 440 & 13.5 & 196 & 12.5 \\
\hline 213.5 & 13.7 & 42 & 13.3 & 450 & 13.8 & 251 & 12.1 \\
\hline 243.5 & 13.1 & 52 & 13.1 & 453 & 14.5 & 261 & 9.8 \\
\hline 261.5 & 12.5 & 56 & 11.7 & 460 & 13.8 & 334 & 10.3 \\
\hline 272.5 & 11.7 & 58 & 11.3 & 462 & 13.4 & 336 & 10.8 \\
\hline 273.5 & 12.3 & 68 & 11.2 & 476 & 13.4 & 365 & 11.6 \\
\hline 275.5 & 12.6 & 75 & 12.4 & 483 & 14.3 & 416 & 11.8 \\
\hline 275.5 & 11.5 & 83 & 12.4 & 490 & 13.5 & 474 & 13.2 \\
\hline 293.5 & 11.1 & 90 & 13.3 & 511 & 13.6 & 529 & 12.9 \\
\hline 309.5 & 11.1 & 110 & 13.5 & 528 & 14.2 & 583 & 11.8 \\
\hline 317.5 & 11.8 & 130 & 13.4 & 540 & 14.1 & 652 & 11.7 \\
\hline 345.5 & 12.3 & 150 & 13.8 & 560 & 13.5 & 654 & 10.9 \\
\hline 377.5 & 12.0 & 172 & 14.2 & 580 & 13.1 & 686 & 11.1 \\
\hline 403.5 & 11.8 & 191 & 14.3 & 593 & 13.7 & 687 & 12.4 \\
\hline 417.5 & 11.6 & 198 & 14.2 & 610 & 13.5 & 696 & 13.3 \\
\hline 427.5 & 11.7 & 208 & 13.4 & 625 & 13.2 & 728 & 15.6 \\
\hline 429.5 & 12.1 & 230 & 13.4 & 648 & 13.5 & 728 & 16.2 \\
\hline 437.5 & 12.3 & 253 & 12.8 & 670 & 13.3 & & \\
\hline
\end{tabular}


Table 5. Data from surveys at Hassayampa River near Arlington, Arizona, 1997-2000—Continued

[Values in feet above local datum (see explanation in text). Station locations are distances from left bank. Endpoints for cross-section 8 unrecoverable in 2000]

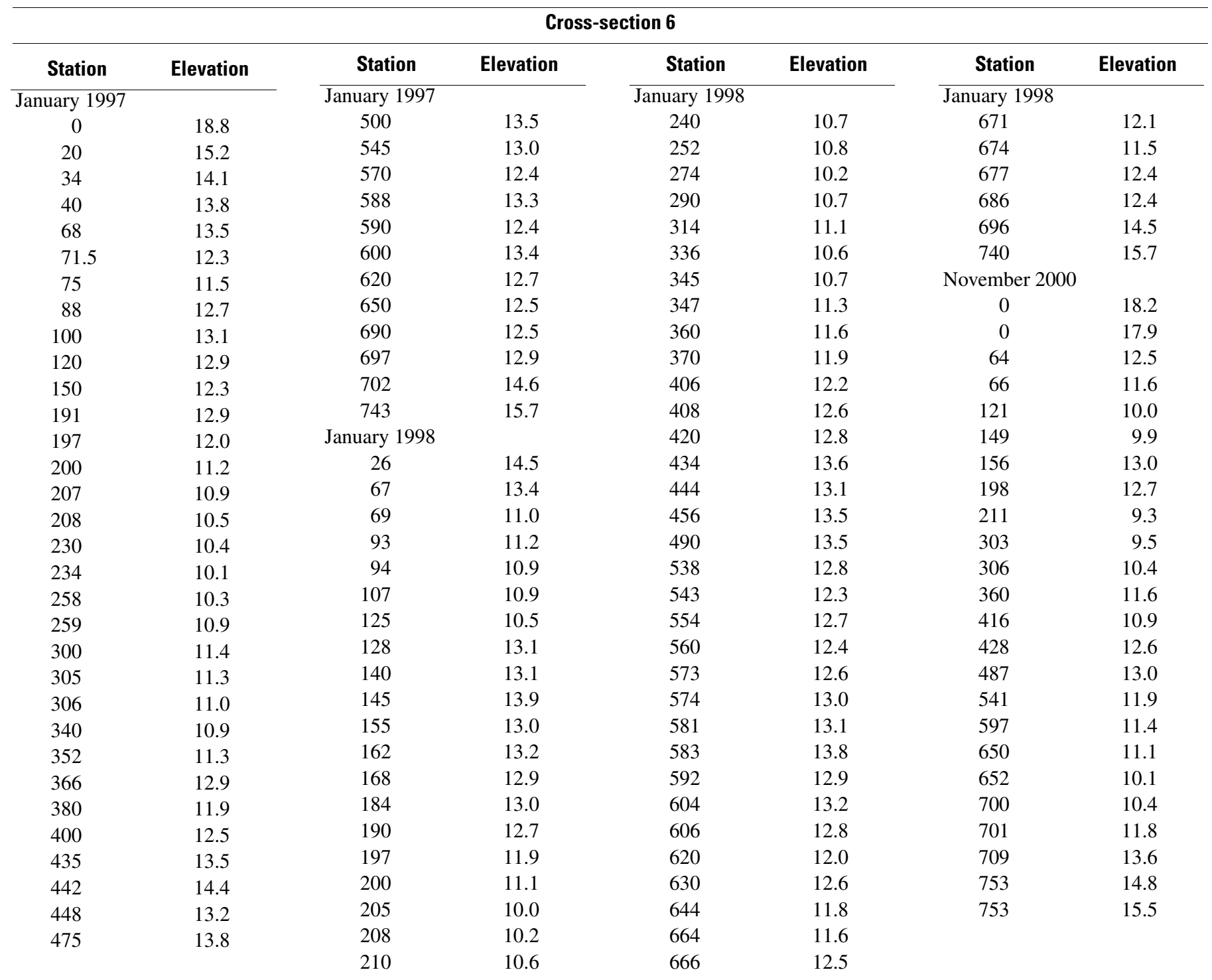




\section{Data from Channel-Change Monitoring at Selected Sites in Maricopa County, Arizona, 1997-2002}

Table 5. Data from surveys at Hassayampa River near Arlington, Arizona, 1997-2000—Continued

[Values in feet above local datum (see explanation in text). Station locations are distances from left bank. Endpoints for cross-section 8 unrecoverable in 2000]

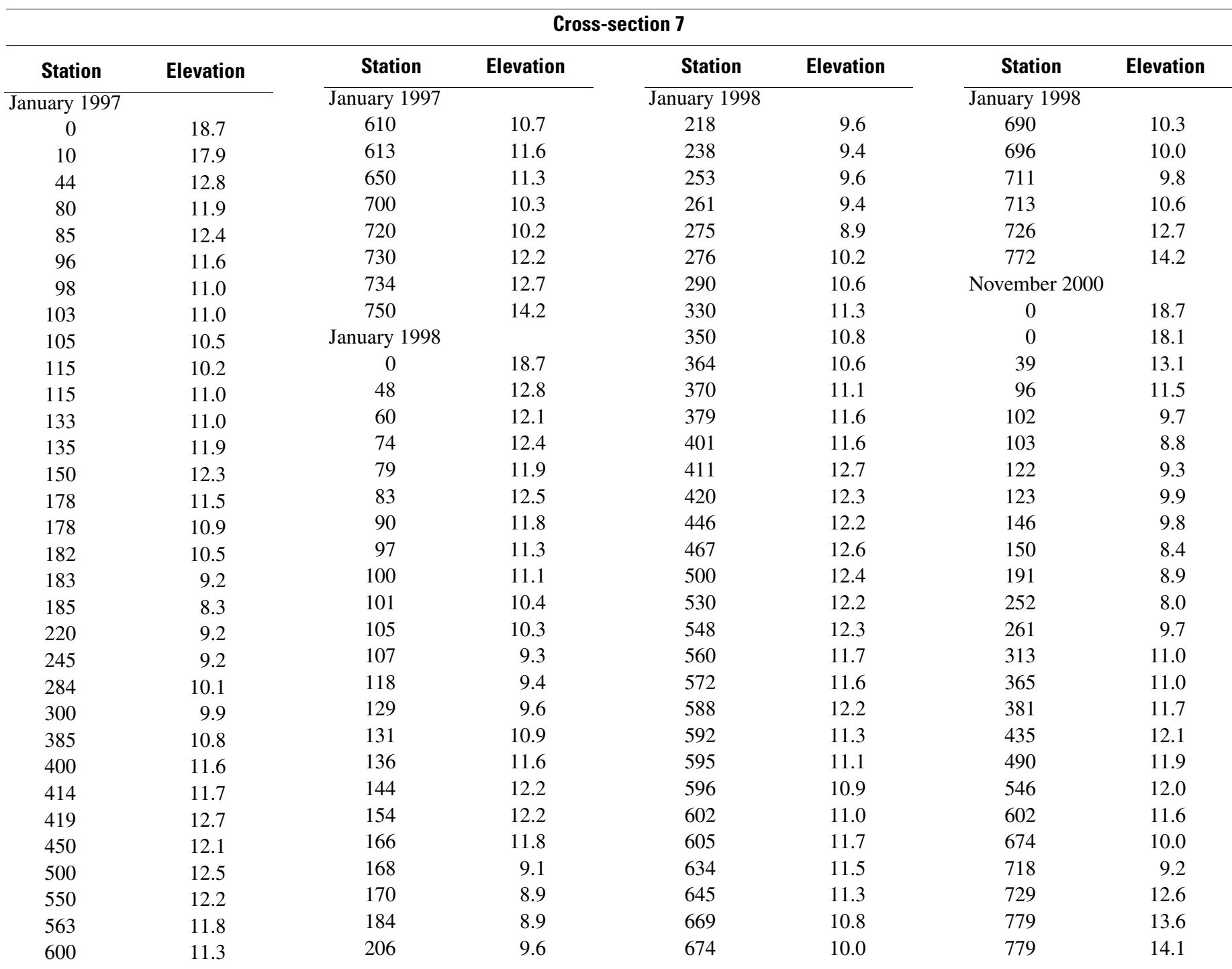


Table 5. Data from surveys at Hassayampa River near Arlington, Arizona, 1997-2000—Continued

[Values in feet above local datum (see explanation in text). Station locations are distances from left bank. Endpoints for cross-section 8 unrecoverable in 2000]

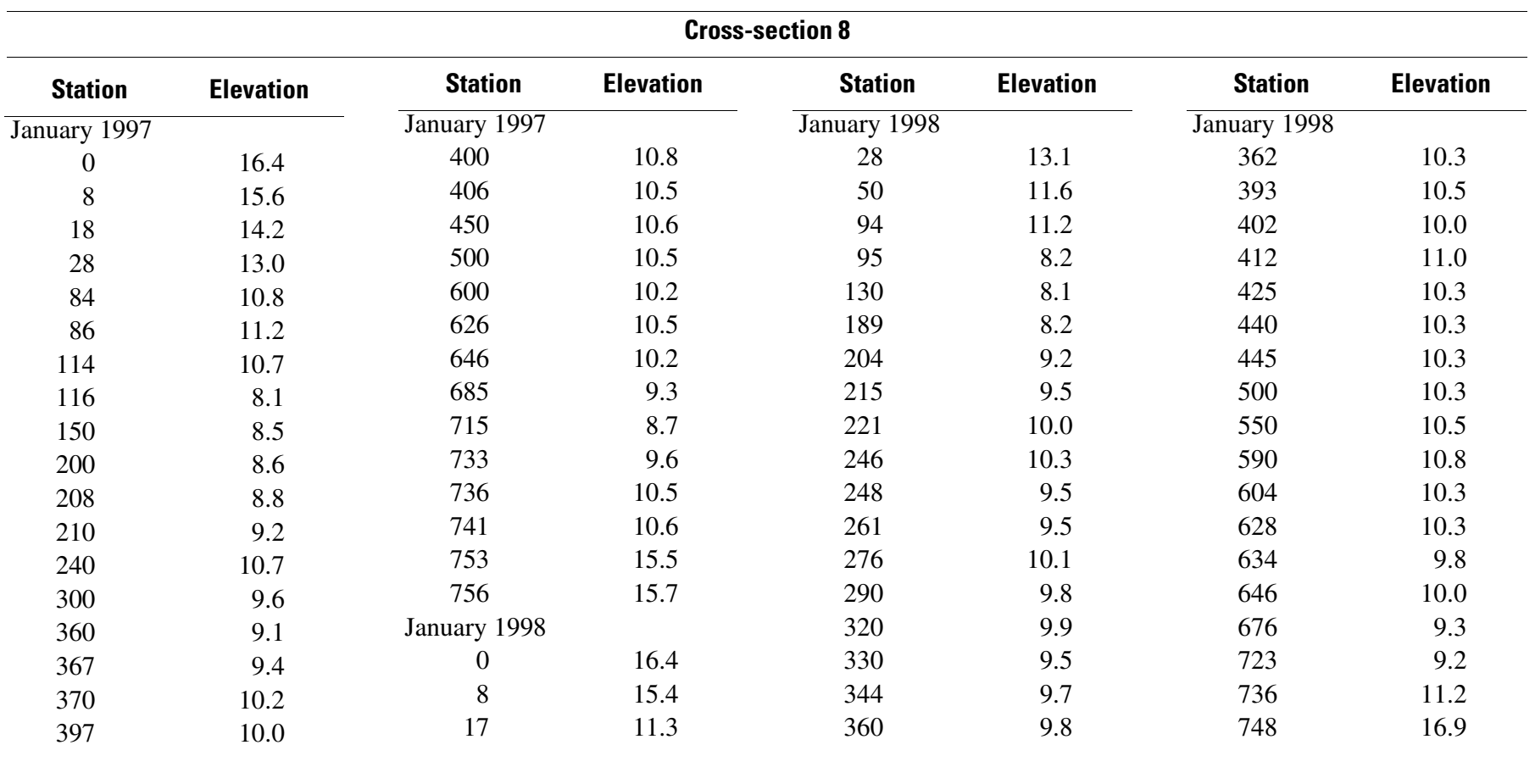

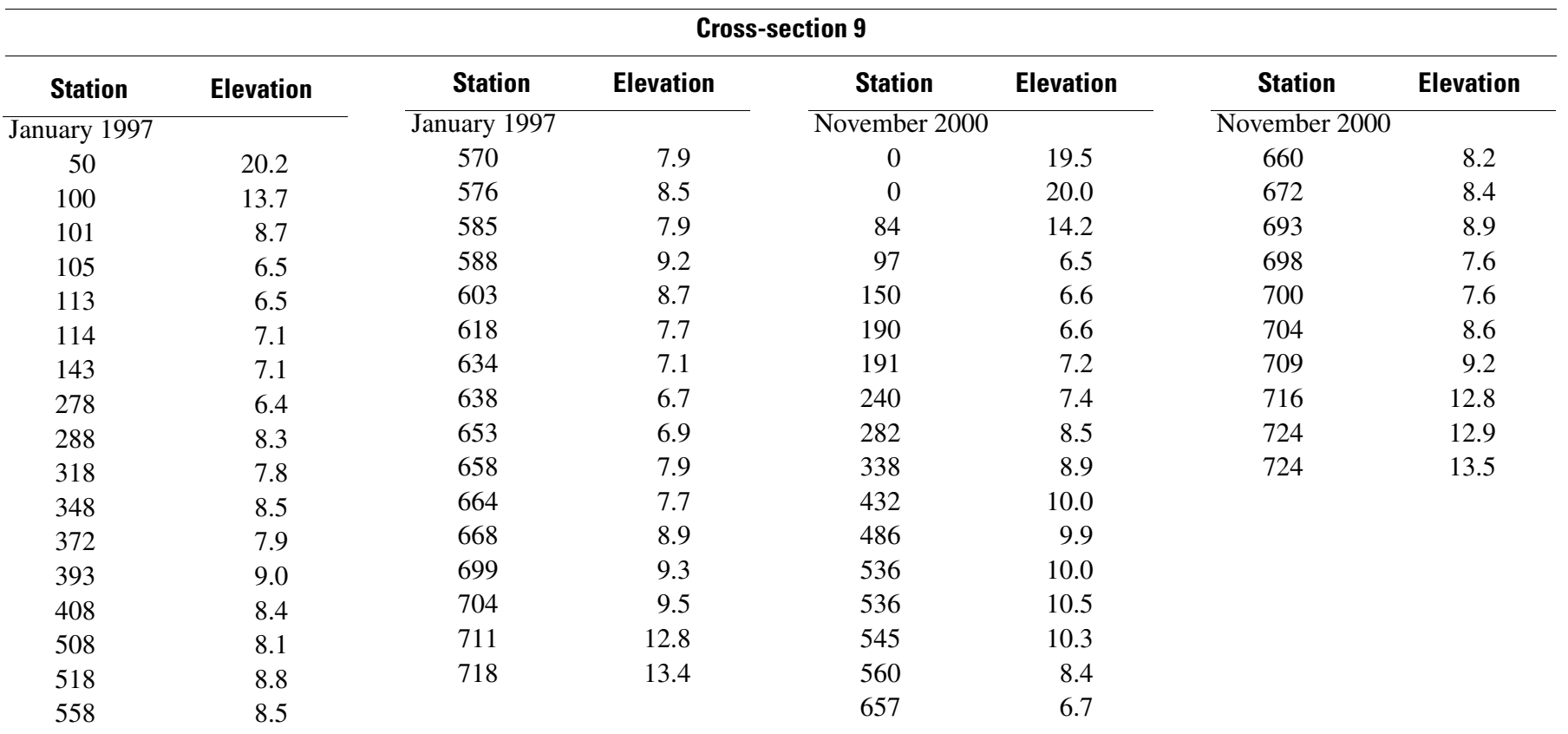


30 Data from Channel-Change Monitoring at Selected Sites in Maricopa County, Arizona, 1997-2002

Table 5. Data from surveys at Hassayampa River near Arlington, Arizona, 1997-2000—Continued

[Values in feet above local datum (see explanation in text). Station locations are distances from left bank. Endpoints for cross-section 8 unrecoverable in 2000]

\begin{tabular}{|c|c|c|c|c|c|c|c|}
\hline \multicolumn{8}{|c|}{ Cross-section 10} \\
\hline Station & Elevation & Station & Elevation & Station & Elevation & Station & Elevation \\
\hline November 2000 & & November 2000 & & November 2000 & & November 2000 & \\
\hline 0 & 18.0 & 224 & 5.6 & 392 & 6.9 & 502 & 7.2 \\
\hline 0 & 17.7 & 292 & 5.3 & 441 & 5.5 & 581 & 11.2 \\
\hline 180 & 7.5 & 292 & 6.0 & 458 & 5.7 & 581 & 11.7 \\
\hline 184 & 5.4 & 348 & 6.6 & 466 & 6.7 & & \\
\hline \multicolumn{8}{|c|}{ Cross-section 11} \\
\hline Station & Elevation & Station & Elevation & Station & Elevation & Station & Elevation \\
\hline November 2000 & & November 2000 & & November 2000 & & November 2000 & \\
\hline 0 & 17.6 & 201 & 6.1 & 373 & 6.1 & 572 & 11.3 \\
\hline 0 & 17.1 & 267 & 5.1 & 419 & 6.6 & 572 & 11.5 \\
\hline 54 & 14.6 & 319 & 4.8 & 474 & 7.6 & & \\
\hline 124 & 10.6 & 372 & 4.9 & 521 & 8.3 & & \\
\hline
\end{tabular}



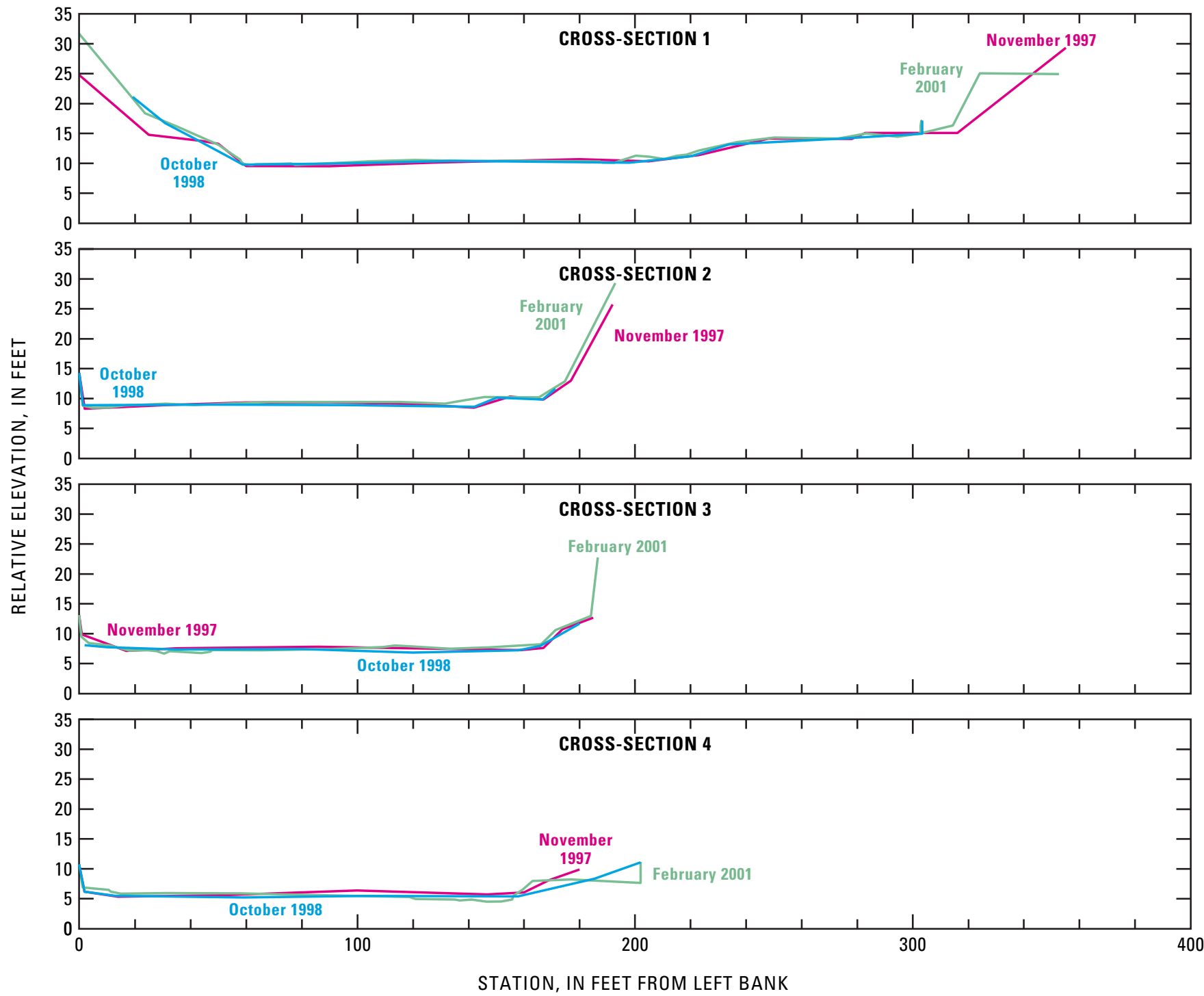

Figure 6. Channel-change cross sections from surveys at Hassayampa River near Morristown, Arizona, 1997-2001. 
Table 6. Data from surveys at Hassayampa River near Morristown, Arizona, 1997-2001

[Values in feet above local datum (see explanation in text). Station locations are distances from left bank]

\begin{tabular}{|c|c|c|c|c|c|c|c|}
\hline \multicolumn{8}{|c|}{ Cross-section 1} \\
\hline Station & Elevation & Station & Elevation & Station & Elevation & Station & Elevation \\
\hline \multicolumn{2}{|c|}{ November 1997} & \multicolumn{2}{|l|}{ October 1998} & \multicolumn{2}{|l|}{ February 2001} & \multicolumn{2}{|l|}{ February 2001} \\
\hline 0 & 24.8 & 19 & 18.9 & 50 & 13.1 & 205 & 11.1 \\
\hline 25 & 14.8 & 31 & 14.6 & 58 & 10.7 & 211 & 10.8 \\
\hline 44 & 13.8 & 43 & 11.7 & 59 & 10.0 & 215 & 11.3 \\
\hline 50 & 13.3 & 54 & 8.9 & 62 & 9.8 & 219 & 11.5 \\
\hline 60 & 9.6 & 59 & 7.6 & 64 & 9.9 & 223 & 12.2 \\
\hline 90 & 9.6 & 95 & 7.8 & 73 & 10.0 & 237 & 13.6 \\
\hline 130 & 10.2 & 135 & 8.2 & 76 & 10.0 & 250 & 14.3 \\
\hline 180 & 10.7 & 198 & 7.9 & 78 & 9.8 & 273 & 14.2 \\
\hline 205 & 10.4 & 220 & 9.0 & 88 & 10.0 & 283 & 15.0 \\
\hline 223 & 11.4 & 234 & 11.0 & 106 & 10.4 & 294 & 14.5 \\
\hline 248 & 14.2 & 273 & 11.9 & 121 & 10.6 & 303 & 15.0 \\
\hline 278 & 14.1 & 303 & 15.0 & 139 & 10.4 & 303 & 17.1 \\
\hline 283 & 15.1 & 303 & 17.2 & 157 & 10.5 & 314 & 16.4 \\
\hline 316 & 15.1 & February 2001 & & 187 & 10.4 & 324 & 25.1 \\
\hline \multirow[t]{3}{*}{355} & 29.3 & 0 & 31.7 & 188 & 10.1 & 353 & 24.9 \\
\hline & & 24 & 18.4 & 192 & 10.1 & & \\
\hline & & 35 & 16.2 & 200 & 11.3 & & \\
\hline
\end{tabular}

\begin{tabular}{|c|c|c|c|c|c|c|c|}
\hline \multicolumn{8}{|c|}{ Cross-section 2} \\
\hline Station & Elevation & Station & Elevation & Station & Elevation & Station & Elevation \\
\hline November 1997 & & October 1998 & & February 2001 & & February 2001 & \\
\hline 0 & 14.3 & 0 & 14.3 & 0 & 14.3 & 138 & 9.7 \\
\hline 2 & 8.3 & 1 & 8.9 & 1 & 8.8 & 146 & 10.3 \\
\hline 30 & 8.9 & 44 & 9.0 & 5 & 8.5 & 165 & 10.2 \\
\hline 60 & 9.4 & 95 & 8.9 & 10 & 8.5 & 175 & 12.9 \\
\hline 90 & 9.4 & 142 & 8.6 & 16 & 8.9 & 193 & 29.3 \\
\hline 120 & 9.1 & 150 & 10.2 & 31 & 9.2 & & \\
\hline 142 & 8.5 & 167 & 9.9 & 41 & 8.9 & & \\
\hline 155 & 10.4 & 171 & 11.7 & 68 & 9.5 & & \\
\hline 167 & 9.9 & & & 94 & 9.5 & & \\
\hline 177 & 13.0 & & & 115 & 9.5 & & \\
\hline 192 & 25.8 & & & 132 & 9.2 & & \\
\hline
\end{tabular}


Table 6. Data from surveys at Hassayampa River near Morristown, Arizona, 1997-2001—Continued

[Values in feet above local datum (see explanation in text). Station locations are distances from left bank]

\begin{tabular}{|c|c|c|c|c|c|c|c|}
\hline \multicolumn{8}{|c|}{ Cross-section 3} \\
\hline Station & Elevation & Station & Elevation & Station & Elevation & Station & Elevation \\
\hline \multicolumn{2}{|c|}{ November 1997} & October 1998 & & \multicolumn{2}{|l|}{ February 2001} & \multicolumn{2}{|l|}{ February 2001} \\
\hline 0 & 13.1 & 2 & 8.1 & 3 & 8.5 & 90 & 7.5 \\
\hline 1 & 9.9 & 10 & 7.8 & 11 & 8.1 & 109 & 7.8 \\
\hline 14 & 7.7 & 35 & 7.4 & 18 & 7.2 & 114 & 8.0 \\
\hline 17 & 7.2 & 80 & 7.5 & 25 & 7.3 & 120 & 7.9 \\
\hline 35 & 7.6 & 120 & 6.9 & 28 & 7.1 & 133 & 7.5 \\
\hline 86 & 7.8 & 158 & 7.2 & 31 & 6.7 & 148 & 7.7 \\
\hline 122 & 7.5 & 166 & 8.0 & 33 & 7.1 & 166 & 8.3 \\
\hline 159 & 7.3 & 180 & 11.7 & 44 & 6.8 & 171 & 10.6 \\
\hline 167 & 7.6 & February 2001 & & 47 & 7.0 & 184 & 13.0 \\
\hline 174 & 10.8 & 0 & 13.1 & 48 & 7.3 & \multirow[t]{2}{*}{187} & \multirow[t]{2}{*}{22.8} \\
\hline 185 & 12.7 & 1 & 9.5 & 66 & 7.2 & & \\
\hline \multicolumn{8}{|c|}{ Cross-section 4} \\
\hline Station & Elevation & Station & Elevation & Station & Elevation & Station & Elevation \\
\hline \multicolumn{2}{|c|}{ November 1997} & October 1998 & & \multicolumn{2}{|l|}{ February 2001} & \multicolumn{2}{|l|}{ February 2001} \\
\hline 0 & 10.8 & 0 & 10.8 & 0 & 10.8 & 137 & 4.7 \\
\hline 2 & 6.2 & 2 & 6.2 & 1 & 6.9 & 141 & 4.9 \\
\hline 14 & 5.4 & 13 & 5.5 & 11 & 6.5 & 147 & 4.6 \\
\hline 50 & 5.6 & 59 & 5.3 & 11 & 6.2 & 152 & 4.6 \\
\hline 100 & 6.4 & 102 & 5.5 & 15 & 5.9 & 156 & 4.9 \\
\hline 147 & 5.8 & 158 & 5.4 & 32 & 6.0 & 157 & 5.6 \\
\hline 160 & 6.1 & 186 & 8.4 & 58 & 5.9 & 160 & 6.5 \\
\hline 169 & 8.1 & 202 & 11.1 & 84 & 5.7 & 163 & 8.0 \\
\hline \multirow[t]{3}{*}{180} & 9.9 & & & 119 & 5.3 & 177 & 8.3 \\
\hline & & & & 121 & 5.0 & 202 & 7.7 \\
\hline & & & & 135 & 4.9 & 202 & 11.2 \\
\hline
\end{tabular}




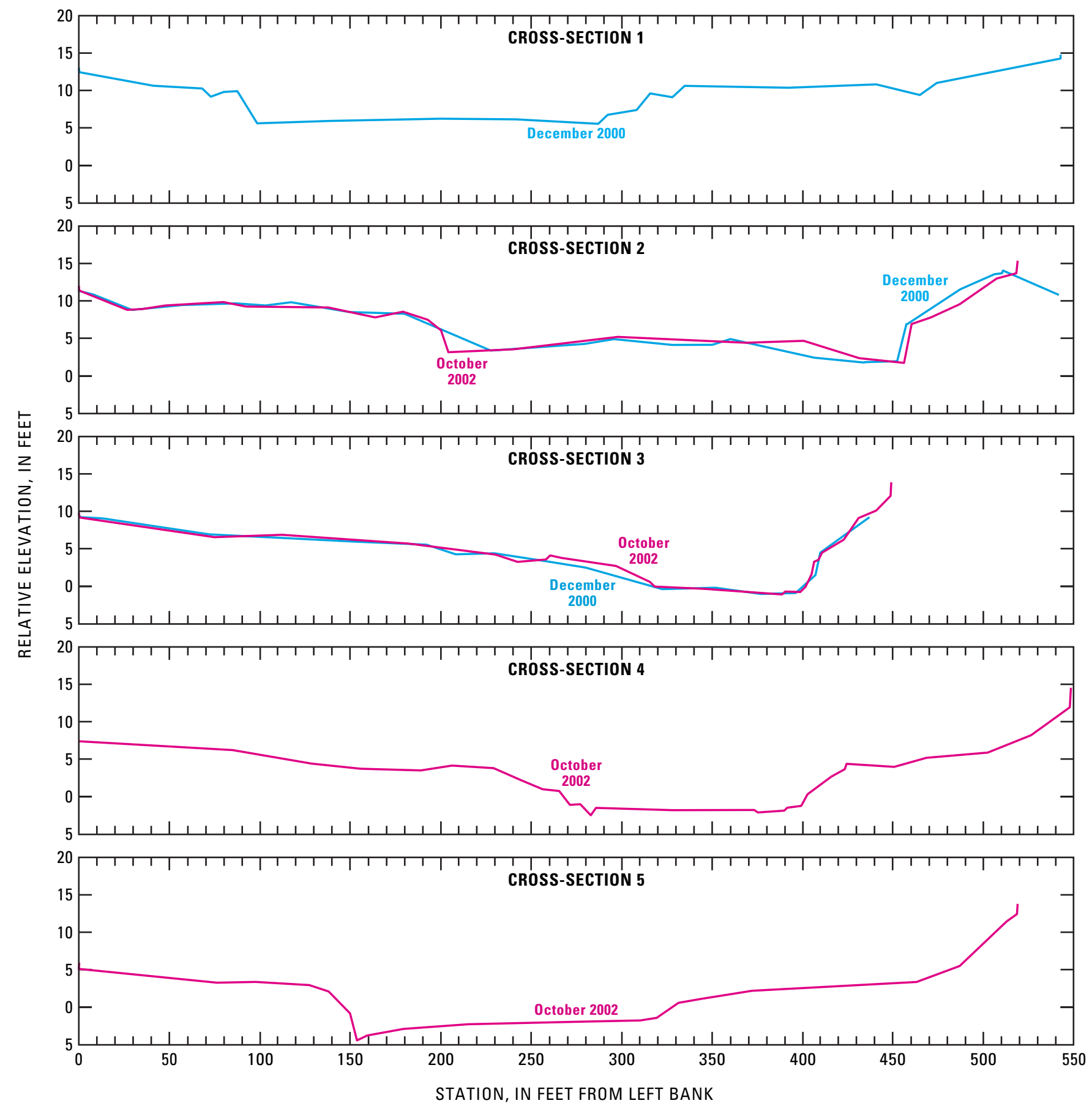

Figure 7. Channel-change cross sections from indirect-measurement surveys at Jackrabbit Wash near Tonopah, Arizona, $2000-2002$. 
Table 7. Data from indirect-measurement surveys at Jackrabbit Wash near Tonopah, Arizona, 2000-2002

[Values in feet above local datum (see explanation in text). Station locations are distances from left bank. Cross-section 1 had no match in 2002, and cross-sections 4 and 5 had no match in 2000]

\begin{tabular}{|c|c|c|c|c|c|c|c|}
\hline \multicolumn{8}{|c|}{ Cross-section 1} \\
\hline Station & Elevation & Station & Elevation & Station & Elevation & Station & Elevation \\
\hline December 2000 & & December 2000 & & December 2000 & & December 2000 & \\
\hline 0 & 13.0 & 88 & 9.9 & 292 & 6.8 & 441 & 10.8 \\
\hline 0 & 12.5 & 99 & 5.6 & 308 & 7.4 & 465 & 9.4 \\
\hline 41 & 10.7 & 139 & 6.0 & 316 & 9.6 & 474 & 11.0 \\
\hline 68 & 10.3 & 200 & 6.3 & 328 & 9.1 & 543 & 14.3 \\
\hline 73 & 9.2 & 242 & 6.2 & 335 & 10.6 & 543 & 14.8 \\
\hline 80 & 9.8 & 287 & 5.6 & 392 & 10.4 & & \\
\hline
\end{tabular}

\begin{tabular}{|c|c|c|c|c|c|c|c|}
\hline \multicolumn{8}{|c|}{ Cross-section 2} \\
\hline Station & Elevation & Station & Elevation & Station & Elevation & Station & Elevation \\
\hline December 2000 & & December 2000 & & October 2002 & & October 2002 & \\
\hline 0 & 11.5 & 350 & 4.2 & 0 & 12.0 & 298 & 5.2 \\
\hline 0 & 11.3 & 360 & 4.9 & 0 & 11.4 & 369 & 4.4 \\
\hline 8 & 10.9 & 377 & 4.0 & 27 & 8.8 & 401 & 4.7 \\
\hline 29 & 8.8 & 407 & 2.4 & 35 & 8.9 & 432 & 2.4 \\
\hline 57 & 9.5 & 434 & 1.8 & 48 & 9.4 & 456 & 1.8 \\
\hline 87 & 9.7 & 435 & 1.9 & 80 & 9.9 & 460 & 6.9 \\
\hline 103 & 9.4 & 452 & 2.0 & 92 & 9.3 & 471 & 7.8 \\
\hline 117 & 9.8 & 458 & 6.9 & 138 & 9.1 & 487 & 9.6 \\
\hline 150 & 8.5 & 458 & 6.9 & 164 & 7.8 & 507 & 13.0 \\
\hline 180 & 8.3 & 487 & 11.6 & 179 & 8.6 & 518 & 13.7 \\
\hline 228 & 3.4 & 506 & 13.6 & 193 & 7.5 & 519 & 15.4 \\
\hline 279 & 4.3 & 510 & 13.7 & 200 & 6.1 & & \\
\hline 296 & 4.9 & 511 & 14.1 & 204 & 3.2 & & \\
\hline 328 & 4.1 & 542 & 10.8 & 240 & 3.6 & & \\
\hline
\end{tabular}




\section{Data from Channel-Change Monitoring at Selected Sites in Maricopa County, Arizona, 1997-2002}

Table 7. Data from indirect-measurement surveys at Jackrabbit Wash near Tonopah, Arizona, 2000-2002-Continued

[Values in feet above local datum (see explanation in text). Station locations are distances from left bank. Cross-section 1 had no match in 2002 , and cross-sections 4 and 5 had no match in 2000]

\begin{tabular}{|c|c|c|c|c|c|c|c|}
\hline \multicolumn{8}{|c|}{ Cross-section 3} \\
\hline Station & Elevation & Station & Elevation & Station & Elevation & Station & Elevation \\
\hline December 2000 & & December 2000 & & October 2002 & & October 2002 & \\
\hline 0 & 9.6 & 323 & -0.4 & 182 & 5.7 & 399 & -0.7 \\
\hline 1 & 9.2 & 352 & -0.2 & 230 & 4.2 & 402 & -0.1 \\
\hline 13 & 9.1 & 377 & -1.0 & 243 & 3.3 & 405 & 1.6 \\
\hline 38 & 8.2 & 396 & -0.9 & 258 & 3.6 & 407 & 3.3 \\
\hline 72 & 6.9 & 407 & 1.5 & 261 & 4.1 & 409 & 3.6 \\
\hline 115 & 6.4 & 410 & 4.5 & 267 & 3.8 & 411 & 4.5 \\
\hline 153 & 6.0 & 437 & 9.2 & 297 & 2.7 & 423 & 6.2 \\
\hline 192 & 5.6 & October 2002 & & 316 & 0.6 & 431 & 9.1 \\
\hline 208 & 4.3 & 0 & 9.8 & 318 & 0.0 & 441 & 10.1 \\
\hline 230 & 4.4 & 0 & 9.2 & 346 & -0.3 & 449 & 12.1 \\
\hline 258 & 3.4 & 75 & 6.6 & 389 & -1.1 & 449 & 13.9 \\
\hline 280 & 2.5 & 112 & 6.9 & 391 & -0.7 & & \\
\hline
\end{tabular}

\begin{tabular}{|c|c|c|c|c|c|c|c|}
\hline \multicolumn{8}{|c|}{ Cross-section 4} \\
\hline Station & Elevation & Station & Elevation & Station & Elevation & Station & Elevation \\
\hline October 2002 & & October 2002 & & October 2002 & & October 2002 & \\
\hline 0 & 7.4 & 244 & 2.2 & 373 & -1.8 & 424 & 4.4 \\
\hline 85 & 6.2 & 256 & 1.0 & 375 & -2.1 & 451 & 4.0 \\
\hline 129 & 4.4 & 266 & 0.8 & 390 & -1.8 & 468 & 5.2 \\
\hline 156 & 3.7 & 271 & -1.1 & 392 & -1.5 & 502 & 5.9 \\
\hline 189 & 3.5 & 277 & -1.0 & 399 & -1.2 & 526 & 8.2 \\
\hline 206 & 4.2 & 283 & -2.5 & 403 & 0.3 & 548 & 11.9 \\
\hline \multirow[t]{2}{*}{229} & 3.8 & 286 & -1.5 & 416 & 2.7 & 548 & 14.5 \\
\hline & & 328 & -1.8 & 423 & 3.7 & & \\
\hline
\end{tabular}

\begin{tabular}{|c|c|c|c|c|c|c|c|}
\hline \multicolumn{8}{|c|}{ Cross-section 5} \\
\hline Station & Elevation & Station & Elevation & Station & Elevation & Station & Elevation \\
\hline October 2002 & & October 2002 & & October 2002 & & October 2002 & \\
\hline 0 & 6.0 & 150 & -0.8 & 311 & -1.7 & 487 & 5.5 \\
\hline 0 & 5.1 & 154 & -4.4 & 320 & -1.4 & 513 & 11.5 \\
\hline 76 & 3.3 & 159 & -3.8 & 332 & 0.6 & 519 & 12.4 \\
\hline 98 & 3.4 & 179 & -2.9 & 344 & 1.1 & 519 & 13.8 \\
\hline 127 & 3.0 & 215 & -2.3 & 372 & 2.2 & & \\
\hline 138 & 2.1 & 280 & -1.9 & 463 & 3.4 & & \\
\hline
\end{tabular}



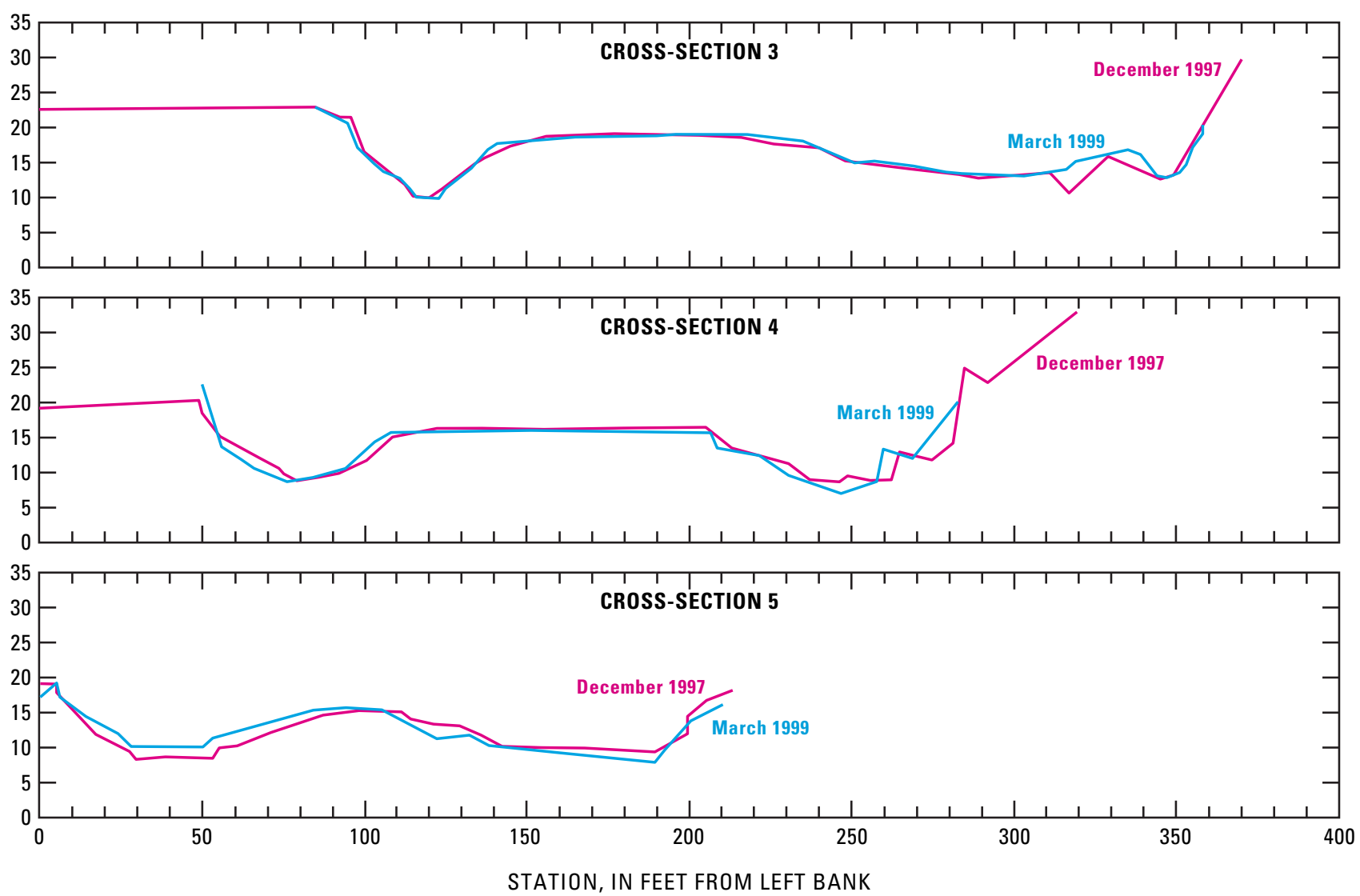

Figure 8. Channel-change cross sections from surveys at New River at New River, Arizona, 1997-99. 
38 Data from Channel-Change Monitoring at Selected Sites in Maricopa County, Arizona, 1997-2002

Table 8. Data from surveys at New River at New River, Arizona, 1997-99

[Values in feet above local datum (see explanation in text). Station locations are distances from left bank]

\begin{tabular}{|c|c|c|c|c|c|c|c|}
\hline \multicolumn{8}{|c|}{ Cross-section 3} \\
\hline Station & Elevation & Station & Elevation & Station & Elevation & Station & Elevation \\
\hline December1997 & & December 1997 & & March 1999 & & March 1999 & \\
\hline 0 & 22.6 & 226 & 17.6 & 103 & 14.9 & 257 & 15.2 \\
\hline 85 & 22.9 & 240 & 17.1 & 106 & 13.7 & 269 & 14.5 \\
\hline 92.5 & 21.5 & 248 & 15.2 & 111 & 12.7 & 279 & 13.6 \\
\hline 96 & 21.5 & 268 & 14.1 & 114 & 11.3 & 284 & 13.4 \\
\hline 100 & 16.5 & 283 & 13.3 & 116 & 10.1 & 303 & 13.1 \\
\hline 112.5 & 11.8 & 289 & 12.8 & 123 & 9.9 & 316 & 14.0 \\
\hline 115 & 10.2 & 311 & 13.5 & 125 & 11.3 & 319 & 15.2 \\
\hline 120 & 9.9 & 317 & 10.6 & 133 & 14.2 & 335 & 16.8 \\
\hline 124 & 11.2 & 329 & 15.9 & 138 & 16.8 & 339 & 16.2 \\
\hline 134 & 14.8 & 345 & 12.6 & 141 & 17.7 & 344 & 13.1 \\
\hline 137 & 15.6 & 349 & 13.2 & 165 & 18.6 & 347 & 12.8 \\
\hline 145 & 17.3 & 370 & 29.7 & 190 & 18.8 & 351 & 13.6 \\
\hline 156 & 18.8 & March 1999 & & 196 & 19.0 & 353 & 14.7 \\
\hline 177 & 19.1 & 85 & 22.9 & 218 & 19.0 & 355 & 17.2 \\
\hline 203 & 18.9 & 95 & 20.6 & 235 & 18.1 & 358 & 19.1 \\
\hline 216 & 18.6 & 98 & 17.1 & 251 & 15.0 & 358 & 20.4 \\
\hline
\end{tabular}

\begin{tabular}{|c|c|c|c|c|c|c|c|}
\hline \multicolumn{8}{|c|}{ Cross-section 4} \\
\hline Station & Elevation & Station & Elevation & Station & Elevation & Station & Elevation \\
\hline December1997 & & December 1997 & & December 1997 & & March 1999 & \\
\hline 0 & 19.2 & 136 & 16.4 & 274 & 11.8 & 103 & 14.4 \\
\hline 49 & 20.3 & 155 & 16.2 & 280.5 & 14.2 & 108 & 15.7 \\
\hline 50 & 18.5 & 179 & 16.4 & 284 & 24.9 & 151 & 16.0 \\
\hline 55.5 & 15.2 & 204.5 & 16.5 & 291 & 22.9 & 206 & 15.7 \\
\hline 67.5 & 12.1 & 212.5 & 13.5 & 318.5 & 33.0 & 208 & 13.5 \\
\hline 73.5 & 10.6 & 230 & 11.3 & March 1999 & & 221 & 12.4 \\
\hline 75 & 9.8 & 236.5 & 9.0 & 50 & 22.6 & 230 & 9.6 \\
\hline 79 & 8.8 & 245.5 & 8.7 & 56 & 13.7 & 246 & 7.0 \\
\hline 86 & 9.4 & 248 & 9.5 & 62 & 11.9 & 257 & 8.7 \\
\hline 92 & 9.9 & 255 & 8.9 & 66 & 10.6 & 259 & 13.4 \\
\hline 100.5 & 11.7 & 261.5 & 9.0 & 76 & 8.7 & 268 & 12.0 \\
\hline 108.5 & 15.1 & 264 & 13.0 & 84 & 9.3 & 282 & 20.1 \\
\hline 122 & 16.3 & 269 & 12.4 & 94 & 10.6 & & \\
\hline
\end{tabular}


Table 8. Data from surveys at New River at New River, Arizona, 1997-99_Continued

[Values in feet above local datum (see explanation in text). Station locations are distances from left bank]

\begin{tabular}{|c|c|c|c|c|c|c|c|}
\hline \multicolumn{8}{|c|}{ Cross-section 5} \\
\hline Station & Elevation & Station & Elevation & Station & Elevation & Station & Elevation \\
\hline December 1997 & & December 1997 & & March 1999 & & March 1999 & \\
\hline 0 & 19.1 & 111 & 15.1 & 0 & 17.2 & 132 & 11.8 \\
\hline 5 & 19.1 & 114 & 14.1 & 5 & 19.2 & 138 & 10.3 \\
\hline 5 & 17.8 & 121 & 13.3 & 6 & 17.2 & 159 & 9.3 \\
\hline 17 & 11.9 & 129 & 13.1 & 14 & 14.4 & 189 & 7.9 \\
\hline 27.5 & 9.4 & 135.5 & 11.8 & 24 & 12.0 & 192 & 9.6 \\
\hline 29.5 & 8.3 & 142 & 10.2 & 28 & 10.1 & 200 & 13.8 \\
\hline 38.5 & 8.6 & 154 & 10.0 & 50 & 10.1 & 210 & 16.1 \\
\hline 53 & 8.5 & 167.5 & 9.9 & 53 & 11.3 & & \\
\hline 55 & 9.9 & 189 & 9.3 & 65 & 12.9 & & \\
\hline 60.5 & 10.2 & 199 & 12.0 & 84 & 15.3 & & \\
\hline 71 & 12.1 & 199 & 14.4 & 94 & 15.7 & & \\
\hline 87 & 14.6 & 205 & 16.7 & 105 & 15.4 & & \\
\hline 98 & 15.3 & 213 & 18.2 & 122 & 11.2 & & \\
\hline
\end{tabular}




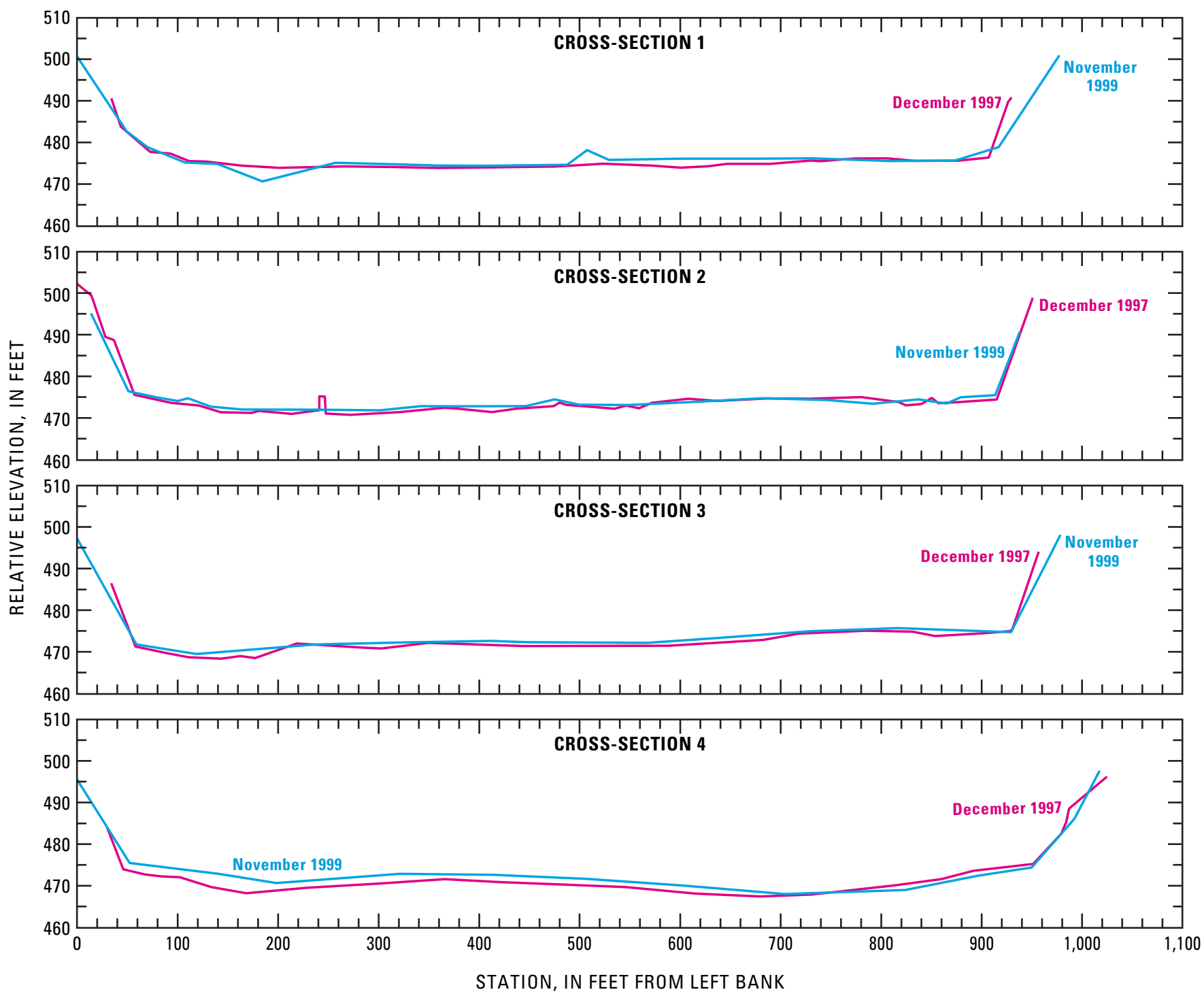

Figure 9. Channel-change cross sections from surveys at Salt River at Priest Drive, near Phoenix, Arizona, 1997-99. 
Table 9. Data from surveys at Salt River at Priest Drive, near Phoenix, Arizona, 1997-99

[Values in feet above local datum (see explanation in text). Station locations are distances from left bank]

\begin{tabular}{|c|c|c|c|c|c|c|c|}
\hline \multicolumn{8}{|c|}{ Cross-section 1} \\
\hline Station & Elevation & Station & Elevation & Station & Elevation & Station & Elevation \\
\hline December1997 & & \multicolumn{2}{|l|}{ December 1997} & \multicolumn{2}{|l|}{ December 1997} & \multicolumn{2}{|l|}{ November 1999} \\
\hline 34 & 490.7 & 475 & 474.3 & 907 & 476.5 & 403 & 474.5 \\
\hline 44 & 483.9 & 524 & 475.0 & 926 & 489.8 & 488 & 474.7 \\
\hline 73 & 477.9 & 572 & 474.5 & 930 & 490.9 & 507 & 478.3 \\
\hline 93 & 477.4 & 601 & 474.0 & November 1999 & & 529 & 475.9 \\
\hline 111 & 475.6 & 628 & 474.4 & 0 & 500.7 & 602 & 476.2 \\
\hline 128 & 475.5 & 647 & 475.0 & 50 & 482.7 & 678 & 476.2 \\
\hline 164 & 474.5 & 689 & 474.9 & 70 & 478.9 & 731 & 476.3 \\
\hline 201 & 474.0 & 730 & 475.8 & 107 & 475.3 & 809 & 475.6 \\
\hline 267 & 474.4 & 740 & 475.6 & 140 & 474.9 & 874 & 475.8 \\
\hline 315 & 474.2 & 774 & 476.2 & 184 & 470.8 & 917 & 479.0 \\
\hline 360 & 474.0 & 806 & 476.3 & 257 & 475.2 & 977 & 501.0 \\
\hline \multirow[t]{2}{*}{414} & 474.1 & 834 & 475.7 & 313 & 474.9 & & \\
\hline & & 876 & 475.7 & 358 & 474.6 & & \\
\hline
\end{tabular}

\begin{tabular}{|c|c|c|c|c|c|c|c|}
\hline \multicolumn{8}{|c|}{ Cross-section 2} \\
\hline Station & Elevation & Station & Elevation & Station & Elevation & Station & Elevation \\
\hline December 1997 & & December 1997 & & December 1997 & & November 1999 & \\
\hline 0 & 502.3 & 321 & 471.5 & 818 & 473.9 & 301 & 471.9 \\
\hline 14 & 499.5 & 366 & 472.6 & 825 & 473.2 & 343 & 473.0 \\
\hline 28 & 489.6 & 379 & 472.3 & 840 & 473.5 & 374 & 472.9 \\
\hline 37 & 488.8 & 413 & 471.5 & 850 & 474.9 & 446 & 472.9 \\
\hline 57 & 475.7 & 437 & 472.3 & 857 & 473.6 & 475 & 474.6 \\
\hline 94 & 473.7 & 474 & 473.0 & 880 & 474.0 & 500 & 473.3 \\
\hline 121 & 473.1 & 480 & 473.8 & 915 & 474.6 & 527 & 473.3 \\
\hline 143 & 471.5 & 487 & 473.3 & 951 & 498.9 & 549 & 473.2 \\
\hline 173 & 471.3 & 535 & 472.4 & November 1999 & & 617 & 474.0 \\
\hline 181 & 471.8 & 546 & 473.1 & 14 & 495.2 & 682 & 474.9 \\
\hline 214 & 471.1 & 559 & 472.4 & 51 & 476.5 & 746 & 474.4 \\
\hline 241 & 472.0 & 572 & 473.8 & 80 & 475.1 & 792 & 473.6 \\
\hline 241 & 475.3 & 608 & 474.7 & 101 & 474.2 & 838 & 474.6 \\
\hline 244 & 475.3 & 637 & 474.2 & 110 & 474.8 & 865 & 473.6 \\
\hline 247 & 475.3 & 687 & 474.8 & 133 & 472.8 & 879 & 475.1 \\
\hline 248 & 471.2 & 729 & 474.7 & 165 & 472.2 & 914 & 475.6 \\
\hline 272 & 470.9 & 780 & 475.1 & 238 & 472.1 & 938 & 490.8 \\
\hline
\end{tabular}


42 Data from Channel-Change Monitoring at Selected Sites in Maricopa County, Arizona, 1997-2002

Table 9. Data from surveys at Salt River at Priest Drive near Phoenix, Arizona, 1997-99_Continued

[Values in feet above local datum (see explanation in text). Station locations are distances from left bank]

\begin{tabular}{|c|c|c|c|c|c|c|c|}
\hline \multicolumn{8}{|c|}{ Cross-section 3} \\
\hline Station & Elevation & Station & Elevation & Station & Elevation & Station & Elevation \\
\hline$\overline{\text { December } 19}$ & & \multicolumn{2}{|c|}{ December 1997} & \multicolumn{2}{|c|}{ December 1997} & \multicolumn{2}{|l|}{ November 1999} \\
\hline 34 & 486.6 & 303 & 470.9 & 902 & 474.5 & 328 & 472.4 \\
\hline 58 & 471.4 & 349 & 472.3 & 929 & 475.1 & 412 & 472.7 \\
\hline 87 & 469.9 & 444 & 471.5 & 931 & 475.6 & 447 & 472.4 \\
\hline 111 & 468.8 & 589 & 471.6 & 957 & 494.1 & 568 & 472.3 \\
\hline 143 & 468.5 & 683 & 473.0 & \multicolumn{2}{|c|}{ November 1999} & 629 & 473.3 \\
\hline 162 & 469.1 & 718 & 474.5 & 0 & 497.3 & 729 & 475.0 \\
\hline 177 & 468.6 & 786 & 475.2 & 59 & 471.9 & 817 & 475.8 \\
\hline 218 & 472.1 & 831 & 474.9 & 119 & 469.6 & 929 & 474.8 \\
\hline 285 & 471.1 & 854 & 473.9 & 238 & 471.9 & 978 & 498.1 \\
\hline \multicolumn{8}{|c|}{ Cross-section 4} \\
\hline Station & Elevation & Station & Elevation & Station & Elevation & Station & Elevation \\
\hline December 19 & & \multicolumn{2}{|c|}{ December 1997} & \multicolumn{2}{|c|}{ December 1997} & \multicolumn{2}{|l|}{ November 1999} \\
\hline 30 & 484.0 & 420 & 471.0 & 979 & 482.5 & 414 & 472.7 \\
\hline 46 & 474.0 & 478 & 470.4 & 984 & 485.2 & 507 & 471.7 \\
\hline 68 & 472.8 & 546 & 469.8 & 987 & 488.5 & 602 & 470.1 \\
\hline 84 & 472.3 & 615 & 468.2 & 1,025 & 496.2 & 704 & 468.1 \\
\hline 102 & 472.1 & 680 & 467.5 & \multicolumn{2}{|c|}{ November 1999} & 824 & 469.1 \\
\hline 134 & 469.8 & 731 & 468.0 & 0 & 495.5 & 897 & 472.5 \\
\hline 169 & 468.3 & 813 & 470.1 & 52 & 475.5 & 950 & 474.4 \\
\hline 229 & 469.6 & 860 & 471.6 & 141 & 472.9 & 992 & 486.1 \\
\hline 301 & 470.6 & 892 & 473.6 & 198 & 470.7 & 1,017 & 497.6 \\
\hline 366 & 471.7 & 951 & 475.3 & 321 & 472.9 & & \\
\hline
\end{tabular}




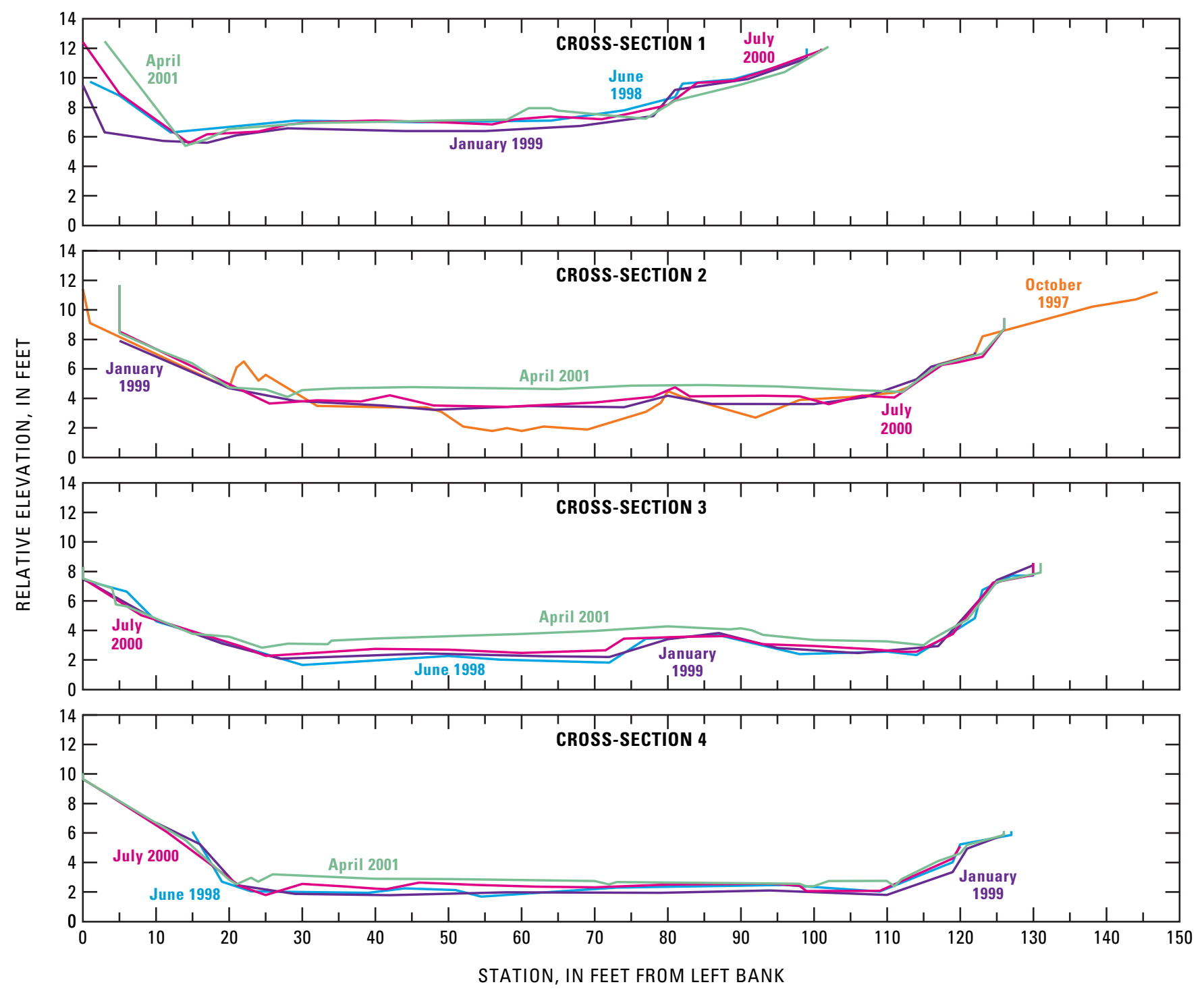

Figure 10. Channel-change cross sections from surveys at Tiger Wash near Aguila, Arizona, 1997-2001. 
Table 10. Data from surveys at Tiger Wash near Aguila, Arizona, 1997-2001

[Values in feet above local datum (see explanation in text). Station locations are distances from left bank]

\begin{tabular}{|c|c|c|c|c|c|c|c|}
\hline \multicolumn{8}{|c|}{ Cross-section 1} \\
\hline Station & Elevation & Station & Elevation & Station & Elevation & Station & Elevation \\
\hline June 1998 & & January 1999 & & July 2000 & & April 2001 & \\
\hline 1 & 9.7 & 28 & 6.6 & 48 & 7.0 & 42 & 7.0 \\
\hline 5 & 8.8 & 44 & 6.4 & 56 & 6.9 & 51 & 7.1 \\
\hline 12 & 6.3 & 55 & 6.4 & 59 & 7.2 & 58 & 7.2 \\
\hline 29 & 7.1 & 68 & 6.7 & 64 & 7.4 & 61 & 8.0 \\
\hline 46 & 7.0 & 78 & 7.4 & 71 & 7.2 & 64 & 8.0 \\
\hline 64 & 7.1 & 81 & 9.2 & 75 & 7.6 & 65 & 7.8 \\
\hline 74 & 7.8 & 91 & 9.9 & 80 & 8.2 & 71 & 7.5 \\
\hline 81 & 8.7 & 99 & 11.3 & 84 & 9.7 & 77 & 7.2 \\
\hline 82 & 9.6 & 99 & 11.4 & 89 & 9.8 & 81 & 8.5 \\
\hline 89 & 9.9 & July 2000 & & 93 & 10.4 & 90 & 9.5 \\
\hline 99 & 11.3 & 0 & 12.4 & 101 & 11.9 & 96 & 10.4 \\
\hline 99 & 12.0 & 5 & 8.9 & 101 & 12.0 & 102 & 12.1 \\
\hline January 1999 & & 15 & 5.6 & April 2001 & & & \\
\hline 0 & 9.5 & 17 & 6.2 & 3 & 12.5 & & \\
\hline 3 & 6.3 & 24 & 6.4 & 14 & 5.4 & & \\
\hline 11 & 5.7 & 28 & 6.8 & 17 & 5.9 & & \\
\hline 17 & 5.6 & 31 & 7.0 & 20 & 6.5 & & \\
\hline 21 & 6.1 & 40 & 7.1 & 31 & 6.9 & & \\
\hline
\end{tabular}

\begin{tabular}{|c|c|c|c|c|c|c|c|}
\hline \multicolumn{8}{|c|}{ Cross-section 2} \\
\hline Station & Elevation & Station & Elevation & Station & Elevation & Station & Elevation \\
\hline June 1998 & & June 1998 & & July 2000 & & April 2001 & \\
\hline 0 & 11.4 & 111 & 4.4 & 5 & 11.7 & 5 & 11.7 \\
\hline 1 & 9.1 & 113 & 4.8 & 5 & 8.5 & 5 & 8.4 \\
\hline 20 & 4.7 & 115 & 5.5 & 26 & 3.7 & 10 & 7.3 \\
\hline 21 & 6.1 & 117 & 6.3 & 32 & 3.9 & 15 & 6.4 \\
\hline 22 & 6.5 & 122 & 7.0 & 38 & 3.8 & 20 & 4.7 \\
\hline 24 & 5.2 & 123 & 8.2 & 42 & 4.2 & 25 & 4.6 \\
\hline 25 & 5.6 & 138 & 10.2 & 48 & 3.5 & 27 & 4.3 \\
\hline 32 & 3.5 & 144 & 10.7 & 58 & 3.4 & 28 & 4.1 \\
\hline 42 & 3.4 & 147 & 11.2 & 70 & 3.7 & 30 & 4.6 \\
\hline 47 & 3.4 & January 1999 & & 78 & 4.1 & 35 & 4.7 \\
\hline 49 & 3.1 & 5 & 7.9 & 81 & 4.8 & 45 & 4.8 \\
\hline 52 & 2.1 & 20 & 4.7 & 83 & 4.1 & 55 & 4.7 \\
\hline 56 & 1.8 & 29 & 3.8 & 93 & 4.2 & 65 & 4.6 \\
\hline 58 & 2.0 & 41 & 3.5 & 98 & 4.1 & 75 & 4.9 \\
\hline 60 & 1.8 & 48 & 3.2 & 102 & 3.6 & 85 & 4.9 \\
\hline 63 & 2.1 & 61 & 3.5 & 107 & 4.2 & 95 & 4.8 \\
\hline 69 & 1.9 & 74 & 3.4 & 111 & 4.1 & 105 & 4.6 \\
\hline 77 & 3.1 & 80 & 4.2 & 118 & 6.3 & 112 & 4.4 \\
\hline 79 & 3.7 & 86 & 3.6 & 120 & 6.4 & 115 & 5.6 \\
\hline 80 & 4.5 & 100 & 3.6 & 123 & 6.8 & 117 & 6.2 \\
\hline 82 & 4.1 & 107 & 4.1 & 126 & 8.7 & 123 & 7.0 \\
\hline 92 & 2.7 & 114 & 5.3 & 126 & 9.5 & 126 & 8.7 \\
\hline 98 & 3.9 & 116 & 6.2 & & & 126 & 9.5 \\
\hline \multirow[t]{2}{*}{105} & 4.1 & 122 & 6.9 & & & & \\
\hline & & 122 & 7.1 & & & & \\
\hline
\end{tabular}


Table 10. Data from surveys at Tiger Wash near Aguila, Arizona, 1997-2001_Continued

[Values in feet above local datum (see explanation in text). Station locations are distances from left bank]

\begin{tabular}{|c|c|c|c|c|c|c|c|}
\hline \multicolumn{8}{|c|}{ Cross-section 3} \\
\hline Station & Elevation & Station & Elevation & Station & Elevation & Station & Elevation \\
\hline June 1998 & & $\begin{array}{l}\text { January } 1999 \\
\end{array}$ & & July 2000 & & April 2001 & \\
\hline 0 & 7.4 & 27 & 2.1 & 72 & 2.7 & 25 & 2.8 \\
\hline 6 & 6.6 & 47 & 2.5 & 74 & 3.5 & 28 & 3.1 \\
\hline 10 & 4.6 & 63 & 2.3 & 82 & 3.6 & 34 & 3.1 \\
\hline 30 & 1.7 & 72 & 2.2 & 88 & 3.6 & 34 & 3.3 \\
\hline 50 & 2.3 & 80 & 3.4 & 93 & 3.1 & 40 & 3.5 \\
\hline 57 & 2.0 & 87 & 3.8 & 100 & 3.0 & 60 & 3.8 \\
\hline 72 & 1.8 & 95 & 2.8 & 108 & 2.7 & 70 & 4.0 \\
\hline 77 & 3.4 & 106 & 2.5 & 112 & 2.6 & 80 & 4.3 \\
\hline 87 & 3.7 & 117 & 2.9 & 114 & 2.6 & 89 & 4.1 \\
\hline 98 & 2.4 & 125 & 7.4 & 119 & 3.8 & 90 & 4.1 \\
\hline 110 & 2.6 & 130 & 8.4 & 125 & 7.2 & 92 & 4.0 \\
\hline 114 & 2.3 & July 2000 & & 130 & 7.8 & 93 & 3.7 \\
\hline 122 & 4.8 & 0 & 8.3 & 130 & 8.6 & 100 & 3.4 \\
\hline 123 & 6.7 & 0 & 7.5 & April 2001 & & 110 & 3.3 \\
\hline 127 & 7.7 & 8 & 5.0 & 0 & 8.3 & 115 & 3.0 \\
\hline 130 & 7.7 & 22 & 2.9 & 0 & 7.5 & 116 & 3.4 \\
\hline 130 & 8.6 & 25 & 2.3 & 4 & 6.9 & 121 & 4.7 \\
\hline January 1999 & & 33 & 2.5 & 5 & 5.8 & 125 & 7.3 \\
\hline 0 & 7.5 & 40 & 2.8 & 6 & 5.6 & 131 & 7.9 \\
\hline 10 & 4.7 & 50 & 2.7 & 15 & 3.8 & 131 & 8.6 \\
\hline 19 & 3.1 & 60 & 2.5 & 20 & 3.6 & & \\
\hline
\end{tabular}

\begin{tabular}{|c|c|c|c|c|c|c|c|}
\hline \multicolumn{8}{|c|}{ Cross-section 4} \\
\hline Station & Elevation & Station & Elevation & Station & Elevation & Station & Elevation \\
\hline June 1998 & & January 1999 & & July 2000 & & April 2001 & \\
\hline 15 & 6.1 & 42 & 1.8 & 42 & 2.2 & 24 & 2.7 \\
\hline 19 & 2.7 & 58 & 2.0 & 46 & 2.6 & 26 & 3.2 \\
\hline 23 & 2.1 & 79 & 2.0 & 54 & 2.5 & 40 & 2.9 \\
\hline 39 & 2.0 & 94 & 2.1 & 62 & 2.4 & 50 & 2.9 \\
\hline 44 & 2.3 & 110 & 1.8 & 70 & 2.3 & 70 & 2.8 \\
\hline 51 & 2.1 & 119 & 3.4 & 80 & 2.5 & 72 & 2.5 \\
\hline 55 & 1.7 & 121 & 5.0 & 94 & 2.6 & 73 & 2.7 \\
\hline 73 & 2.3 & 126 & 5.9 & 98 & 2.4 & 89 & 2.6 \\
\hline 96 & 2.5 & 126 & 6.0 & 99 & 2.1 & 98 & 2.6 \\
\hline 109 & 2.0 & July 2000 & & 109 & 2.1 & 99 & 2.4 \\
\hline 119 & 4.0 & 0 & 10.0 & 119 & 4.3 & 100 & 2.4 \\
\hline 120 & 5.2 & 0 & 9.7 & 120 & 5.1 & 102 & 2.8 \\
\hline 127 & 5.9 & 4 & 8.6 & April 2001 & & 110 & 2.8 \\
\hline 127 & 6.1 & 12 & 6.1 & 0 & 10.1 & 111 & 2.4 \\
\hline January 1999 & & 22 & 2.4 & 0 & 9.7 & 112 & 2.9 \\
\hline 10 & 6.7 & 25 & 1.8 & 9 & 7.0 & 117 & 4.1 \\
\hline 16 & 5.3 & 30 & 2.6 & 14 & 5.5 & 120 & 4.6 \\
\hline 21 & 2.5 & 36 & 2.4 & 20 & 2.8 & 121 & 5.2 \\
\hline \multirow[t]{2}{*}{29} & 1.9 & 40 & 2.2 & 21 & 2.5 & 126 & 5.9 \\
\hline & & & & 23 & 3.0 & 126 & 6.2 \\
\hline
\end{tabular}




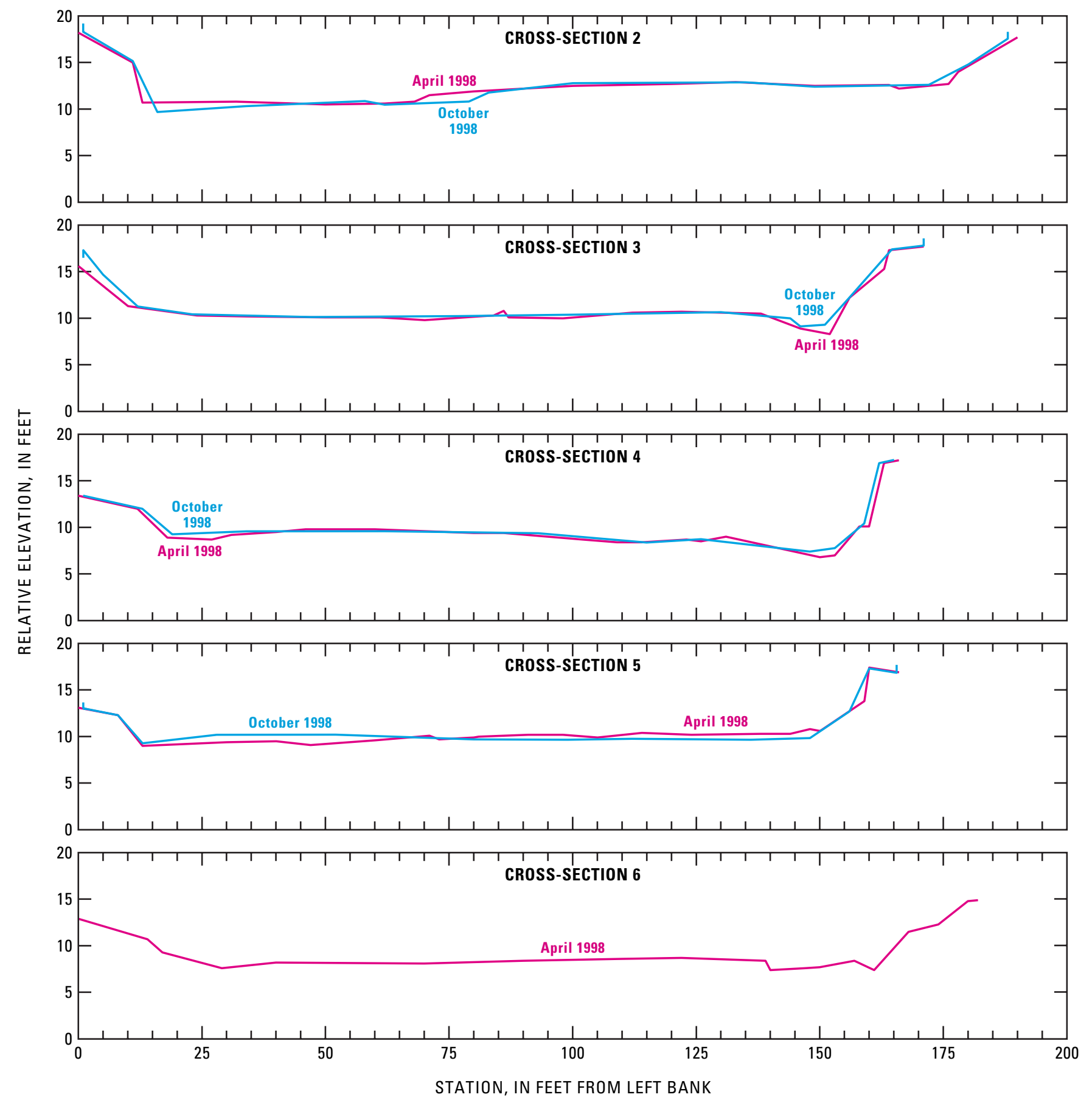

Figure 11. Channel-change cross sections from surveys at Vekol Wash near Stanfield, Arizona, 1998. 
Table 11. Data from surveys at Vekol Wash near Stanfield, Arizona, 1998

[Values in feet above local datum (see explanation in text). Station locations are distances from left bank. Endpoints for cross-section 6 unrecoverable in October 1998]

\begin{tabular}{|c|c|c|c|c|c|c|c|}
\hline \multicolumn{8}{|c|}{ Cross-section 2} \\
\hline Station & Elevation & Station & Elevation & Station & Elevation & Station & Elevation \\
\hline April 1998 & & April 1998 & & October 1998 & & October 1998 & \\
\hline 0 & 18.2 & 100 & 12.5 & 1 & 19.2 & 100 & 12.8 \\
\hline 11 & 15.0 & 120 & 12.7 & 1 & 18.3 & 135 & 12.9 \\
\hline 13 & 10.7 & 133 & 12.9 & 11 & 15.2 & 149 & 12.4 \\
\hline 32 & 10.8 & 149 & 12.5 & 16 & 9.7 & 172 & 12.6 \\
\hline 50 & 10.5 & 164 & 12.6 & 34 & 10.3 & 180 & 14.8 \\
\hline 62 & 10.6 & 166 & 12.2 & 58 & 10.9 & 188 & 17.6 \\
\hline 68 & 10.8 & 176 & 12.7 & 62 & 10.5 & 188 & 18.3 \\
\hline 71 & 11.5 & 178 & 14.0 & 79 & 10.8 & & \\
\hline 80 & 11.9 & 190 & 17.7 & 83 & 11.8 & & \\
\hline
\end{tabular}

\begin{tabular}{|c|c|c|c|c|c|c|c|}
\hline \multicolumn{8}{|c|}{ Cross-section 3} \\
\hline Station & Elevation & Station & Elevation & Station & Elevation & Station & Elevation \\
\hline April 1998 & & April 1998 & & October 1998 & & October 1998 & \\
\hline 0 & 15.6 & 87 & 10.1 & 1 & 16.5 & 151 & 9.3 \\
\hline 10 & 11.3 & 98 & 10.0 & 1 & 17.3 & 156 & 12.2 \\
\hline 24 & 10.3 & 112 & 10.6 & 5 & 14.7 & 165 & 17.4 \\
\hline 34 & 10.2 & 122 & 10.7 & 12 & 11.3 & 171 & 17.8 \\
\hline 50 & 10.1 & 138 & 10.5 & 23 & 10.4 & 171 & 18.6 \\
\hline 61 & 10.1 & 146 & 8.9 & 47 & 10.1 & & \\
\hline 70 & 9.8 & 152 & 8.3 & 77 & 10.2 & & \\
\hline 81 & 10.2 & 156 & 12.2 & 100 & 10.4 & & \\
\hline 84 & 10.3 & 163 & 15.3 & 130 & 10.7 & & \\
\hline \multirow[t]{2}{*}{86} & 10.8 & 164 & 17.3 & 144 & 10.0 & & \\
\hline & & 171 & 17.7 & 146 & 9.1 & & \\
\hline
\end{tabular}

\begin{tabular}{|c|c|c|c|c|c|c|c|}
\hline \multicolumn{8}{|c|}{ Cross-section 4} \\
\hline Station & Elevation & Station & Elevation & Station & Elevation & Station & Elevation \\
\hline April 1998 & & April 1998 & & April 1998 & & October 1998 & \\
\hline 0 & 13.4 & 86 & 9.4 & 158 & 10.1 & 62 & 9.6 \\
\hline 12 & 12.0 & 102 & 8.7 & 160 & 10.1 & 93 & 9.4 \\
\hline 18 & 8.9 & 109 & 8.4 & 163 & 16.9 & 115 & 8.4 \\
\hline 27 & 8.7 & 114 & 8.4 & 166 & 17.2 & 126 & 8.7 \\
\hline 31 & 9.2 & 123 & 8.7 & October 1998 & & 148 & 7.4 \\
\hline 40 & 9.5 & 126 & 8.5 & 1 & 13.4 & 153 & 7.8 \\
\hline 46 & 9.8 & 131 & 9.0 & 13 & 12.0 & 159 & 10.4 \\
\hline 60 & 9.8 & 150 & 6.8 & 19 & 9.3 & 162 & 16.9 \\
\hline 80 & 9.4 & 153 & 7.0 & 34 & 9.6 & 165 & 17.2 \\
\hline
\end{tabular}


Table 11. Data from surveys at Vekol Wash near Stanfield, Arizona, 1998_Continued

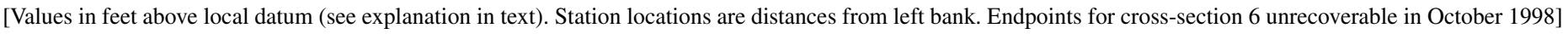

\begin{tabular}{|c|c|c|c|c|c|c|c|}
\hline \multicolumn{8}{|c|}{ Cross-section 5} \\
\hline Station & Elevation & Station & Elevation & Station & Elevation & Station & Elevation \\
\hline April 1998 & & April 1998 & & April 1998 & & October 1998 & \\
\hline 0 & 13.1 & 80 & 9.9 & 150 & 10.6 & 52 & 10.2 \\
\hline 8 & 12.3 & 81 & 10.0 & 159 & 13.8 & 80 & 9.7 \\
\hline 13 & 9.0 & 91 & 10.2 & 160 & 17.4 & 99 & 9.7 \\
\hline 30 & 9.4 & 98 & 10.2 & 166 & 16.9 & 112 & 9.8 \\
\hline 40 & 9.5 & 105 & 9.9 & October 1998 & & 136 & 9.7 \\
\hline 47 & 9.1 & 114 & 10.4 & 1 & 13.7 & 148 & 9.8 \\
\hline 60 & 9.6 & 124 & 10.2 & 1 & 13.0 & 156 & 12.7 \\
\hline 71 & 10.1 & 138 & 10.3 & 8 & 12.3 & 160 & 17.3 \\
\hline \multirow[t]{2}{*}{73} & 9.7 & 144 & 10.3 & 13 & 9.3 & 166 & 16.9 \\
\hline & & 148 & 10.8 & 28 & 10.2 & 166 & 17.7 \\
\hline \multicolumn{8}{|c|}{ Cross-section 6} \\
\hline Station & Elevation & Station & Elevation & Station & Elevation & Station & Elevation \\
\hline April 1998 & & April 1998 & & April 1998 & & April 1998 & \\
\hline 0 & 12.7 & 40 & 8.2 & 139 & 8.4 & 161 & 7.4 \\
\hline 14 & 10.7 & 70 & 8.1 & 140 & 7.4 & 168 & 11.5 \\
\hline 17 & 9.3 & 90 & 8.4 & 147 & 7.6 & 174 & 12.3 \\
\hline \multirow[t]{2}{*}{29} & 7.6 & 110 & 8.6 & 150 & 7.7 & 180 & 14.8 \\
\hline & & 122 & 8.7 & 157 & 8.4 & 182 & 14.9 \\
\hline
\end{tabular}




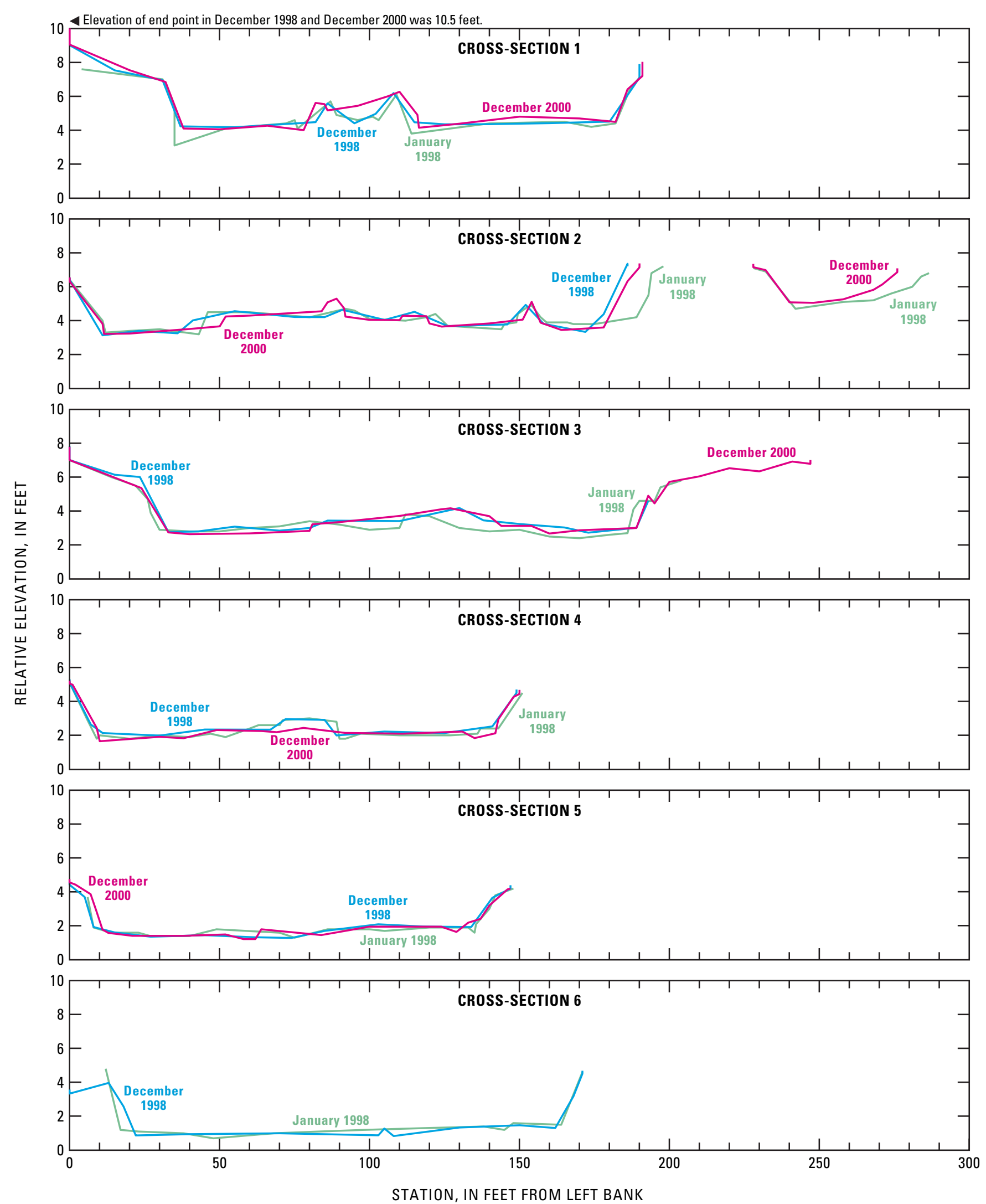

Figure 12. Channel-change cross sections from surveys at Waterman Wash near Buckeye, Arizona, 1997-2000. 
50 Data from Channel-Change Monitoring at Selected Sites in Maricopa County, Arizona, 1997-2002

Table 12. Data from surveys at Waterman Wash near Buckeye, Arizona, 1997-2000

[Values in feet above local datum (see explanation in text). Station locations are distances from left bank]

\begin{tabular}{|c|c|c|c|c|c|c|c|}
\hline \multicolumn{8}{|c|}{ Cross-section 1} \\
\hline Station & Elevation & Station & Elevation & Station & Elevation & Station & Elevation \\
\hline January 1998 & & January 1998 & & December 1998 & & December 2000 & \\
\hline 4 & 7.6 & 165 & 4.5 & 115 & 4.5 & 85 & 5.5 \\
\hline 31 & 7.0 & 174 & 4.2 & 125 & 4.4 & 86 & 5.2 \\
\hline 35 & 5.4 & 182 & 4.4 & 140 & 4.4 & 96 & 5.4 \\
\hline 35 & 3.1 & 187 & 6.5 & 160 & 4.4 & 106 & 6.0 \\
\hline 52 & 4.1 & 190 & 7.1 & 180 & 4.5 & 110 & 6.3 \\
\hline 72 & 4.4 & December 1998 & & 190 & 7.1 & 116 & 4.9 \\
\hline 75 & 4.6 & 0 & 10.5 & 190 & 7.9 & 117 & 4.2 \\
\hline 76 & 4.1 & 0 & 9.0 & December 2000 & & 130 & 4.4 \\
\hline 87 & 5.7 & 15 & 7.5 & 0 & 10.5 & 150 & 4.8 \\
\hline 89 & 4.9 & 31 & 7.0 & 0 & 9.1 & 170 & 4.7 \\
\hline 96 & 4.6 & 37 & 4.2 & 20 & 7.5 & 182 & 4.5 \\
\hline 101 & 4.8 & 55 & 4.2 & 32 & 6.8 & 186 & 6.4 \\
\hline 103 & 4.6 & 82 & 4.5 & 38 & 4.1 & 191 & 7.2 \\
\hline 109 & 6.1 & 86 & 5.6 & 50 & 4.1 & 191 & 8.0 \\
\hline 114 & 3.8 & 95 & 4.4 & 66 & 4.3 & & \\
\hline \multirow[t]{2}{*}{140} & 4.4 & 102 & 5.0 & 78 & 4.0 & & \\
\hline & & 108 & 6.2 & 82 & 5.6 & & \\
\hline
\end{tabular}

\begin{tabular}{|c|c|c|c|c|c|c|c|}
\hline \multicolumn{8}{|c|}{ Cross-section 2} \\
\hline Station & Elevation & Station & Elevation & Station & Elevation & Station & Elevation \\
\hline January 1998 & & January 1998 & & December 1998 & & December 2000 & \\
\hline 0 & 6.4 & 154 & 4.9 & 105 & 4.1 & 84 & 4.6 \\
\hline 11 & 4.0 & 157 & 4.2 & 115 & 4.5 & 86 & 5.1 \\
\hline 12 & 3.3 & 159 & 3.9 & 126 & 3.7 & 89 & 5.3 \\
\hline 20 & 3.4 & 166 & 3.9 & 146 & 3.8 & 92 & 4.7 \\
\hline 30 & 3.5 & 168 & 3.8 & 152 & 4.9 & 92 & 4.2 \\
\hline 43 & 3.2 & 175 & 3.8 & 158 & 3.8 & 100 & 4.1 \\
\hline 46 & 4.5 & 189 & 4.2 & 172 & 3.3 & 110 & 4.0 \\
\hline 60 & 4.5 & 193 & 5.5 & 178 & 4.4 & 111 & 4.3 \\
\hline 80 & 4.2 & 194 & 6.8 & 186 & 7.2 & 119 & 4.3 \\
\hline 92 & 4.7 & 198 & 7.2 & 186 & 7.4 & 120 & 3.8 \\
\hline 95 & 4.6 & December 1998 & & December 2000 & & 124 & 3.7 \\
\hline 100 & 4.1 & 0 & 6.6 & 0 & 6.6 & 140 & 3.8 \\
\hline 112 & 4.0 & 0 & 6.4 & 0 & 6.3 & 151 & 4.1 \\
\hline 119 & 4.2 & 11 & 3.1 & 11 & 3.8 & 154 & 5.1 \\
\hline 122 & 4.4 & 23 & 3.4 & 12 & 3.2 & 157 & 3.9 \\
\hline 126 & 3.7 & 36 & 3.3 & 20 & 3.2 & 164 & 3.5 \\
\hline 144 & 3.5 & 41 & 4.0 & 30 & 3.4 & 178 & 3.6 \\
\hline 145 & 3.8 & 55 & 4.6 & 40 & 3.5 & 186 & 6.3 \\
\hline 149 & 3.9 & 75 & 4.2 & 50 & 3.7 & 190 & 7.1 \\
\hline 150 & 4.4 & 85 & 4.2 & 52 & 4.3 & 190 & 7.4 \\
\hline 153 & 4.8 & 91 & 4.6 & 60 & 4.3 & & \\
\hline
\end{tabular}


Table 12. Data from surveys at Waterman Wash near Buckeye, Arizona, 1997-2000—Continued

[Values in feet above local datum (see explanation in text). Station locations are distances from left bank]

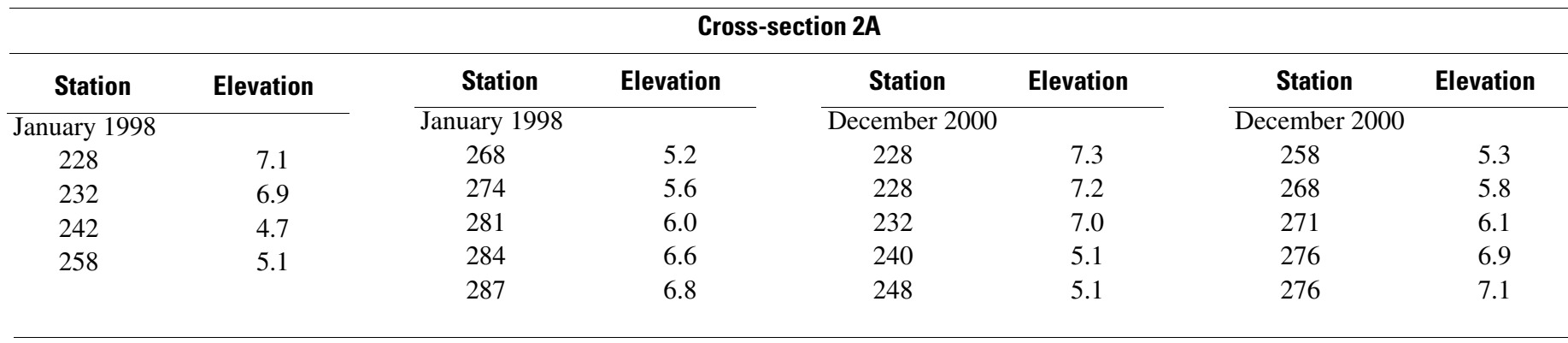

\begin{tabular}{|c|c|c|c|c|c|c|c|}
\hline \multicolumn{8}{|c|}{ Cross-section 3} \\
\hline Station & Elevation & Station & Elevation & Station & Elevation & Station & Elevation \\
\hline January 1998 & & January 1998 & & December 1998 & & December 2000 & \\
\hline 0 & 7.0 & 150 & 2.9 & 80 & 3.0 & 90 & 3.4 \\
\hline 14 & 6.0 & 160 & 2.5 & 86 & 3.4 & 110 & 3.7 \\
\hline 22 & 5.5 & 170 & 2.4 & 110 & 3.4 & 124 & 4.1 \\
\hline 26 & 4.7 & 180 & 2.6 & 130 & 4.2 & 127 & 4.2 \\
\hline 27 & 3.9 & 186 & 2.7 & 138 & 3.5 & 140 & 3.7 \\
\hline 30 & 2.9 & 188 & 4.1 & 150 & 3.2 & 144 & 3.1 \\
\hline 40 & 2.8 & 190 & 4.6 & 165 & 3.0 & 154 & 3.1 \\
\hline 50 & 2.8 & 195 & 4.6 & 173 & 2.7 & 160 & 2.7 \\
\hline 60 & 3.0 & 197 & 5.4 & 189 & 3.0 & 170 & 2.9 \\
\hline 70 & 3.1 & 204 & 5.8 & 193 & 4.6 & 189 & 3.0 \\
\hline 80 & 3.4 & December 1998 & & December 2000 & & 193 & 4.9 \\
\hline 90 & 3.2 & 0 & 7.8 & 0 & 7.8 & 195 & 4.5 \\
\hline 100 & 2.9 & 0 & 7.0 & 0 & 7.0 & 200 & 5.7 \\
\hline 110 & 3.0 & 15 & 6.1 & 24 & 5.4 & 210 & 6.0 \\
\hline 112 & 3.8 & 24 & 6.0 & 33 & 2.7 & 220 & 6.5 \\
\hline 120 & 3.7 & 33 & 2.8 & 40 & 2.6 & 230 & 6.3 \\
\hline 130 & 3.0 & 43 & 2.8 & 60 & 2.7 & 241 & 6.9 \\
\hline 140 & 2.8 & 55 & 3.1 & 80 & 2.8 & 247 & 6.8 \\
\hline & & 70 & 2.8 & 81 & 3.2 & 247 & 7.0 \\
\hline
\end{tabular}


Table 12. Data from surveys at Waterman Wash near Buckeye, Arizona, 1997-2000_Continued

[Values in feet above local datum (see explanation in text). Station locations are distances from left bank]

\begin{tabular}{|c|c|c|c|c|c|c|c|}
\hline \multicolumn{8}{|c|}{ Cross-section 4} \\
\hline Station & Elevation & Station & Elevation & Station & Elevation & Station & Elevation \\
\hline January 1998 & & 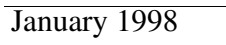 & & December 1998 & & December 2000 & \\
\hline 0 & 5.1 & 90 & 1.8 & 67 & 2.3 & 38 & 1.8 \\
\hline 6 & 2.9 & 92 & 1.8 & 72 & 3.0 & 49 & 2.3 \\
\hline 9 & 1.8 & 97 & 2.1 & 85 & 2.9 & 64 & 2.3 \\
\hline 10 & 2.0 & 110 & 2.0 & 89 & 2.0 & 69 & 2.2 \\
\hline 20 & 1.8 & 127 & 2.0 & 105 & 2.2 & 78 & 2.4 \\
\hline 30 & 2.0 & 136 & 2.1 & 125 & 2.1 & 92 & 2.1 \\
\hline 40 & 1.9 & 137 & 2.4 & 141 & 2.5 & 111 & 2.1 \\
\hline 47 & 2.1 & 143 & 2.4 & 149 & 4.5 & 131 & 2.2 \\
\hline 52 & 1.9 & 151 & 4.5 & 149 & 4.7 & 135 & 1.8 \\
\hline 60 & 2.4 & December 1998 & & December 2000 & & 142 & 2.1 \\
\hline 63 & 2.6 & 0 & 5.3 & 0 & 5.2 & 143 & 2.9 \\
\hline 70 & 2.6 & 0 & 5.1 & 0 & 5.0 & 148 & 4.3 \\
\hline 71 & 2.9 & 7 & 2.6 & 1 & 5.0 & 150 & 4.4 \\
\hline 80 & 3.0 & 11 & 2.1 & 9 & 2.4 & 150 & 4.7 \\
\hline \multirow[t]{2}{*}{89} & 2.8 & 30 & 2.0 & 10 & 1.7 & & \\
\hline & & 45 & 2.3 & 30 & 1.9 & & \\
\hline
\end{tabular}

\begin{tabular}{|c|c|c|c|c|c|c|c|}
\hline \multicolumn{8}{|c|}{ Cross-section 5} \\
\hline Station & Elevation & Station & Elevation & Station & Elevation & Station & Elevation \\
\hline January 1998 & & January 1998 & & December 1998 & & December 2000 & \\
\hline 6 & 3.7 & 135 & 1.6 & 85 & 1.7 & 21 & 1.4 \\
\hline 8 & 1.9 & 136 & 2.1 & 103 & 2.1 & 38 & 1.4 \\
\hline 14 & 1.6 & 140 & 3.0 & 118 & 2.0 & 52 & 1.5 \\
\hline 23 & 1.6 & 142 & 3.8 & 134 & 1.9 & 58 & 1.2 \\
\hline 27 & 1.4 & 148 & 4.2 & 141 & 3.7 & 62 & 1.2 \\
\hline 40 & 1.4 & December 1998 & & 147 & 4.2 & 64 & 1.8 \\
\hline 49 & 1.8 & 0 & 4.6 & 147 & 4.4 & 84 & 1.5 \\
\hline 70 & 1.6 & 0 & 4.4 & December 2000 & & 100 & 2.0 \\
\hline 75 & 1.3 & 5 & 3.7 & 0 & 4.8 & 124 & 2.0 \\
\hline 86 & 1.8 & 8 & 1.9 & 0 & 4.6 & 129 & 1.6 \\
\hline 100 & 1.8 & 15 & 1.6 & 2 & 4.4 & 133 & 2.2 \\
\hline 105 & 1.7 & 27 & 1.4 & 7 & 3.9 & 137 & 2.4 \\
\hline 120 & 1.9 & 45 & 1.5 & 9 & 2.9 & 140 & 3.2 \\
\hline 130 & 1.9 & 61 & 1.3 & 11 & 1.8 & 146 & 4.2 \\
\hline 133 & 1.9 & 74 & 1.3 & 13 & 1.6 & 147 & 4.2 \\
\hline \multicolumn{8}{|c|}{ Cross-section 6} \\
\hline Station & Elevation & Station & Elevation & Station & Elevation & Station & Elevation \\
\hline January 1998 & & January 1998 & & December 2000 & & December 2000 & \\
\hline 12 & 4.8 & 118 & 1.3 & 0 & 3.3 & 108 & 0.8 \\
\hline 17 & 1.2 & 138 & 1.4 & 13 & 4.0 & 130 & 1.3 \\
\hline 23 & 1.1 & 145 & 1.2 & 18 & 2.6 & 150 & 1.5 \\
\hline 38 & 1.0 & 148 & 1.6 & 22 & 0.9 & 162 & 1.3 \\
\hline 48 & 0.7 & 164 & 1.5 & 40 & 1.0 & 168 & 3.2 \\
\hline 68 & 1.0 & 171 & 4.6 & 70 & 1.0 & 171 & 4.5 \\
\hline 83 & 1.1 & December 2000 & & 103 & 0.9 & 171 & 4.7 \\
\hline 98 & 1.2 & 0 & 3.6 & 105 & 1.3 & & \\
\hline
\end{tabular}


Manuscript approved for publication, May 19, 2004

Prepared by U.S. Geological Survey Publishing staff

Arizona District, Tucson, Arizona:

Sid Alwin

Steve Longsworth

Washington Water Science Center, Tacoma, Washington: Linda Rogers

For more information concerning the research in this report, contact the District Chief, Water Resources Discipline

U.S. Geological Survey, 520 N. Park Avenue, Suite 221

Tucson, Arizona 85719-5035

http://az.water.usgs.gov 
